WHC-EP-0669

\title{
Ferrocyanide Safety Program: Updated Thermal Analysis Model for Ferrocyanide Tanks with Application to Tank 241-BY-104
}

J. M. McLaren

Date Published

December 1993

Prepared for the U.S. Department of Energy Office of Environmental Restoration and Waste Management

\section{(W) Westinghouse Hanford Company Richland, Washington 99352}

Hanford Operations and Engineering Contractor for the

U.S. Department of Energy under Contract DE.AC06.87RL10930 


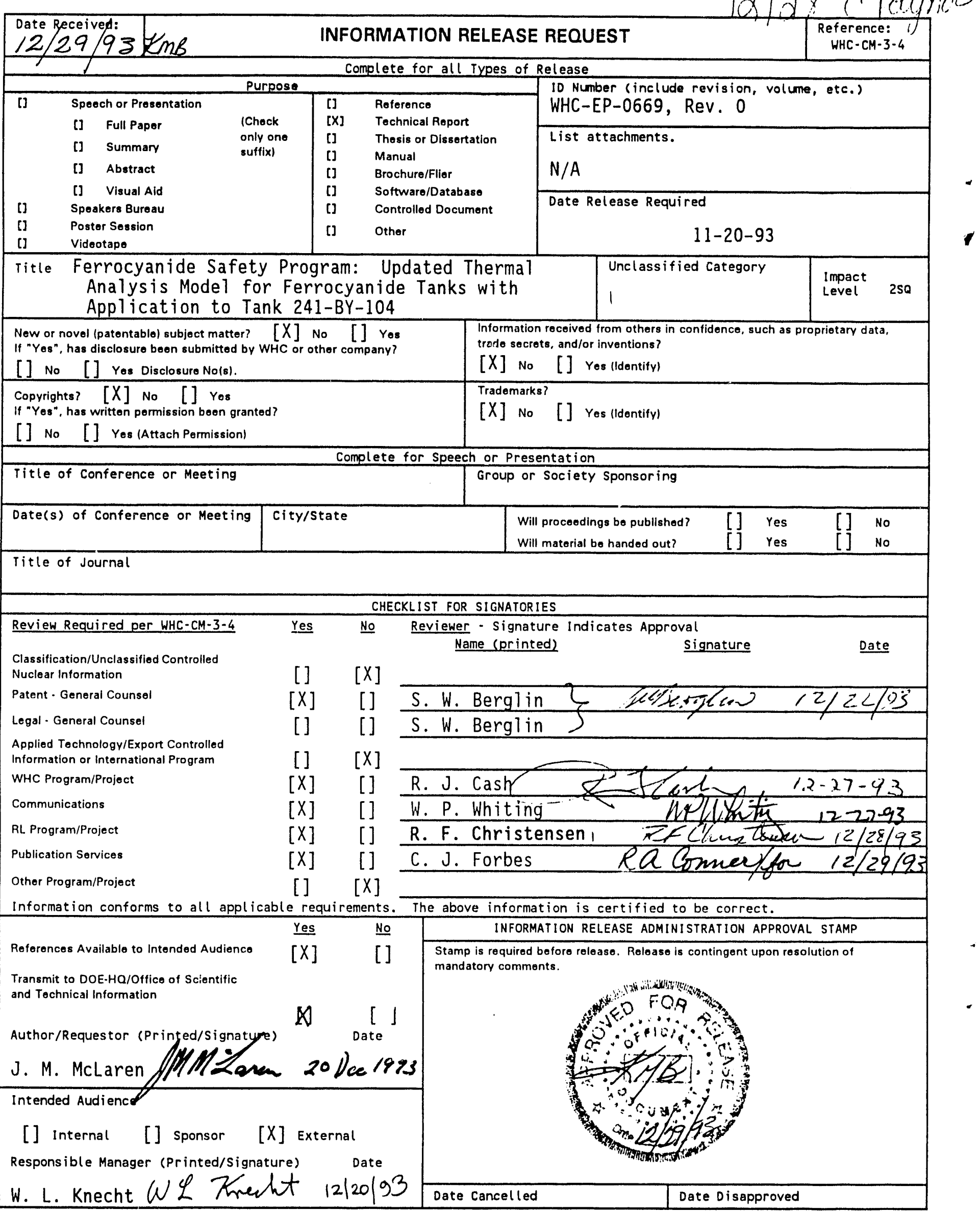


FERROCYANIDE SAFETY PROGRAM: UPDATED THERMAL ANALYSIS MODEL FOR FERROCYANIDE TANKS WITH APPLICATION TO TANK 241-BY-104

\author{
J. M. McLaren
}

\begin{abstract}
A computer model of a single-shell waste storage tank was created using the HEATING7 heat transfer code. The latest information available was used to determine the parameter values used for the model. Upper and lower bounds of the soil conductivity were developed and various methods of describing heat transfer paths were investigated with attention to their effect on the solution. The method used to estimate the heat loads and thermal properties of the waste within the single-shell waste storage tanks was improved to include past temperature and fill/transfer histories. The computer analysis was conducted under transient conditions, where previous analyses were conducted under steady-state conditions. The model was used to estimate the heat load of Tank 241-BY-104, located on the Hanford Site. The estimated heat load ranged from $1.465 \mathrm{~kW}$ to $3.224 \mathrm{~kW}$, with a median value of $2.345 \mathrm{~kW}$. In addition, a factor was determined that should be applied to the heat loads of tanks previously estimated using HEATING7 thermal analysis.
\end{abstract}




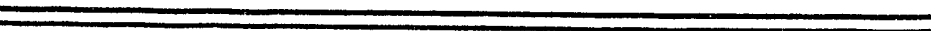

This page intentionally left blank. 


\section{CONTENTS}

1.0 INTRODUCTION $\ldots \ldots \ldots \ldots \ldots \ldots \ldots \ldots \ldots \ldots \ldots \ldots \ldots \ldots \ldots \ldots .1$

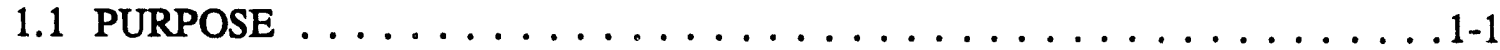

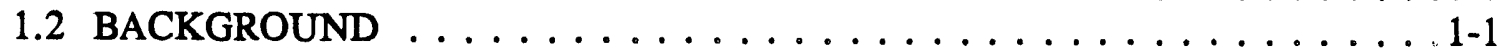

2.0 SUMMARY OF RESULTS $\ldots \ldots \ldots \ldots \ldots \ldots \ldots \ldots \ldots \ldots \ldots . . \ldots \ldots$

2.1 RESULTS OF MODEL DEVELOPMENT $\ldots \ldots \ldots \ldots \ldots \ldots \ldots \ldots$

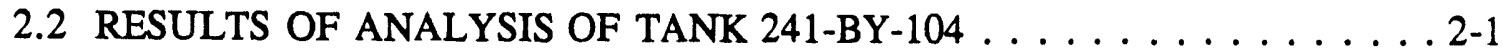

3.0 DESCRIPTION OF UPDATED MODEL $\ldots \ldots \ldots \ldots \ldots \ldots \ldots \ldots \ldots$

3.1 MODEL CONFIGURATION $\ldots \ldots \ldots \ldots \ldots \ldots \ldots \ldots \ldots \ldots \ldots$

3.2 HEAT TRANSFER MODELING $\ldots \ldots \ldots \ldots \ldots \ldots \ldots \ldots \ldots \ldots \ldots \ldots$

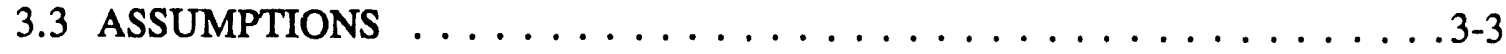

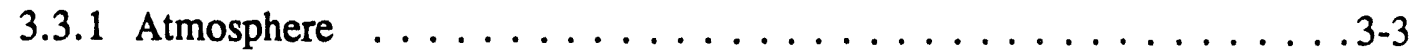

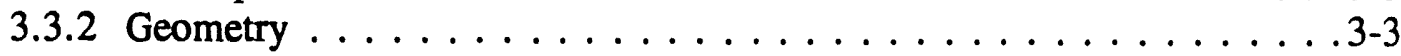

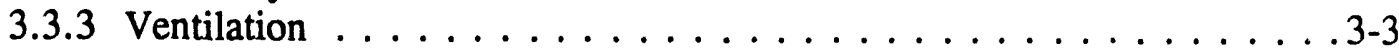

3.4 INPUT DATA AND UNCERTAINTIES $\ldots \ldots \ldots \ldots \ldots \ldots \ldots \ldots$

3.5 HEAT LOAD DETERMINATION METHOD . . . . . . . . . . . 3-4

4.0 DEVELOPMENT OF THE MODEL . . . . . . . . . . . . . . . 4-1

4.1 PARAMETERS AND CONDITIONS STUDIED $\ldots \ldots \ldots \ldots \ldots \ldots 4-1$

4.2 THERMAL CONDUCTIVITY OF SOIL $\ldots \ldots \ldots \ldots \ldots \ldots \ldots .4$

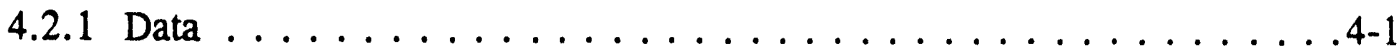

4.2.2 Soil Moisture Estimates $\ldots \ldots \ldots \ldots \ldots \ldots \ldots \ldots . \ldots \ldots$

4.2 .3 Results . . . . . . . . . . . . . . . . . .4-3

4.2.4 Supporting Studies $\ldots \ldots \ldots \ldots \ldots \ldots \ldots \ldots . \ldots \ldots$.4 $\ldots \ldots \ldots$

4.3 BOUNDARY CONDITIONS $\ldots \ldots \ldots \ldots \ldots \ldots \ldots \ldots \ldots$

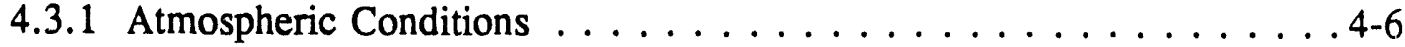

4.3.2 Water Table .......................4-6

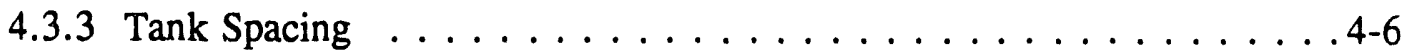

4.4 CONVECTIVE HEAT TRANSFER STUDIES $\ldots \ldots \ldots \ldots \ldots \ldots .4-7$

4.5 RADIATIVE HEAT TRANSFER STUDIES $\ldots \ldots \ldots \ldots \ldots \ldots \ldots .4-8$

4.6 TRANSIENT VERSUS STEADY-STATE STUDIES $\ldots \ldots \ldots \ldots \ldots \ldots$ 4-8

4.6 .1 Heat Loads . . . . . . . . . . . . . . . . . . . . . . 4-8

4.6.2 Forced Ventilation . . . . . . . . . . . . . . .4-8

4.7 INITIAL TEMPERATURE HISTORY $\ldots \ldots \ldots \ldots \ldots \ldots \ldots \ldots$. . . . . . .

5.0 ANALYSIS OF TANK $241-\mathrm{BY}-104 \ldots \ldots \ldots \ldots \ldots \ldots \ldots \ldots \ldots \ldots \ldots$. . . . . . . . . .

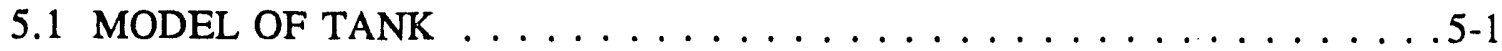

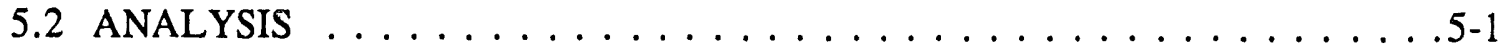

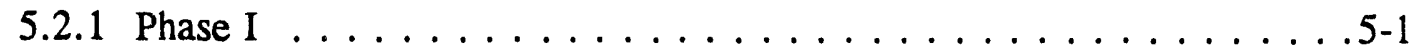

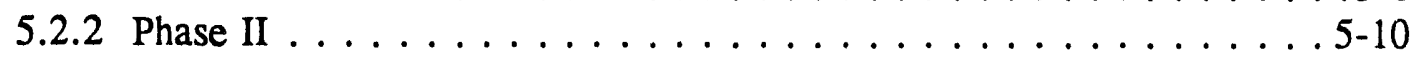




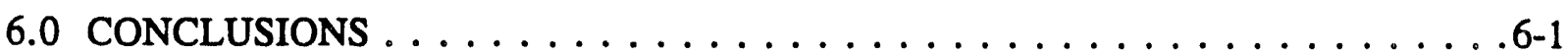

7.0 REFERENCES $\ldots \ldots \ldots \ldots \ldots \ldots \ldots \ldots \ldots \ldots \ldots \ldots \ldots \ldots \ldots \ldots \ldots \ldots .1$

APPENDIX A METEOROLOGICAL DATA $\ldots \ldots \ldots \ldots \ldots \ldots \ldots \ldots$ A-1

APPENDIX B THERMAL CONDUCTIVITY OF HANFORD WASTE TANK SOLIDS AND SX TANK FARM SOIL SAMPLES . . . . . . . . B-1 


\section{LIST OF FIGURES}

3-1. HEATING Model of Tank 241-BY-104 . . . . . . . . . . . . 3-2

4-1. Soil Conductivity versus Water Content $\ldots \ldots \ldots \ldots \ldots \ldots \ldots \ldots$ 4-2

4-2. Layout of Soil Surrounding Tank $241-B Y-104 \ldots \ldots \ldots \ldots \ldots \ldots \ldots$. . . . . . .

4-3. Change in Maximum Waste Temperature

with Increasing Depth of Dry Soil $\ldots \ldots \ldots \ldots \ldots \ldots \ldots \ldots \ldots . \ldots .5$

4-4. BY Tank Farm Layout $\ldots \ldots \ldots \ldots \ldots \ldots \ldots \ldots \ldots \ldots \ldots .4 \ldots \ldots \ldots$

4-5. Comparison of Base and Trial Case Temperature Histories . . . . . . . . . 4-10

4-6. Comparison of Base and Trial Case Final Results . . . . . . . . . . . . 4-10

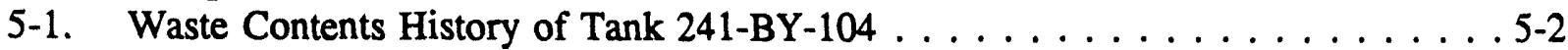

5-2. Temperature History of Tank 241-BY-104 . . . . . . . . . . . . 5-2

5-3. Vertical Temperature Data, Early $1982 \ldots \ldots \ldots \ldots \ldots \ldots \ldots \ldots$. . . . . . . . . .

5-4. Model of Tank 241-BY-104 with Waste . . . . . . . . . . . . . . . .5-5

5-5. Predicted Vertical Temperatures versus Data, $1982 \ldots \ldots \ldots \ldots \ldots \ldots \ldots$. . . 5-7

5-6. Temperature versus Time for Tank 241-BY-104 . . . . . . . . . . . . 5-8

5-7. Vertical Temperatures at Various Radii . . . . . . . . . . . . . . . . . . 5-9

5-8. Horizontal Temperatures at Various Depths . . . . . . . . . . . . . . . . . 5-9

5-9. Vertical Temperature Distribution for Upper and Lower Bound Cases . . . . . . . . . . . . . . . . . 5-10

5-10. Normalized Horizontal Sludge Temperature Distributions . . . . . . . . . 5-12

5-11. Comparison of Predicted versus Data Temperatures

Tank 241-BY-104 Upper Bound . . . . . . . . . . . . . . . . . . . . . . . 5-14

5-12. Comparison of Predicted versus Data Temperatures

Tank 241-BY-104 Lower Bound . . . . . . . . . . . . . . . . . . . . . . . . . . 5-15

\section{LIST OF TABLES}

1-1. Ferrocyanide Tank Heat Load Comparisons . . . . . . . . . . . . . . 1-2

4-1. SX Farm Soil Conductivities Under Varying Conditions . . . . . . . . . . 4-2

4-2. Soil Conductivities with Error Bounds $\ldots \ldots \ldots \ldots \ldots \ldots \ldots \ldots \ldots$ 4-3

5-1. Vertical Temperature Data for $1982 \ldots \ldots \ldots \ldots \ldots \ldots \ldots$. . . . . . . . .

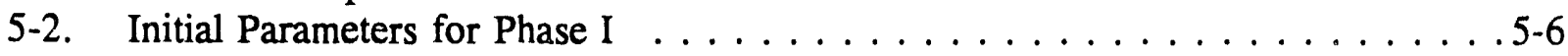

5-3. Parameter Values for Basic Fit $\ldots \ldots \ldots \ldots \ldots \ldots \ldots \ldots \ldots . . \ldots \ldots$

5-4. Temperature Data for Initial Conditions . . . . . . . . . . . . . 5-13

5-5. December 31, 1992 Temperature Data for 241-BY-104 . . . . . . . . . . 5-13

5-6. Results of Upper Bound, Lower Bound, and Median Values . . . . . . . 5-15 


\section{LIST OF ACRONYMS}

ITS In-Tank Solidification

SST Single-shell storage tanks

TC Thermal conductivity

WHC Westinghouse Hanford Company 


\subsection{INTRODUCTION}

\subsection{PURPOSE}

The purposes of this report are to document the updated thermal analysis model for ferrocyanide tanks and to use the model to determine the heat load of Tank 241-BY-104. This new model utilizes several new parameters and a new technique, which are described in this report. The new model is considered more accurate than the previous model, and all future thermal analyses of ferrocyanide tanks will use this updated model.

\subsection{BACKGROUND}

During the middle to late 1950 's, a program was begun to concentrate the radioactive waste products of the uranium and plutonium recovery processes. This program used sodium nickel ferrocyanide to precipitate radioactive cesium from the waste streams. The precipitate was then stored in large, underground single-shell tanks at the Hanford Site in south central Washington.

The precipitated solids also contain nitrates/nitrites. Ferrocyanide and nitrates/nitrites can be made to react violently under certain conditions. When thermally hot solutions were added to several of the tanks, the dissolved compounds in these solutions formed crystals as they cooled, and these crystals precipitated out on top of the previous solids.

Several of the tanks have been "stabilized," a process that included removing as much pumpable liquid as possible from the tanks. This liquid contained heat-producing radionuclides. Because of the many transfers involved, the lack of accurate inventory data for the various waste streams, and the absence of a need for an accurate value of the heat load, the heat loads of the ferrocyanide waste storage tanks have only been estimated. As a result of the intense radiation field within these tanks, the chemical content of the waste has changed. This, coupled with the fact that the characteristics of the input waste were not well known, has resulted in uncertainty in the thermal characteristics of the stored sludge. All of these parameters are needed to evaluate the safety of these tanks.

Previous methods for determining heat loads of single-shell ferrocyanide waste storage tanks (SSTs) included psychrometric analyses of the inlet and outlet ventilation air, computations of heat loads from estimations of the radionuclide inventory in the tanks, and thermal analysis using computer models. The results of these methods have yielded heat load values that do not correlate well with the reported tank inventories, as Table 1-1, derived from tank farm surveillance reports (Hanlon 1991), indicates. The tanks are grouped by volume of waste. Note how the maximum temperatures and the listed heat loads seem inconsistent. 
Table 1-1. Ferrocyanide Tank Heat Load Comparisons.

\begin{tabular}{|c|c|c|c|}
\hline Tank & $\begin{array}{c}\text { Sludge } \\
\text { level (in.) }\end{array}$ & $\begin{array}{c}\text { Max waste } \\
\text { temp ( }{ }^{\circ} \mathrm{F} \text { ) }\end{array}$ & $\begin{array}{c}\text { Listed heat } \\
\text { load (Btu/h) }\end{array}$ \\
\hline BY-106 & 241 & 131 & 12,200 \\
BY-105 & 190 & 122 & 37,700 \\
BY-111 & 174 & 86 & 34,200 \\
& & 129 & 17,000 \\
BY-104 & 155 & 82 & 8,600 \\
BY-103 & 153 & 122 & 25,200 \\
BY-110 & 152 & 76 & 8,200 \\
BY-101 & 148 & & \\
TX-118 & 134 & 77 & 4,900 \\
BY-112 & 113 & 82 & $<10,000$ \\
BY-107 & 104 & 98 & 10,000 \\
BX-111 & 91 & 67 & $<10,000$ \\
BY-108 & 90 & 11 & 23,000 \\
BX-110 & 80 & 63 & $<10,000$ \\
T-107 & 73 & 60 & $<10,000$ \\
TY-103 & 66 & 69 & $<10,000$ \\
I-101 & 56 & 69 & $<10,000$ \\
TY-101 & 50 & 64 & $<10,000$ \\
C-112 & 45 & 77 & $<10,000$ \\
BX-102 & 42 & 64 & $<10,000$ \\
C-108 & 31 & 70 & $<10,000$ \\
C-109 & 31 & 74 & 10,000 \\
C-111 & 28 & 68 & 10,000 \\
TY-104 & 24 & 63 & $<10,000$ \\
BX-106 & 24 & 63 & $<10,000$ \\
\hline
\end{tabular}

The method used in this report utilizes computer analysis of the tank and its contents, along with the temperature data obtained from thermocouple trees placed in the tanks, to determine the heat load of the tanks and the thermal conductivity of the waste. A computer model of the tank and its contents is used, and the surrounding soil is included. 
The new model described in this report will utilize improved data concerning several parameters that have been shown to be necessary. Among them are a detailed analysis of the conductivity of the soil surrounding the tank, transient behavior from the filling and temperature history of the tank, and the addition of forced ventilation to the model. This model is more accurate and versatile than previous modeling techniques, and will permit more accurate analysis of the thermal characteristics and heat loads of the waste in the SSTs. 
This page intentionally left blank. 


\subsection{SUMMARY OF RESULTS}

\subsection{RESULTS OF MODEL DEVELOPMENT}

An updated model and method for thermal analysis of ferrocyanide tanks were developed. The model is based on the HEATING7 code. Parameter studies were conducted to determine the effect of various heat transfer paths on the solution. Radiant and convective heat transfer to the side walls of the tank was found to be insignificant and could be omitted without reducing the accuracy of the solution. An evaluation was performed to determine the best values of thermal properties to be used, including the thermal conductivity of the soil as a function of anticipated soil moisture content. Upper and lower bound values were determined and used in the model. Transient effects were found to be significant, and as a result, the model uses a transient solution method to model the effect of the fill, temperature, and ventilation history of the tanks from 1957 to the present.

\subsection{RESULTS OF ANALYSIS OF TANK 241-BY-104}

An analysis of Tank 241-BY-104 was conducted using the new model to determine the upper and lower bounds of the tank's heat load. The analysis determined that the upper bound heat load was $3.22 \mathrm{~kW}(11,000 \mathrm{Btu} / \mathrm{h})$ and the lower bound was $1.47 \mathrm{~kW}(5,000$ $\mathrm{Btu} / \mathrm{h})$. The average is $2.34 \mathrm{~kW}(8,000 \mathrm{Btu} / \mathrm{h})$. Previously reported values of the heat load were between $1.465 \mathrm{~kW}(5,000 \mathrm{Btu} / \mathrm{h})$ and $1.61 \mathrm{~kW}(5,500 \mathrm{Btu} / \mathrm{h})$, which are close to the lower bound determined by this analysis and within the error band. As a result of this analysis, the value of the heat loads determined by previous thermal analyses in McLaren 1993 have been multiplied by a factor of 1.6 to more accurately predict their average value. 
This page intentionally left blank. 


\subsection{DESCRIPTION OF UPDATED MODEL}

\subsection{MODEL CONFIGURATION}

The model was developed from the model created for analysis of the heat load of Tank 241-BY-104. The model was created for use with the HEATING7 code, with regions describing the tank, the contents of the tank, and the surrounding soil. The tank was modeled using data from the tank drawings, with a flat floor, cylindrical sides, and stepped roof. Provision was made to use a stepped floor in the model should it be necessary to model the dished floor of the tank. The concrete dome of the tank was not modeled because it adds complexity. The volume of the dome was included in the soil cover over the tank. The thermal conductivity of the soil is close to that of the concrete, as are the density and heat capacity; therefore, little inaccuracy is introduced by using this method. Because of symmetry, the tank was modeled in cylindrical coordinates, in two dimensions only, vertically from the soil surface to the water table, and radially from the centerline to the outer boundary of the model. Figure 3-1 shows the Tank 214-BY-104 model as developed for the HEATING7 code.

The model uses 3 regions inside the tank to describe the waste, 7 regions inside the tank to describe the airspace, and 16 regions outside the tank to describe the soil surrounding the tank. The 3 regions inside the tank describing the waste are in the form of layers. The characteristics of these 3 regions will change during the analysis of the tank because the waste volume within the tank changes over time, such as when the tank was saltwell pumped between 1982 and 1983. The material description of these regions was changed by creating a new model after stabilization.

The physical boundaries of the model are: (1) the soil surface with a forced convection heat transfer coefficient for heat rejecting to a constant temperature of $12.2{ }^{\circ} \mathrm{C}\left(54{ }^{\circ} \mathrm{F}\right) ;(2)$ a

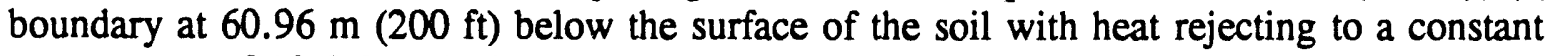
temperature of $12.8^{\circ} \mathrm{C}\left(55^{\circ} \mathrm{F}\right) ;(3)$ the centerline of the tank, projected up to the surface and down to the 60.96-m boundary; and (4) a reflective boundary at $17.54 \mathrm{~m}(57.55 \mathrm{ft})$ horizontally. 
Figure 3-1. HEATING Model of Tank 241-BY-104.

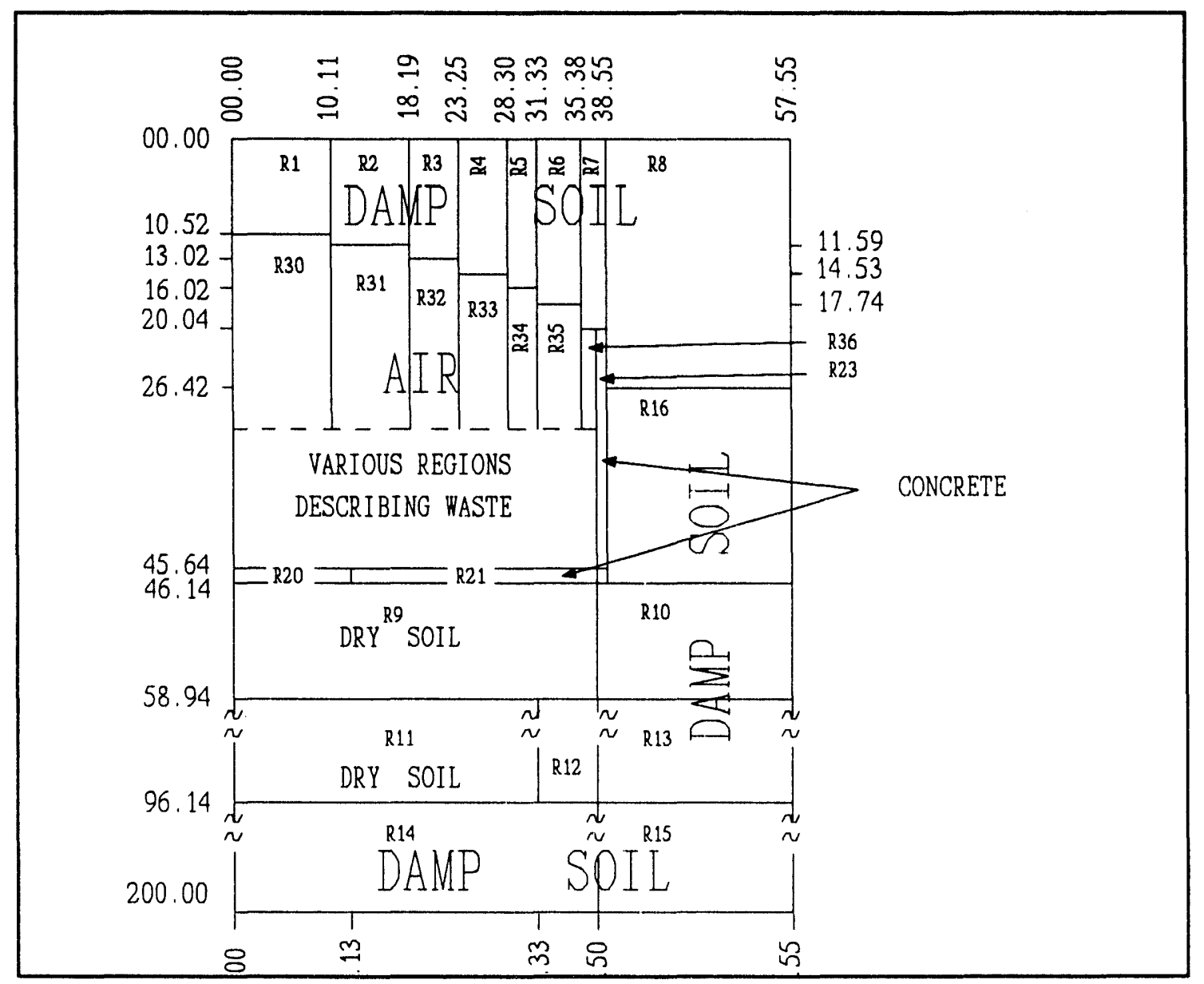

\subsection{HEAT TRANSFER MODELING}

Heat transfer within the waste itself is by conduction. While there was convection within the liquid regions of the waste, this method of heat transfer was accounted for by using a high thermal conductivity within those regions. Heat transfer within the gas space in the tank is by radiation and convection. Convective heat transfer and radiative heat transfer are from the waste surface to the domed top of the tank. During the period from the time the tank was placed into In-Tank Solidification (ITS) service to the time of saltwell pumping, the tank was on forced ventilation. This is accounted for by a prescribed heat loss from the top surface of the tank contents. Breathing of the tank from atmospheric pressure changes is not taken into account because studies of the volume exchange due to this mechanism ( 3 to 9 tank volumes per year) indicated that the heat loss was too low to be noticed. Heat transfer from the tank to the soil boundaries was by conduction through the soil surrounding the tank. 


\subsection{ASSUMPTIONS}

\subsubsection{Atmosphere}

The atmospheric air temperature was assumed to be constant over the entire time period studied. An average of temperatures over 60-plus years was used in the model. Meteorological data is included as Appendix A.

\subsubsection{Geometry}

The amount of soil surrounding each tank varies depending upon the position of the tank in the farm. Surrounding soil is considered to be in the shape of a square for the tanks wholly within the farm, and in the shape of a rectangle with the tank offset for those tanks on the edges of the farm. The actual geometry was simplified by assuming that the soil around each tank is in the shape of a cylinder and equal in volume to the amount surrounding a tank that is completely enclosed within the farm.

\subsubsection{Ventilation}

The heat loss from forced ventilation was assumed to be constant during the period that forced ventilation was applied. While this is not correct, the temperatures of the waste during this period (1970 to 1982) were quite high, and the resulting error is considered to be small. Also, the purpose of the analysis for this period was to develop soil temperatures around the tank, not accurate temperatures within the tank, and thus highly accurate waste temperatures were not necessary. The modeled ventilation heat loss was from the upper surface of the tank contents.

\subsection{INPUT DATA AND UNCERTAINTIES}

The data used as input for determining the heat load and thermal characteristics of the waste in the SSTs are the temperature readings at various levels within the waste and/or within the airspace of the tank. Discussions with C. C. Scaief of Westinghouse Hanford Company (WHC) indicate that these readings may have an error of as much as $\pm 5^{\circ} \mathrm{C}$ $\left( \pm 9^{\circ} \mathrm{F}\right)$ under the worst conditions, but that usually the error is only $\pm 1.7^{\circ} \mathrm{C}\left( \pm 3^{\circ} \mathrm{F}\right)$. This error arises primarily from temperature measurement errors at the reference junction, and as a result, temperature errors for a given thermocouple string are almost always in one direction, either plus or minus, but not both. This means that the shape of the data curves is accurate and that the thermal conductivity errors are not caused by extreme variations in the slope of the temperature-versus-height curve. 
Other data needed for the computations are the thermal conductivities of the surrounding soil and the waste itself. The thermal conductivity of the waste is a value predicted by the solution for heat load. The value used for the soil is computed from laboratory data (see Appendix B) and from moisture estimations provided by Dr. M. G. Piepho of WHC from analyses of grout vault studies (Kincaid et al., 1993). The accuracy of these data is considered to be $\pm 20 \%$.

Other data used for the analysis are the fill/transfer and temperature histories of the tank. The fill/transfer history is generally known, but the temperature history is known only from about 1975 on. As a result of this gap in temperature history, there can be considerable error between the actual and the calculated heat load at various times between 1957 and 1983. The intent in developing this history, however, was to heat the soil surrounding the tank to the correct temperature at the time of stabilization; therefore, this error does not have much effect on the solutions at the end of the period studied (1984 to 1993). Parametric analyses have shown that sizeable errors can exist between the computed and actual temperatures within the tank with very little change $\left(<0.5^{\circ} \mathrm{C},<1{ }^{\circ} \mathrm{F}\right)$ in the soil temperatures. This insensitivity allows good analyses using estimated data.

\subsection{HEAT LOAD DETERMNUATION METHOD}

An iterative process is used to determine the heat loads of the tanks. The analysis is conducted in two phases. The first phase models the tank from the time of initial filling to the time it was saltwell pumped. The second phase models the tank from the time of saltwell pumping to the present. The purpose of Phase I is to preheat the soil to the proper temperatures and temperature distribution just prior to saltwell pumping. Phase II starts at this point with the current tank configuration and develops the present heat load of the tank. Two phases are required because the HEATING'7 code does not allow changes in the region dimensions during a given computer run, even with restarts.

In Phase I, a model of the tank prior to stabilization is created. The input data are the vertical temperature profile measurements taken at specific locations in the tank, the fill/transfer history of the tank, and the tank temperatures. The process starts by developing the fill/transfer history data into a plot to determine the average contents and region heights. The salient points of the temperature history are identified. In the case of Tank 241-BY-104, the salient points are the low temperature of $37.8^{\circ} \mathrm{C}\left(100^{\circ} \mathrm{F}\right)$ in June 1970 , the high temperature of $98.9^{\circ} \mathrm{C}\left(210^{\circ} \mathrm{F}\right)$ in July 1970 , the temperature in June 1974 , the final temperature before saltwell pumping of $71.1^{\circ} \mathrm{C}\left(160^{\circ} \mathrm{F}\right)$, and the shape of the temperature decay between 1976 and 1982 . When this process has been completed, a heat load-versustime curve is developed. These temperature histories will require that the heat load-versustime curve be stepped at various times. This curve is input into the model and a transient problem is computed and analyzed. The intent is to match the temperatures at the salient points previously determined. Accomplishing the match will require altering the thermal conductivity of the waste, the initial heat load of the tank, the heat load versus-time-curve, 
and the ventilation load. When a fairly accurate preheat of the soil surrounding the tank (at the time just before saltwell pumping) has been accomplished, the second phase of the analysis begins.

Phase II begins by altering the model to describe the contents of the tank after the bulk of the free liquid has been removed. A soil temperature map at the time of saltwell pumping is determined from Phase I, and this map is input into the model as a series of normalized temperature-versus-position curves. The temperature-versus-height data of the waste at the beginning of this second phase is input as an initial condition and the iterative process begins again, this time from the time of saltwell pumping to the present. Once again, the conductivity of the waste is altered as well as the heat load distribution and the initial heat load. The initial heat load is taken at the time just after saltwell pumping rather than at the starting point of Phase I. A close match between the predicted temperatures and the data is necessary at the end of the problem in order to develop as good a prediction of heat load and waste thermal conductivity as possible. 
This page intentionally left blank. 


\subsection{DEVELOPMENT OF THE MODEL}

\subsection{PARAMETERS AND CONDITIONS STUDIED}

The method used to determine the heat load of the tanks and the thermal conductivity of the waste uses computer analysis of the tank, its contents, and the surrounding soil along with temperature data obtained from thermocouple trees placed in the tank. The computer analysis uses a model with boundary conditions to describe the limits of the system, such as the atmosphere above the soil and the water table below the surface, and assumed values for thermal conductivity of the surrounding soil. The analysis method using this model requires assumptions for the conductivity of tank contents to predict the heat load of the tank. In order to make a more accurate estimation of the heat load by this method, the model has been refined with improved assumptions and more accurate values of the various parameters. The following parameters were evaluated and their results incorporated into this new model.

1. The conductivity of the soil surrounding the tank.

2. The boundary conditions of the water table depth and temperature and the atmospheric conditions.

3. The effect of convective heat transfer from the surface of the waste to the side walls of the tank. Convective heat transfer from the waste to the tank dome was already included in the model.

4. The effect of radiative heat transfer from the surface of the waste to all visible structures within the tank. Previously, the only radiative heat transfer considered was from the waste surface to the dome.

5. The effect of using a transient solution, from the initial fill of the tank with ferrocyanide waste to the present. Previous solutions used steady-state conditions.

6. The effect of the accuracy of the initial filling data on the final transient solution.

\subsection{THERMAL CONDUCTIVITY OF SOIL}

\subsubsection{Data}

The data used for the soil thermal conductivity estimates come from D. G. Bouse (see Appendix B). Bouse determined the conductivity of various kinds of soils found in the SX tank farm by making measurements of these soils under different conditions. Unfortunately, 
there was no mention of composition breakdown in the report, so averages cannot be weighted by composition. These results are summarized in Table 4-1.

Table 4-1. SX Farm Soil Conductivities Under Varying Conditions All Values are in $\mathbf{W} / \mathbf{m}-{ }^{\circ} \mathbf{C}$.

\begin{tabular}{|c|c|c|c|c|c|}
\hline Soil type & $\begin{array}{l}\text { Dry, loosely } \\
\text { poured }\end{array}$ & $\begin{array}{c}\text { Dry, } \\
\text { vibrated }\end{array}$ & 3\% Water & $6 \%$ Water & $12 \%$ Water \\
\hline Muddy sand & & & .262 & .591 & .785 \\
\hline Sand & .279 & .358 & .220 & .708 & .979 \\
\hline $\begin{array}{l}\text { Slightly } \\
\text { muddy, } \\
\text { gravely sand }\end{array}$ & .388 & .682 & .308 & .757 & .757 \\
\hline $\begin{array}{l}\text { Average of } \\
\text { these results }\end{array}$ & .334 & .520 & .263 & .685 & .840 \\
\hline $\begin{array}{l}\text { Average of all } \\
\text { results }\end{array}$ & .347 & .474 & .263 & .685 & .840 \\
\hline
\end{tabular}

A plot of the average soil conductivity versus water content is shown as Figure 4-1.

As can be seen, the value of the conductivity at $3 \%$ water appears to be in error. The laboratory results depicted in Table 4-1 indicate that the conductivity is less than the dry, loosely poured soils. Consequently, the straight line from 0 to $6 \%$ moisture will be used for estimation purposes.

\subsubsection{Soil Moisture Estimates}

Studies in support of the grout vault project have developed estimates of the water content of the soils surrounding the grout vaults (Kincaid, et al., 1993). These studies indicate that the soil moisture content is relatively constant with depth, but that the vault provides an "umbrella" over the soil under it, reducing the amount of moisture in the soil under the vault. Additionally, the heat generated in the vault dries the soil directly under the vault. All of these factors should be considered in evaluating the soil around the SSTs. A factor to consider is that the moisture will not just move straight down from around the tank, but will migrate into the soil under the tank, with more penetration as the depth increases. One of the authors of the Kincaid report, Dr. M. G. Piepho, indicated that the probable maximum water content of the soil is $10 \%$ by weight over and around the tank, and $2.5 \%$ by weight under the tank. Borehole studies in the $\mathrm{C}$-farm indicate that the average water content of the soil is $4 \%$ (Caggiano and Goodwin 1991). These studies also indicate that the soil grain sizes across the farm are highly variable (Price and Fecht 1976). Consequently, there may be a wide range of conductivities through tank farm soils. 
Figure 4-1. Soil Conductivity versus Water Content.

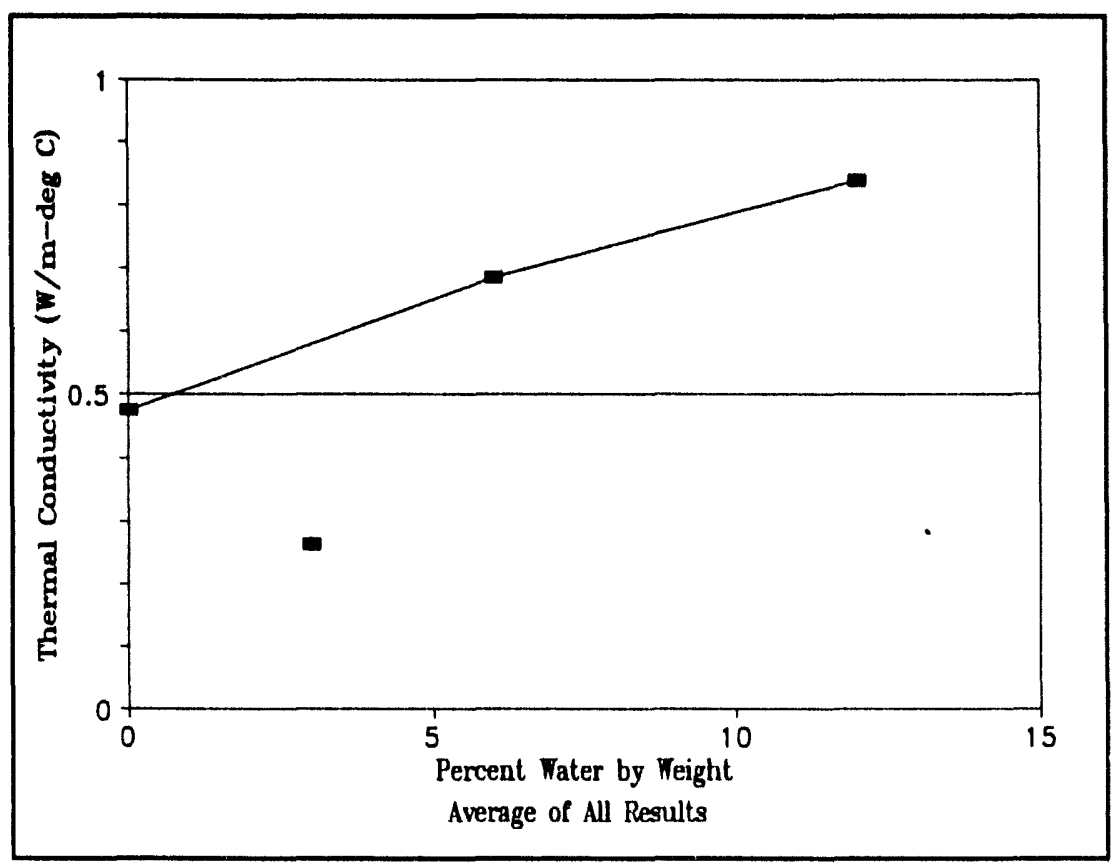

\subsubsection{Results}

The above estimates of soil water content are expected to be accurate within $20 \%$. The data determined by Bouse had no accuracy limits, but are also assumed to be within $20 \%$. Using these values, the upper and lower limits of the soil conductivities to be used by the model are calculated to be as shown in Table 4-2.

Table 4-2. Soil Conductivities with Error Bounds.

\begin{tabular}{|l|c|l|c|c|}
\hline & Moisture & \multicolumn{1}{|c|}{ Error } & Conductivity & $20 \%$ Error \\
\hline Upper bound & $10 \%$ & $\begin{array}{l}+20 \% \rightarrow \\
12 \%\end{array}$ & $.840 \mathrm{~W} / \mathrm{M}-{ }^{\circ} \mathrm{C}$ & $1.008 \mathrm{~W} / \mathrm{m}-{ }^{\circ} \mathrm{C}$ \\
\hline Lower bound & $10 \%$ & $-20 \% \rightarrow 8 \%$ & $.737 \mathrm{~W} / \mathrm{m}-{ }^{\circ} \mathrm{C}$ & $.589 \mathrm{~W} / \mathrm{m}-{ }^{\circ} \mathrm{C}$ \\
\hline Upper bound & $2.5 \%$ & $\begin{array}{l}+20 \% \rightarrow \\
3 \%\end{array}$ & $.580 \mathrm{~W} / \mathrm{m}-{ }^{\circ} \mathrm{C}$ & $.696 \mathrm{~W} / \mathrm{m}-{ }^{\circ} \mathrm{C}$ \\
\hline Lower bound & $2.5 \%$ & $-20 \% \rightarrow 2 \%$ & $.544 \mathrm{~W} / \mathrm{m}-{ }^{\circ} \mathrm{C}$ & $.435 \mathrm{~W} / \mathrm{m}-{ }^{\circ} \mathrm{C}$ \\
\hline
\end{tabular}


These values are incorporated into the model as shown on Figure 4-2.

Figure 4-2. Layout of Soil Surrounding

Tank 241-BY-104.

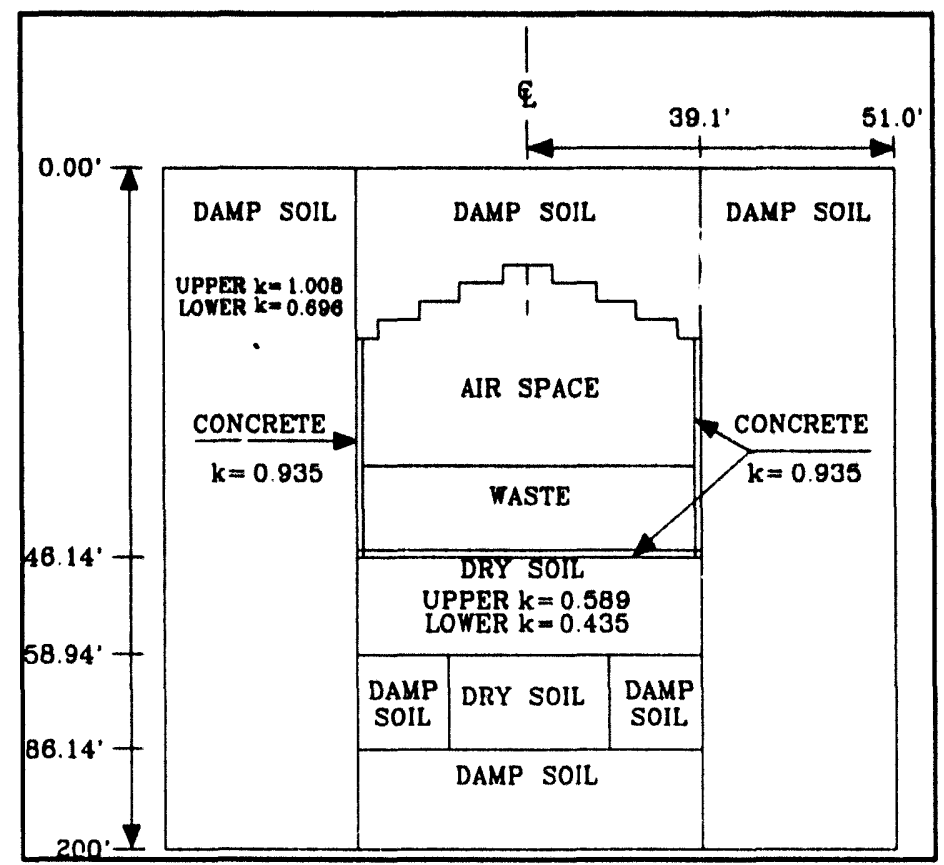

\subsubsection{Supporting Studies}

In order to study encroachment effects of water into dry soil under a tank, a model of Tank 241-BY-104 was constructed for the HEATING7 code which divides the soil under the tank into regions with lower boundaries of $3.90 \mathrm{~m}(12.8 \mathrm{ft}), 8.29 \mathrm{~m}(27.20 \mathrm{ft}), 12.19 \mathrm{~m}$ $(40 \mathrm{ft})$, and $22.19 \mathrm{~m}(72.8 \mathrm{ft})$ below the tank. The diameters of these regions were made to approximate an inverted cone from the bottom edge of the tank with its apex at the centerline of the tank at the depth of the water table $(60.96 \mathrm{~m}[200 \mathrm{ft}])$.

The study started with the conductivity of all the soil surrounding the tank were considered to be that of soil with a moisture content of $10 \%$, described as "damp." The conductivity of the soil under the tank was then changed to be that of soil with a moisture content of $2.5 \%$, described as "dry." This was done in stages, starting with the soil in the region directly under the tank and ending with the shape approximating an inverted cone under the tank. A computer run was made with all the soil under the tank from the centerline to the diameter of the tank wall considered to be dry, in order to compare the results. The results of this parametric study are shown in Figure 4-3. 
Figure 4-3. Change in Maximum Waste Temperature with Increasing Depth of Dry Soil.

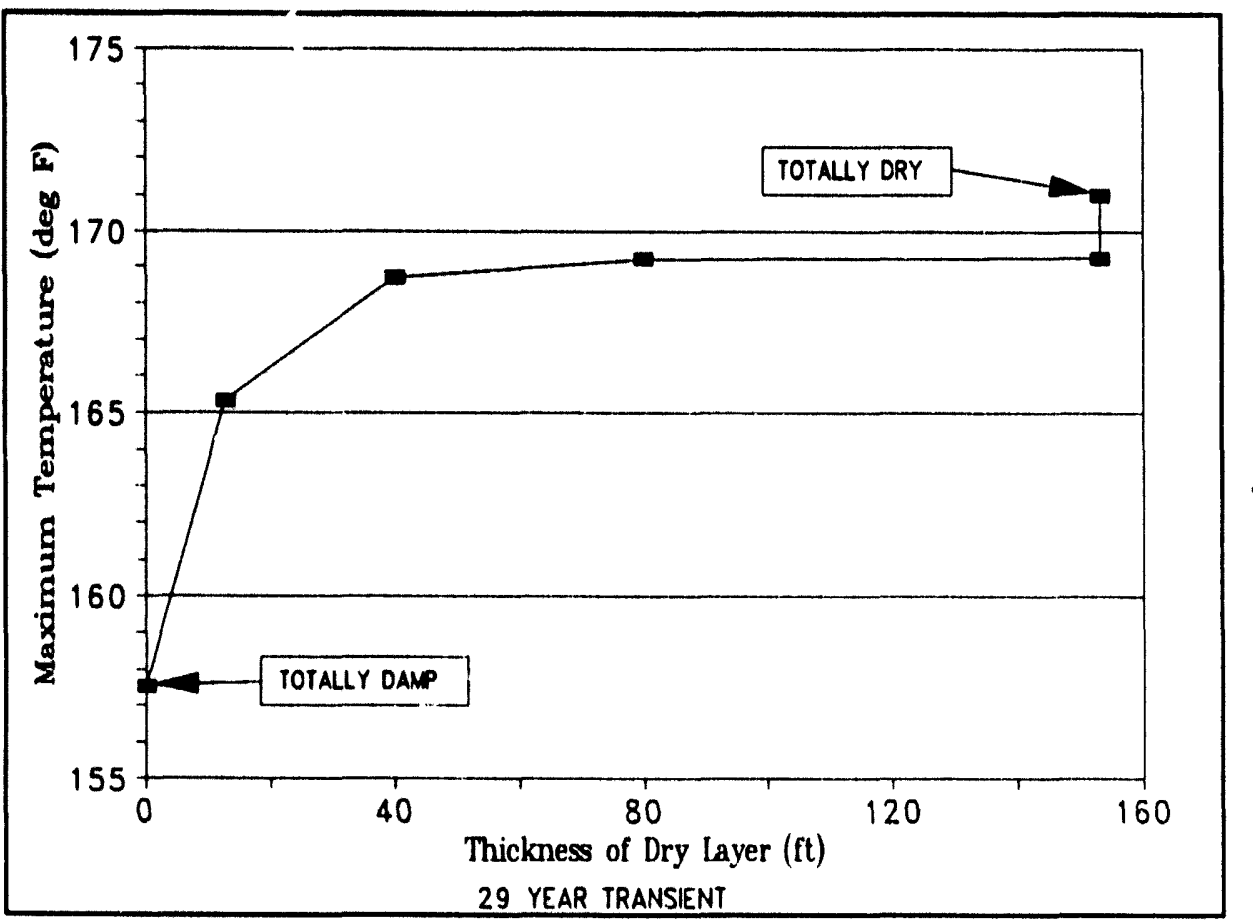

The point labeled "totally damp" is the result of the run with all the soil surrounding the tank at $10 \%$ moisture. The point labeled "totally dry" is the result of the run with ail the soil down to the water table and with a diameter equal to that of the tank at $2.5 \%$ moisture. The point directly beneath it is the result of the run with the soil under the tank in the shape of an inverted cone at $2.5 \%$ moisture, as explained above. These results indicate that changes in the conductivity of the soil at depths greater than $40 \mathrm{ft}$ below the tank have little effect on the temperature profile in the tank and can be ignored. This is of importance because the moisture content profile of the soil under the tank is not well known. Being able to ignore changes at depths greater than $40 \mathrm{ft}$ below the tank means that it is unnecessary to determine this profile.

\subsection{BOUNDARY CONDITIONS}

The waste tanks must reject heat to the environment. The boundaries of this heat rejection have been considered to be the atmosphere above the soil cover over the tank, and the water table below the tank. The vertical surface between tanks in the tank farm is considered an adiabatic boundary condition. The effect of the neighboring tanks is to inhibit or prevent any further heat flow in that direction, depending upon their temperatures. In order to more accurately predict the temperature profiles within the waste storage tanks, these boundary conditions must be accurately known. 


\subsubsection{Atmospheric Conditions}

The atmospheric conditions at the Hanford Site have been studied since construction of the tank farms. The difficulty with using the weather data is that while average values for temperature, wind speed, humidity, etc. can be calculated, these values are rarely seen in actuality. The climate at the Hanford Site varies from extreme to extreme, with wide swings in conditions over relatively short time periods. An examination of weather data (Appendix A) will bear this out. Consequently, while average values for the parameters of interest may be calculated, the conditions they describe are of short duration and exist only in passing. This can present a problem for analyses that utilize transients with a time span of only a few years. For transients with a time span of many years, the use of averages is permissible because this time period represents statistical evaluation of a large data base. Since the transient studies to be investigated cover a time span of over 30 years, the use of average data is valid.

The average value for the dry bulb temperature from 1912 to 1975 is $12.2^{\circ} \mathrm{C}\left(54^{\circ} \mathrm{F}\right)$, and the average value for the wet bulb temperature from 1950 to 1970 is $6.7^{\circ} \mathrm{C}\left(44^{\circ} \mathrm{F}\right)$. The average value for the wind velocity from 1945 to 1970 is $12.9 \mathrm{kph}(8 \mathrm{mph})$. With this wind value, a heat transfer coefficient of $11.56 \mathrm{~W} / \mathrm{m}^{2}-{ }^{\circ} \mathrm{C}\left(2 \mathrm{Btu} / \mathrm{h}-\mathrm{ft}^{2}-{ }^{\circ} \mathrm{F}\right)$ was calculated. Boundary values calculated for the surface of the soil over the tank are a heat transfer coefficient of $11.56 \mathrm{~W} / \mathrm{m}-{ }^{\circ} \mathrm{C}$ rejecting to a temperature of $12.2{ }^{\circ} \mathrm{C}$.

\subsubsection{Water Table}

The depth of the water table at the Hanford Site tank farms has been considered to be

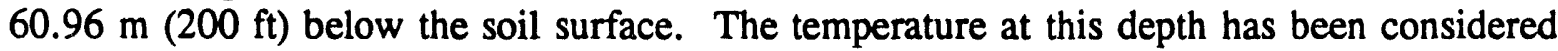
to be $12.8^{\circ} \mathrm{C}\left(55^{\circ} \mathrm{F}\right)$. These values were used to describe the lower boundary of the model.

\subsubsection{Tank Spacing}

A typical tank farm has 12 tanks arranged in 3 rows and 4 columns. The tanks are set at differing depths, such that at one end of a column of three the depth of the top of the tank will be $7 \mathrm{ft}$ below the surface, and at the other end the depth will be $9 \mathrm{ft}$ below the surface, with the center tank at $8 \mathrm{ft}$. The layout of the BY tank farm is shown in Figure 4-4. Drawings indicate that the surface of the soil over the tanks was intended to be graded such that the soil cover over each tank was constant. However, the elevations of the risers from the buried tanks are known and are all within a few inches of each other. As a result, it is easy to determine that the grade is quite level within the tank farm, as the risers all protrude nearly the same height above the ground. A discussion with Mr. A. T. Alstad of WHC Waste Tank Operations has verified this data. 
Figure 4-4. BY Tank Farm Layout.

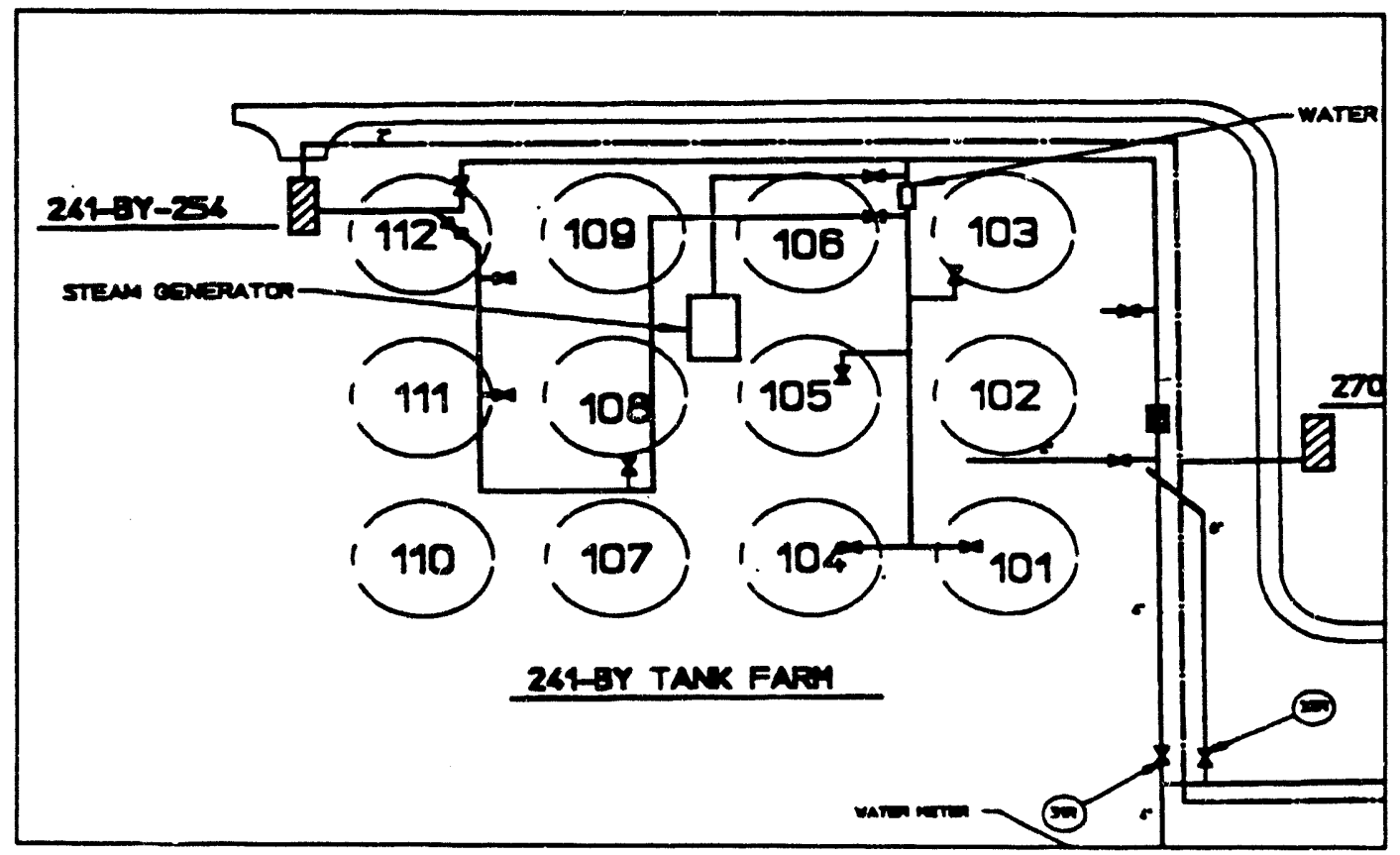

The spacing between tanks in tine BY tank farm, center to center, is $31.09 \mathrm{~m}$ (102 ft). The cylindrical coordinate system outer radius for the reflective boundary is $17.54 \mathrm{~m}$ $(57.55 \mathrm{ft}$ ), to account for all the area encompassed by the soil around the tank, a square $15.54 \mathrm{~m}(51 \mathrm{ft})$ on a side. Changes in the outer radius will cause changes in the temperature profile of the waste in the tank, but these changes are minimal within the limits of the tank spacing. There could be a perturbation in the waste temperature profiles of tanks on the outer rows of the tank farm, such as Tank 241-BY-104. These outer tanks will not have symmetrical heat rejection boundaries, and that part of the tank next to the more distant boundary will be cooler than the rest of the tank. Three-dimensional techniques may be required for thermal analysis should the thermocouple tree providing the temperature data be located on a side away from the tank farm. For those tanks along the outer rows that have the temperature measurements taken in the areas of the tanks that face into the tank farm, (including Tank 241-BY-104), and those tanks completely enclosed within the farm, the use of a radius of $17.54 \mathrm{~m}(57.55 \mathrm{ft})$ will be accurate.

\subsection{CONVECTIVE HEAT TRANSFER STUDIES}

Normally, convective heat transfer as calculated by the HEATING7 code transfers heat from one surface node to the surface node directly across from it, and does not involve the convecting medium. The code allows the use of surface nodes other than those directly across from each other, but the connections must be individually input. The results of a 
convection model that transferred heat from a surface node only to the surface node directly across from it were compared to the results of a convection model that transferred heat to all visible surface nodes. The resulting temperature differences were less than $0.28^{\circ} \mathrm{C}\left(0.5^{\circ} \mathrm{F}\right)$ in the waste and the surrounding soil. This means that a simplified convection model can be used without significant loss of accuracy.

\subsection{RADIATIVE HEAT TRANSFER STUDIES}

The results of a radiation model that views all available structures were compared against the results of a model in which the radiant heat was transferred from one surface node only to the node directly across from it. The resulting differences in maximum temperature of the waste were less than $0.28^{\circ} \mathrm{C}\left(0.5^{\circ} \mathrm{F}\right)$, with smaller differences as the distance from the point of maximum temperature increased. This allows a simplified radiation model to be used without significant penalty.

\subsection{TRANSIENT VERSUS STEADY-STATE STUDIES}

\subsubsection{Heat Loads}

Previous analyses have assumed that since the tanks were initially filled over 30 years ago, they have reached a quasi-steady-state condition. Studies were conducted on Tank 241-BY-104 to compare the effect of using a transient to predict the waste temperatures with the effect of using a steady-state solution for the same temperatures. These transients started at the time the tank was initially filled with ferrocyanide wastes (1957) and included the removal of free liquid during saltwell pumping in 1982-1983.

Thie initial conditions of the transient consisted of isothermal tank contents at $71.1^{\circ} \mathrm{C}$ $\left(160{ }^{\circ} \mathrm{F}\right)$, with the tank and surrounding soil at temperatures ranging from $12.2^{\circ} \mathrm{C}\left(54^{\circ} \mathrm{F}\right)$ at the surface to $12.8^{\circ} \mathrm{C}\left(55^{\circ} \mathrm{F}\right)$ at the depth of $60.95 \mathrm{~m}(200 \mathrm{ft})$ below the surface. The transient analysis attempted to match the temperature data with data taken at a time just prior to saltwell pumping, as well as with temperature data from 1993. The results of these studies showed that there was a difference between the predicted temperature values for the transient case and for the steady-state case when the same final heat load was used. This difference amounted to as much as $2.8^{\circ} \mathrm{C}\left(5^{\circ} \mathrm{F}\right)$ or more, with the transient temperatures being the hotter. This means that analyses based on a steady-state solution will predict heat loads that could be as much as $0.6 \mathrm{~kW}(2,050 \mathrm{Btu} / \mathrm{h})$ higher than a transient analysis using the same conditions. 


\subsubsection{Forced Ventilation}

During the period the tanks were in ITS service, and for some time afterward, the tanks were cooled by forced ventilation. During ITS service thernally hot liquids were added to the tanks and allowed to cool. To model this effect requires a knowledge of the heat removal rate resulting from the forced ventilation. This heat removal results from two components, the sensible heat of the ventilation air, and the evaporative heat from the supernate. This technique also requires a knowledge of the initial heat load of the tank, a parameter that must be developed from assumptions of the heat load removed during stabilization and the heat load that is in the tanks at the present. A parametric study was conducted to determine the effect of inaccuracies in the assumed ventilation heat loss.

The study was conducted by adding $1.465 \mathrm{~kW}(5,000 \mathrm{Btu} / \mathrm{h})$ of extra heat to the tank contents, both waste and supernate, and removing an equal amount of heat by ventilation heat loss. This case was run from 1957 to 1983 , at which point the supernate heat load, the extra heat load, and the ventilation heat loss were removed from the model. The problem was then continued from mid-1983 to 1993. The study showed that at the time the extra heat load was removed from the model (1983), the waste temperatures increased slightly with increasing heat loads, but that the surrounding soil was hardly perturbed at all. Increasing the added heat load from $1.465 \mathrm{~kW}(5,000 \mathrm{Btu} / \mathrm{h})$ to $2.931 \mathrm{~kW}(10,000 \mathrm{Btu} / \mathrm{h})$ caused an increase in the maximum waste temperature of $1.1^{\circ} \mathrm{C}\left(2^{\circ} \mathrm{F}\right)$ in 1983 . At the end of the transient (1993) there is no difference in maximum waste temperature. These results show that the inaccuracies introduced into the transient model by incomplete knowledge of the ventilation heat loss are negligible. However, an approximate knowledge of the initial heat load of the tank is necessary.

\subsection{INITIAL TEMPERATURE HISTORY}

A second analysis of the upper bound heat load was conducted using a different temperature history of the tank. In the base case, the temperature starts at $48.9^{\circ} \mathrm{C}\left(120^{\circ} \mathrm{F}\right)$, with salient points of $37.8^{\circ} \mathrm{C}\left(100^{\circ} \mathrm{F}\right)$ in June $1970,98.9^{\circ} \mathrm{C}\left(210^{\circ} \mathrm{F}\right)$ in July 1970 , $98.9^{\circ} \mathrm{C}$ in June 1974 , and $71.1^{\circ} \mathrm{C}\left(160^{\circ} \mathrm{F}\right)$ in 1982 . In the trial analysis, the initial temperature started at $37.8^{\circ} \mathrm{C}$, and the salient points to match were $37.8^{\circ} \mathrm{C}$ in June 1975 , $87.8^{\circ} \mathrm{C}\left(190^{\circ} \mathrm{F}\right)$ in 1977 , and $71.1^{\circ} \mathrm{C}$ in 1983 . This resulted in a condition starting cooler than the base case over a longer period of time, with a later increase to a lower temperature than the base case and with the same cooling time. The temperature histories used are shown in Figure 4-5. The result was slightly cooler soil temperatures around the tank. These temperatures were input into the upper bound case, with all other parameters being held constant between the two cases, and the problem was run. The result showed predicted vertical waste temperatures that were very slightly cooler than the original case. These results are shown in Figure 4-6. 
Figure 4-5. Comparison of Base and Trial Case Temperature Histories.

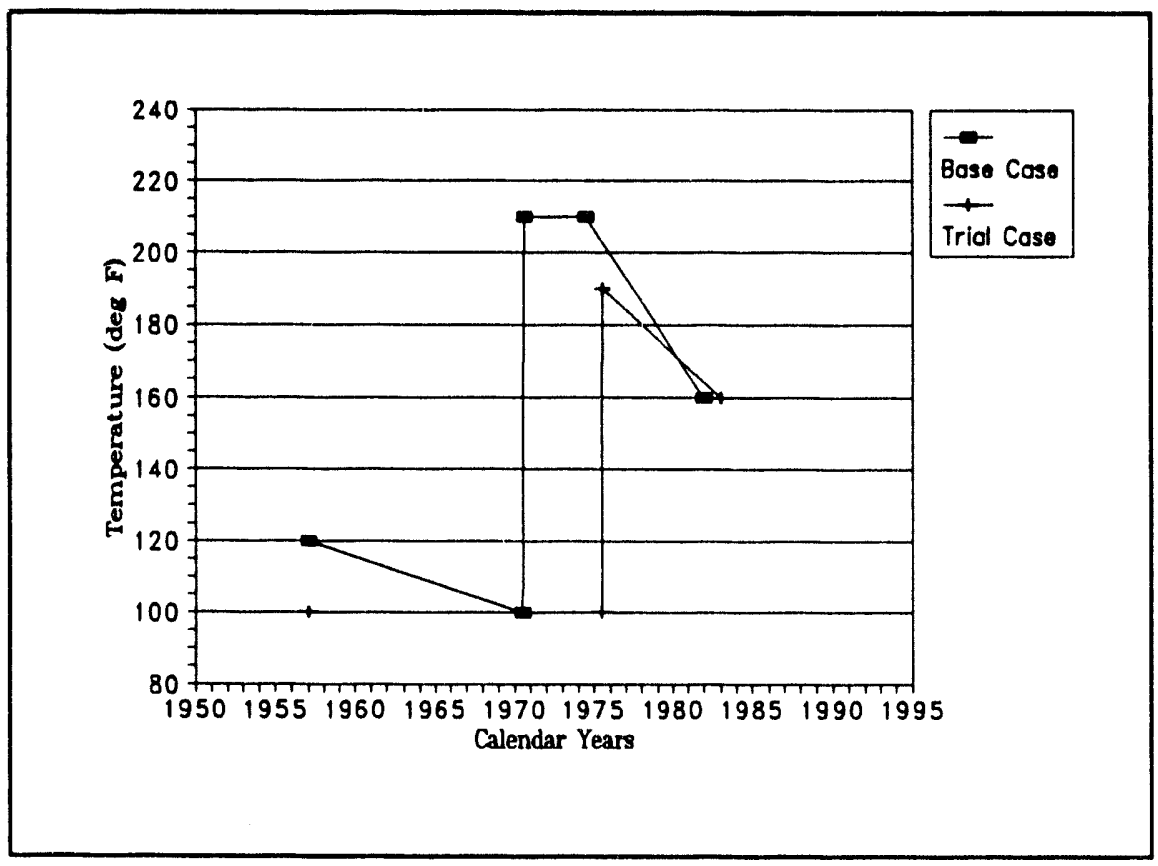

Figure 4-6. Comparison of Base and Trial Case Final Results.

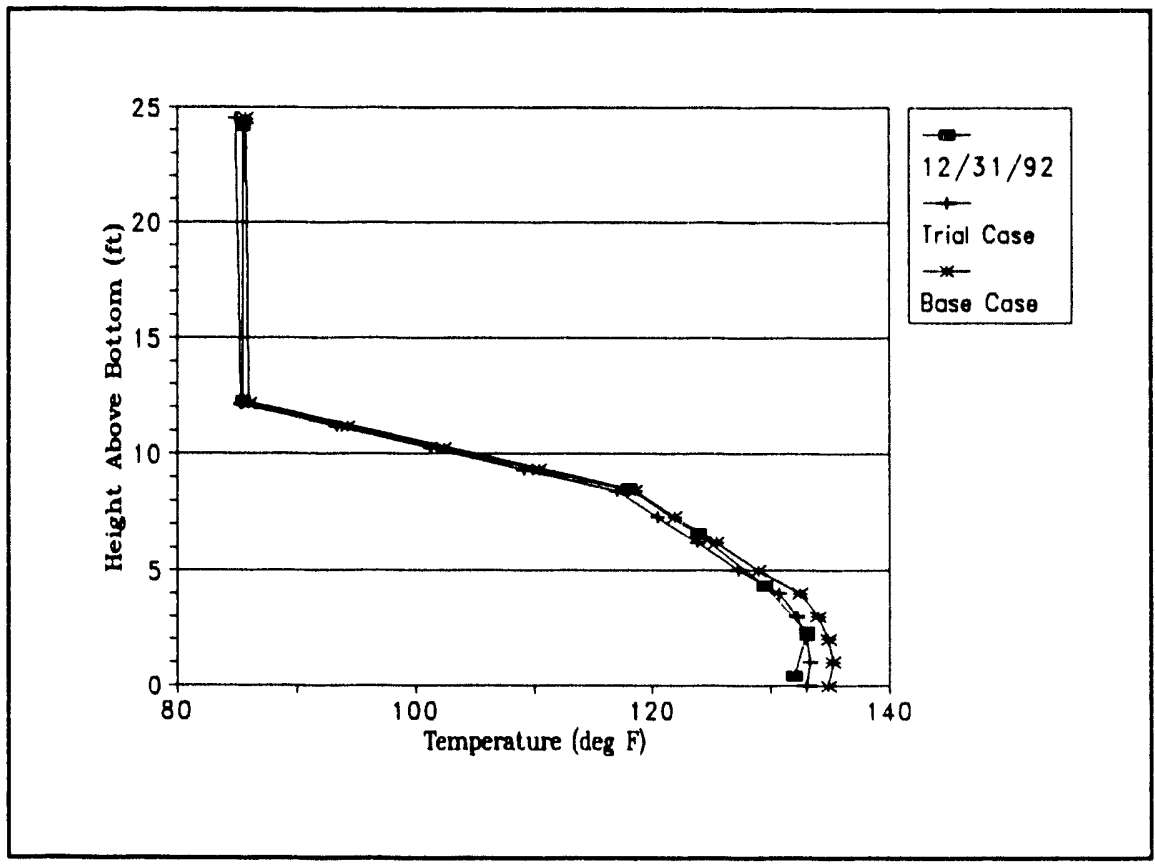


The heat load for the tank under the new initial temperature was predicted and found to be less than $150 \mathrm{~W}$ higher. This is not enough difference to be reasonable. The results of the comparison of the two analyses showed that considerable differences can exist between the actual and estimated temperature histories of the tank and still provide a good prediction of heat load. 
This page intentionally left blank. 


\subsection{ANALYSIS OF TANK 241-BY-104}

\subsection{MODEL OF TANK}

A model of the physical layout of Tank 241-BY-104 was created for the HEATING7 code. This model has been described in Section 3.0. The parameters used for the model are shown below.

$$
\begin{gathered}
\text { Damp Soil Conductivity, Upper bound }=1.008 \mathrm{~W} / \mathrm{m}-{ }^{\circ} \mathrm{C} \\
\text { Dry Soil Conductivity, Upper Bound }=0.696 \mathrm{~W} / \mathrm{m}-{ }^{\circ} \mathrm{C} \\
\text { Damp Soil Conductivity, Lower Bound }=0.589 \mathrm{~W} / \mathrm{m}-{ }^{\circ} \mathrm{C} \\
\text { Dry Soil Conductivity, Lower Bound }=0.435 \mathrm{~W} / \mathrm{m}-{ }^{\circ} \mathrm{C} \\
\text { Concrete Conductivity }=0.935 \mathrm{~W} / \mathrm{m}-{ }^{\circ} \mathrm{C}
\end{gathered}
$$

The dry soil under the tank was modeled in two layers. The first layer was immediately under the tank, $3.90 \mathrm{~m}(12.8 \mathrm{ft})$ thick and $11.43 \mathrm{~m}(37.50 \mathrm{ft})$ in radius. The second layer was under the first, with a thickness of $8.29 \mathrm{~m}(27.20 \mathrm{ft})$ and a radius of $9.55 \mathrm{~m}(31.33 \mathrm{ft})$. The rest of the soil regions around the tank were considered damp. Appropriate conductivity values were assigned to the two types of soil depending upon the case being analyzed. The layout of the model is shown in Figure 3-1.

\subsection{ANALYSIS}

The analysis was conducted in two phases. Phase I developed the soil temperature distribution around the tank, and Phase II used that distribution to predict the heat load of the tank. The two-phase method was necessary because the HEATING7 code does not allow dimensional changes in a model during a run, even during restarts. To describe the change in tank contents before and after saltwell pumping requires a change in the dimensions of the tank contents and changes in the region properties. Because this cannot be adequately handled by special subroutines created for this purpose, it was necessary to create two different tank models.

\subsubsection{Phase I}

The purpose of the Phase I analysis is to determine the temperature distribution of the soil surrounding the tank at the time of saltwell pumping. This temperature distribution will be used as an initial condition for the Phase II analysis, which will determine the heat load of the tank. The unknown parameters in the Phase I analysis were the conductivities of the saltcake, sludge, liquid in the tank, and the heat load of the tank. The following paragraphs explain how these parameters were developed. 
5.2.1.1 Development of Heat Load. The fill/transfer history data of the tank were obtained and plotted to view the levels of solids and liquid in the tank with time. The temperature data available was also obtained and plotted with time. These plots are shown as Figures 5-1 and 5-2.

Figure 5-1. Waste Contents History of Tank 241-BY-104.

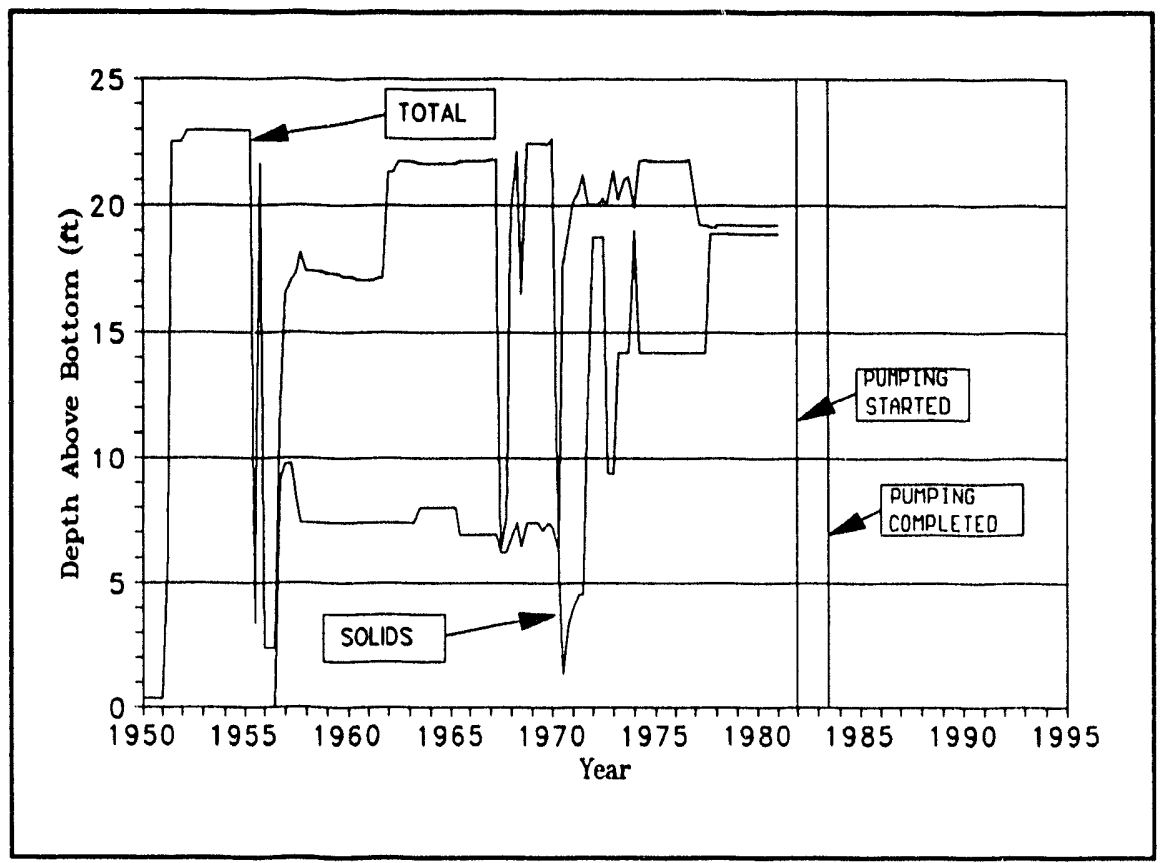

The vertical temperature data for the tank contents in 1982, just prior to saltwell pumping, is shown in Table 5-1.

The February data appears to be high. If $6^{\circ} \mathrm{F}$ are subtracted from all February temperatures, the results fit with the other data very well. These data manipulations are justified by the knowledge that the temperature error is probably constant, and in only one direction.

A plot of these data is shown as Figure 5-3. 
Figure 5-2. Temperature History of Tank 241-BY-104.

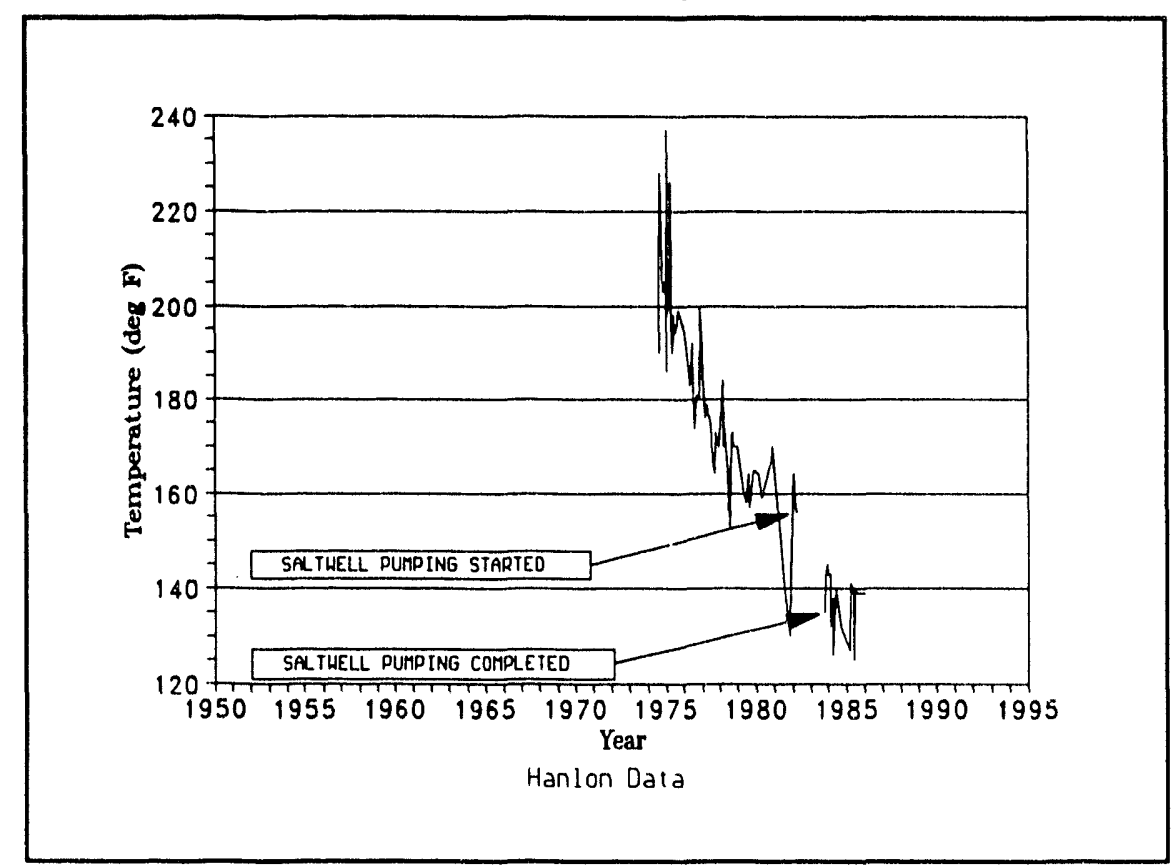

Table 5-1. Vertical Temperature Data for 1982 Temperatures in Degrees F.

\begin{tabular}{||l|c|c|c|c|c|c|c|c|c|c|c|c||}
\hline T/C \# & $\# 1$ & $\# 2$ & $\# 3$ & $\# 4$ & $\# 5$ & $\# 6$ & $\# 7$ & $\# 8$ & $\# 9$ & $\# 10$ & $\# 11$ & $\# 12$ \\
\hline Jan & 158 & 159 & 155 & 147 & 137 & 130 & 122 & 118 & 115 & 96 & 78 & 78 \\
\hline Feb & 164 & 164 & 159 & 151 & 142 & 134 & 127 & 123 & 120 & 105 & 88 & 87 \\
\hline Mar & 155 & 156 & 151 & 144 & 134 & 129 & 120 & 115 & 112 & 96 & 81 & 80 \\
\hline Feb-6 & 158 & 158 & 153 & 145 & 136 & 128 & 121 & 117 & 114 & 99 & 82 & 81 \\
\hline Avg & 157 & 158 & 153 & 145 & 136 & 128 & 121 & 117 & 114 & 97 & 80 & 80 \\
\hline
\end{tabular}


Figure 5-3. Vertical Temperature Data, Early 1982.

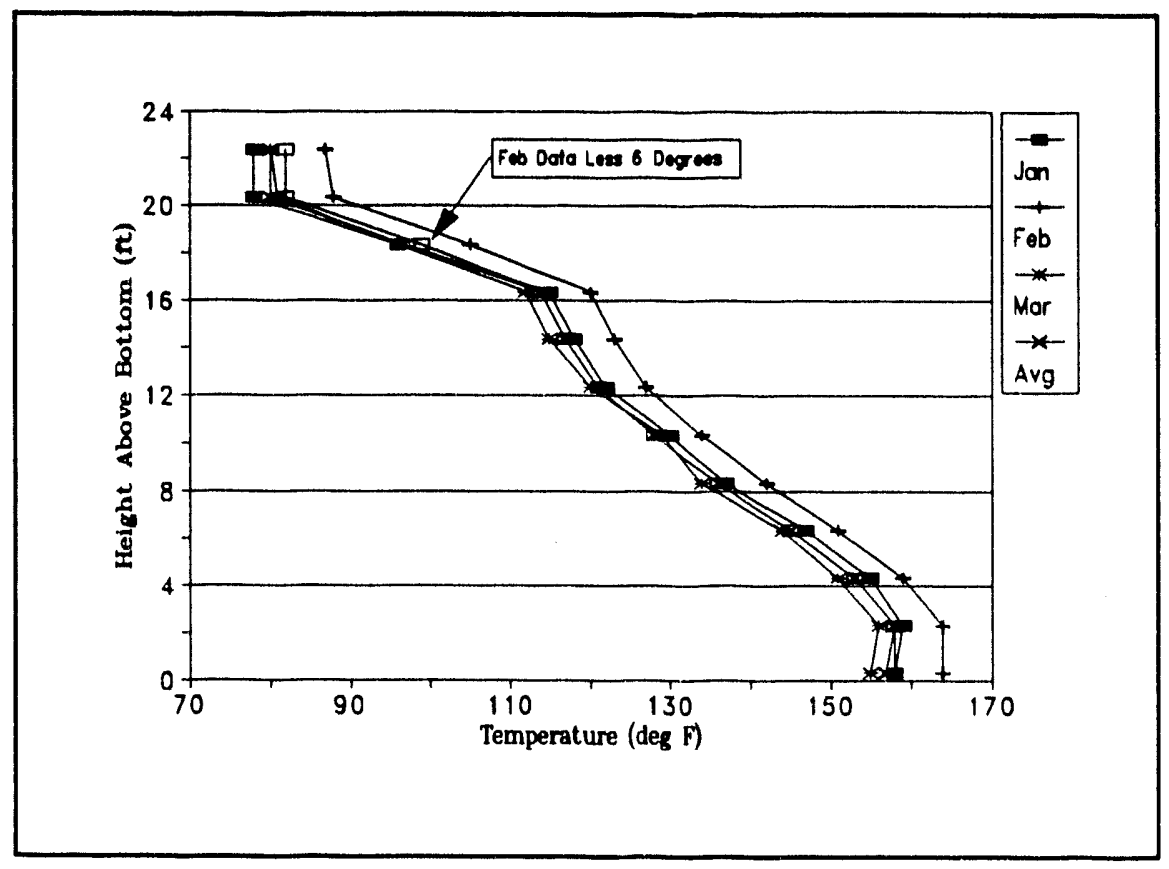

This plot shows an interesting picture. The greatest temperature gradient is at the top, followed by a very low gradient, then a larger one. If there was liquid on top of a crystalline saltcake layer which in turn was on top of a sludge, one would expect the lowest gradient to be on the top and the highest gradient to be just below that. The data indicate that the saltcake is above the liquid layer, which is above the sludge. This configuration would help explain why photographs of the saltwell-pumped tanks show such a great collapse of the saltcake layer onto the sludge.

The half-lives for the two primary heat producing radionuclides are:

$$
\begin{aligned}
{ }^{137} \mathrm{Cs} & =30.17 \text { years } \\
{ }^{90} \mathrm{Sr} & =29.1 \text { years }
\end{aligned}
$$

To simplify the analysis a half-life of 30 years will be used for the heat generation in the model. Using the equation

$$
0.5=\exp (- \text { lambda } * \text { half-life }),
$$


the decay constant, lambda, equates to $2.6357 \times 10^{-6}$ per hour. The time period studied is from 1 January 1957 to 30 June 1983, a period of 26.5 years. The decay factor over this time period is

$$
\mathrm{N} / \mathrm{N}_{\mathrm{o}}=\exp \left(-2.6357 \times 10^{-6} * 232299\right)
$$

which is 0.5421 .

In 1975-76 an assay was made of samples of supernate and solids taken from Tank 241-BY-104. The results of this assay were reported in a letter from J. E. Horton to W. R. Christensen dated March 16, 1976, and are listed as follows.

$$
\begin{aligned}
& \text { supernate }{ }^{137} \mathrm{Cs} \text { of } 5.30 \times 10^{5} \mu \mathrm{Ci} / 1 \\
& \text { supernate }{ }^{90} \mathrm{Sr} \text { of } 2.01 \times 10^{2} \mu \mathrm{Ci} / 1
\end{aligned}
$$

sludge ${ }^{137} \mathrm{Cs}$ of $4.40 \times 10^{5} \mu \mathrm{Ci} / 1$ generating $2.11 \times 10^{-3} \mathrm{~W} / 1$ sludge ${ }^{90} \mathrm{Sr}$ of $1.74 \times 10^{5} \mu \mathrm{Ci} / 1$ generating $1.18 \times 10^{-3} \mathrm{~W} / 1$

Assuming that the heat generated in the supernate per disintegration is the same as that generated in the sludge, the heat generated in the supernate is $2.54 \times 10^{-3} \mathrm{~W} / 1$, in 1976 , assumed to be January 1976. In 1957 the heat would be

$$
2.54 \times 10^{-3} / \exp \left(-2.56357 \times 10^{-6} * 19 * 8766\right)=3.90 \times 10^{-3} \mathrm{~W} / 1 \text {. }
$$

Since there is no definite statement in the report what the solids were, it does not seem advisable to try to develop a tank heat load based on the solids data.

The volume of the waste within the tank after saltwell pumping has been determined in a previous analysis (McLaren 1991). The heights of the waste were determined to be $2.56 \mathrm{~m}$ $(8.4 \mathrm{ft})$ of sludge topped by $1.14 \mathrm{~m}(3.73 \mathrm{ft})$ of saltcake. The heights of the waste before pumping indicated by Figure $5-3$ are $3.69 \mathrm{~m}(12.1 \mathrm{ft})$ for the sludge, $1.27 \mathrm{~m}(4.17 \mathrm{ft})$ for the

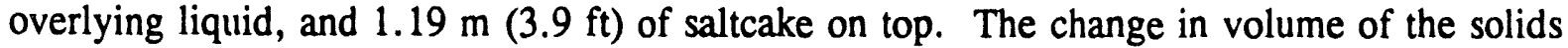
can be accounted for by removing the liquid within them. As the liquid was pumped out, the volume of solids decreased.

The tank model was configured to include the waste within it. The waste levels were as shown below.

$$
\begin{array}{ll}
\text { Elevation of saltcake top } & =7.54 \mathrm{~m}(25.44 \mathrm{ft}) \\
\text { Elevation of saltcake/liquid interface } & =8.94 \mathrm{~m}(29.34 \mathrm{ft}) \\
\text { Elevation of liquid/sludge interface } & =10.21 \mathrm{~m}(33.51 \mathrm{ft}) \\
\text { Elevation of bottom of sludge } & =13.91 \mathrm{~m}(45.64 \mathrm{ft})
\end{array}
$$

The interior of the waste tank model is shown in Figure 5-4. 
Figure 5-4. Model of Tank 241-BY-104 with Waste.

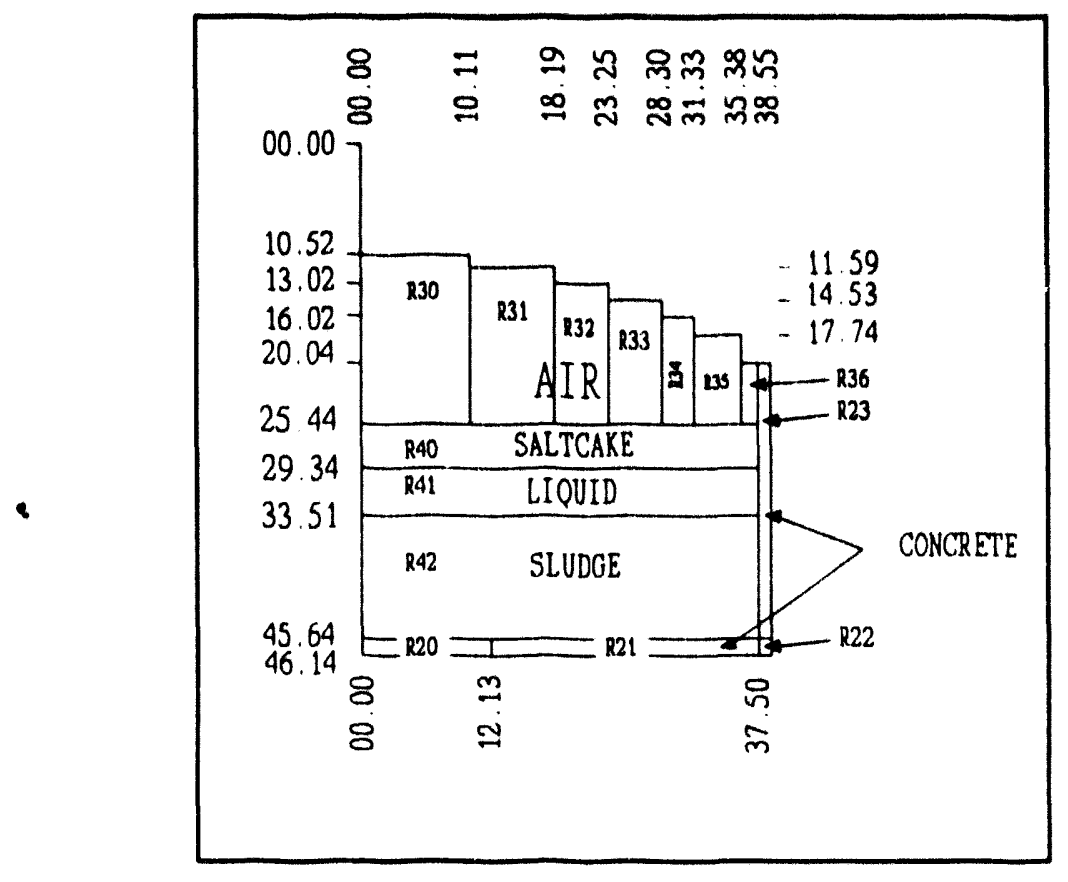

The amount of liquid within the tank was determined by calculating the differences in the volume of sludge and saltcake before and after saltwell pumping.

$$
\begin{aligned}
(3.9-3.73) * 37.5^{2 *} \mathrm{pi} & =751 \mathrm{ft}^{3}(\text { Region 40) } \\
(4.17) * 37.5^{2 *} \mathrm{pi} & =18,422 \mathrm{ft}^{3}(\text { Region 41) } \\
(12.1-8.4) * 37.5^{2 *} \mathrm{pi} & =16,346 \mathrm{ft}^{3}(\text { Region 42) } \\
\text { Total } & =35,519 \mathrm{ft}^{3}
\end{aligned}
$$

$35,519 \mathrm{ft}^{3}$ is $1,005,898$ liters. Thus, the heat load of the liquid in 1957 was then determined to be

$$
1,005,898 * 3.90 \times 10^{3}=3.92 \mathrm{~kW}(13,340 \mathrm{Btu} / \mathrm{h}) .
$$

This heat load is then placed in the various regions of the tank in proportion to the amount of liquid in them. The saltcake is considered to have no heat generation within the solid portion. With the temperature data available, there is no way to verify this assumption or to determine any heat load should one exist. Therefore, the saltcake will have a heat load due only to the entrained liquid. Thus, the heat loads of the various waste regions from the liquid are:

$$
\begin{aligned}
& \text { Region } 40=0.08 \mathrm{~kW} \\
& \text { Region } 41=2.04 \mathrm{~kW} \\
& \text { Region } 42=1.81 \mathrm{~kW}
\end{aligned}
$$


The heat load due to solids in the sludge (in Region 42) was calculated by the following method. The heat load of the tank in 1993 was assumed to be $2.198 \mathrm{~kW}(7,500 \mathrm{Btu} / \mathrm{h})$, a value determined from previous analysis (McLaren 1991). This heat load is assumed to be totally from the solid component of the waste. This value was then calculated for 1957, the beginning of the time period studied.

$$
2.198 / \exp \left(-2.6357 \times 10^{-6 * 315576)}=5.050 \mathrm{~kW}(17,230 \mathrm{Btu} / \mathrm{h})\right.
$$

This value was added to the $1.805 \mathrm{~kW}(6,160 \mathrm{Btu} / \mathrm{h})$ in Region 42 for a total of $6.855 \mathrm{~kW}$ in Region 42, bringing the total heat load of the tank in 1957 to $8.973 \mathrm{~kW}$ $(30,620 \mathrm{Btu} / \mathrm{h})$. This heat load was allowed to decay at a 30 -year half-life during the duration of the problem.

5.2.1.2 Development of Conductivities. In order to determine the waste conductivities during the period 1957 to 1983 , the waste volume was held constant; in other words, no attempt was made to model the changing waste level caused by the tank's fill/transfer history.

The problem was started with the tank contents at $71.11^{\circ} \mathrm{C}\left(160^{\circ} \mathrm{F}\right)$, and the soil surrounding the tank at $12.22^{\circ} \mathrm{C}\left(54^{\circ} \mathrm{F}\right)$ at the surface, changing linearly to $12.78^{\circ} \mathrm{C}$ $\left(55^{\circ} \mathrm{F}\right)$ at the water table. The values of the conductivity of the soils surrounding the tank were the averages of the upper and lower bound values previously determined; i.e., 0.796 $\mathrm{W} / \mathrm{m}-{ }^{\circ} \mathrm{C}\left(0.46 \mathrm{Btu} / \mathrm{h}-\mathrm{ft}-{ }^{\circ} \mathrm{F}\right)$ for damp soil and $0.554 \mathrm{~W} / \mathrm{m}-{ }^{\circ} \mathrm{C}\left(0.32 \mathrm{Btu} / \mathrm{h}-\mathrm{ft}-{ }^{\circ} \mathrm{F}\right)$ for dry soil. In this initial part of the analysis, no attempt was made to model actual conditions, as only approximate values of waste conductivity were needed.

A series of computer predictions was run, varying the conductivity of the waste and liquid until agreement was made with the vertical temperature data of the waste in 1982 . It was found necessary to add a ventilation heat loss to the tank to match the temperature data. This ventilation loss was also varied to reach a match with the data. The ventilation heat loss required was found to be $2.198 \mathrm{~kW}(7,500 \mathrm{Btu} / \mathrm{h})$ over the entire duration of the problem. A good match with the data was obtained using the parameters shown in Table 5-2. The predicted-versus-data vertical temperature match is shown in Figure 5-5.

Table 5-2. Initial Parameters for Phase I.

\begin{tabular}{||l|r|}
\hline Heat load (initial) & $8.92 \mathrm{~kW}$ \\
\hline Ventilation loss & $2.20 \mathrm{~kW}$ \\
\hline Saltcake conductivity & $.554 \mathrm{~W} / \mathrm{m}-{ }^{\circ} \mathrm{C}$ \\
\hline Liquid conductivity & $2.596 \mathrm{~W} / \mathrm{m}-{ }^{\circ} \mathrm{C}$ \\
\hline Sludge conductivity & $.779 \mathrm{~W} / \mathrm{m}-{ }^{\circ} \mathrm{C}$ \\
\hline
\end{tabular}


Figure 5-5. Predicted Vertical Temperatures versus Data, 1982.

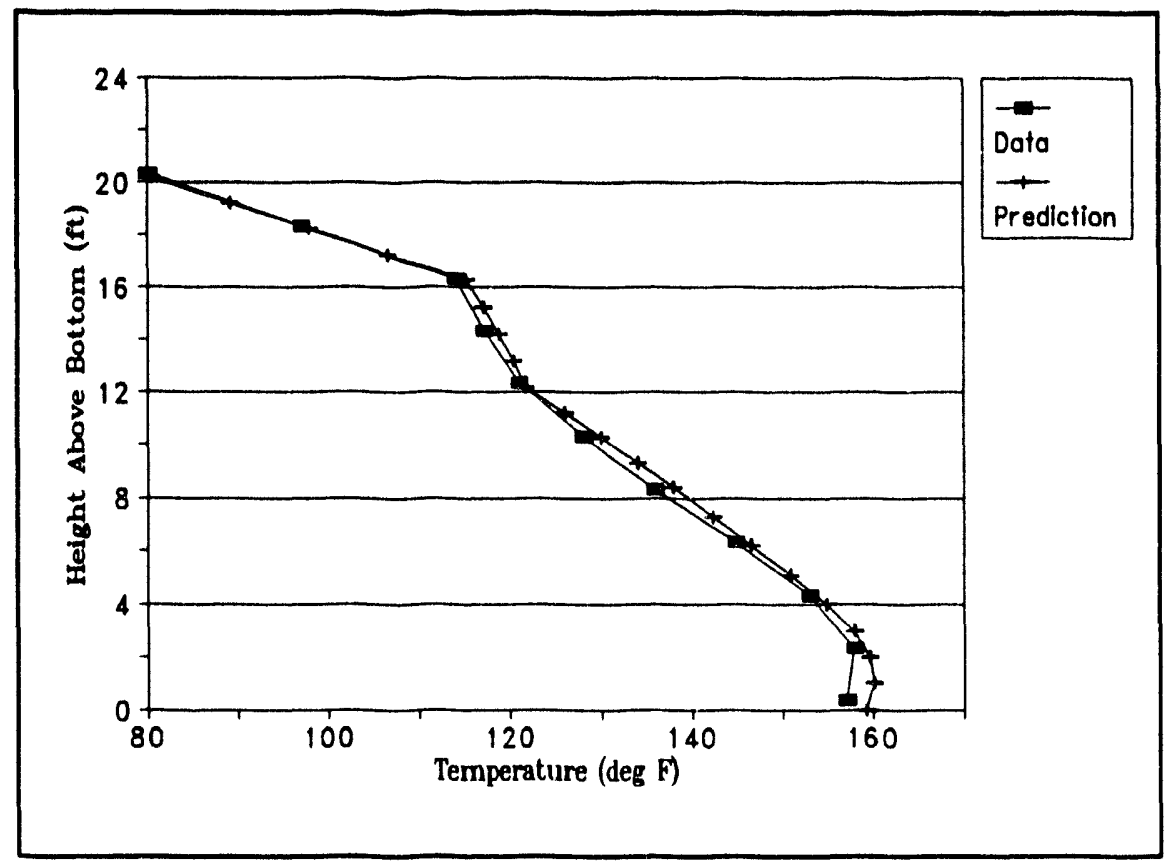

5.2.1.3 Development of Soil Temperatures. This part of Phase I creates a temperature map of the soil surrounding the waste storage tank. The tank's fill/transfer history and the available temperature history are used to create an approximation of the tank temperature history from 1957 to 1982, the time saltwell pumping would have commenced. This history is duplicated by the computer model by starting a transient problem with an initial heat load, multiplying the liquid component of the heat load by a factor at the time the tank was placed into ITS service, and putting a ventilation heat loss into the model at this time to cool the tank. These parameters are altered to get the resulting predicted maximum temperatures to match salient points of the estimated maximum temperature history. The heat loads required to make this match co not correspond to the tank's actual heat load over time, but the intent is to match the tank maximum temperature, not the heat load. This is true especially over the period the tank was placed into ITS service, as there is no way to reproduce the temperatures created by adding thermally hot liquids to the tank except by putting a large heat load into the model during this period.

The estimated maximum temperature history was created by using the tank's fill/transfer history and temperature history. The tank was considered to have started with waste at $48.9{ }^{\circ} \mathrm{C}$ in January 1957 which cooled to $37.8^{\circ} \mathrm{C}$ by June 1970 . At this point the tank went into ITS service and the temperature went up to $98.9^{\circ} \mathrm{C}$ in July 1970. It is not possible for the model to make such a sharp rise in temperature, so the point used to match was January 1972. The temperature held constant until June 1974 , then slowly dropped to $71.1^{\circ} \mathrm{C}$ by January 1982 . This estimated history is shown in Figure 5-6. 
Figure 5-6. Temperature versus Time for Tank 241-BY-104Points Noted for Analysis.

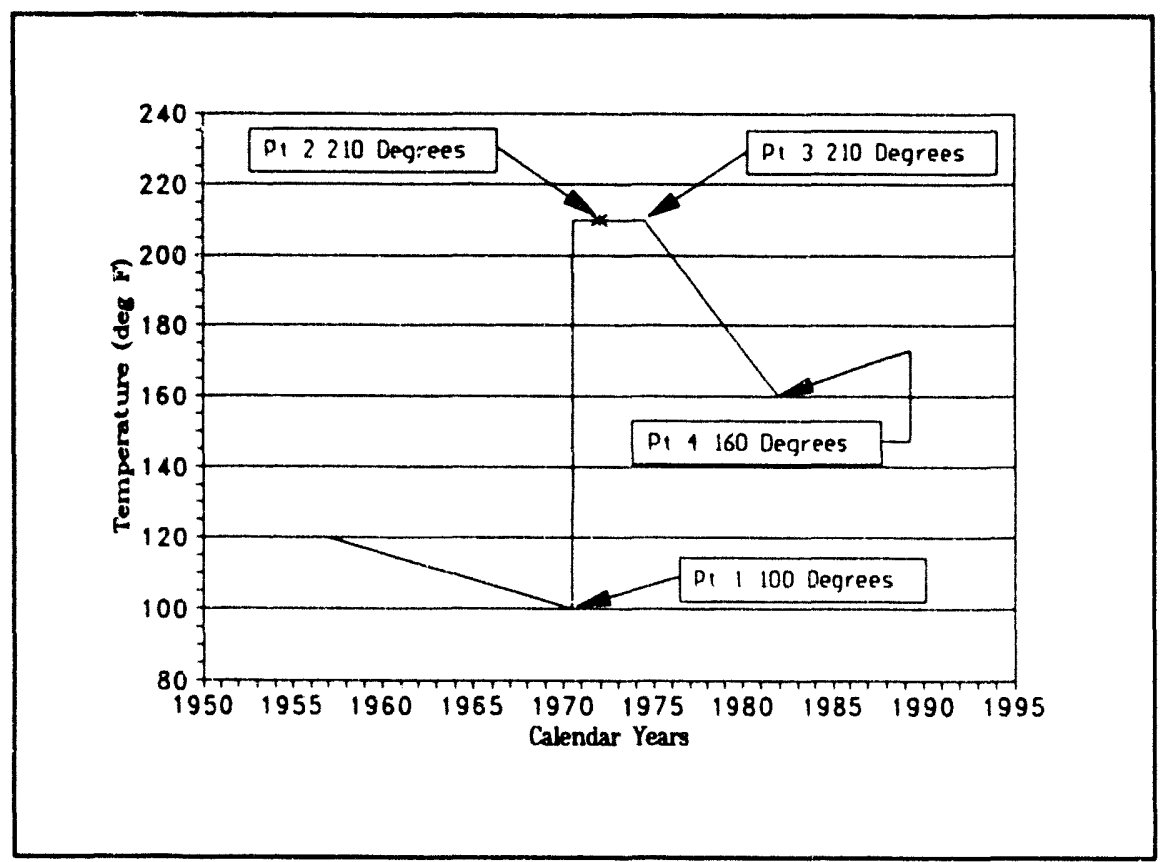

The heat load of the sludge was altered to match Point $1\left(37.78^{\circ} \mathrm{C}\left[100^{\circ} \mathrm{F}\right]\right)$, a multiple was introduced to the supernate heat load to match Point 2 and Point $3\left(98.9^{\circ} \mathrm{C}\left[210{ }^{\circ} \mathrm{F}\right]\right)$, and the ventilation heat loss was applied from 1970 to 1982 to match Point $4\left(71.11^{\circ} \mathrm{C}\left[160^{\circ} \mathrm{F}\right]\right)$. The heat contributed by the liquid was 0 from 1957 to 1975 . This is a reasonable assumption, as the information in 1976 pertained to the supernate from the ITS service, not the liquid load prior to that time. The parameters that fit these criteria were as shown in Table 5-3.

Table 5-3. Parameter Values for Basic Fit.

\begin{tabular}{||l|l||}
\hline Sludge heat load & $3.517 \mathrm{~kW}$ in 1957 \\
\hline Liquid heat load & 0 in $1957,2.518 \mathrm{~kW}$ in July 1970 \\
\hline Liquid heat load multiple & 0 in 1957,6 in July 1975 \\
\hline Ventilation heat loss & 0 in $1957,2.345 \mathrm{~kW}$ in July 1970 \\
\hline
\end{tabular}

The temperatures of the soil around the tank which were predicted for 1982 are shown in Figures 5-7 and 5-8. 
Figure 5-7. Vertical Temperatures at Various Radii.

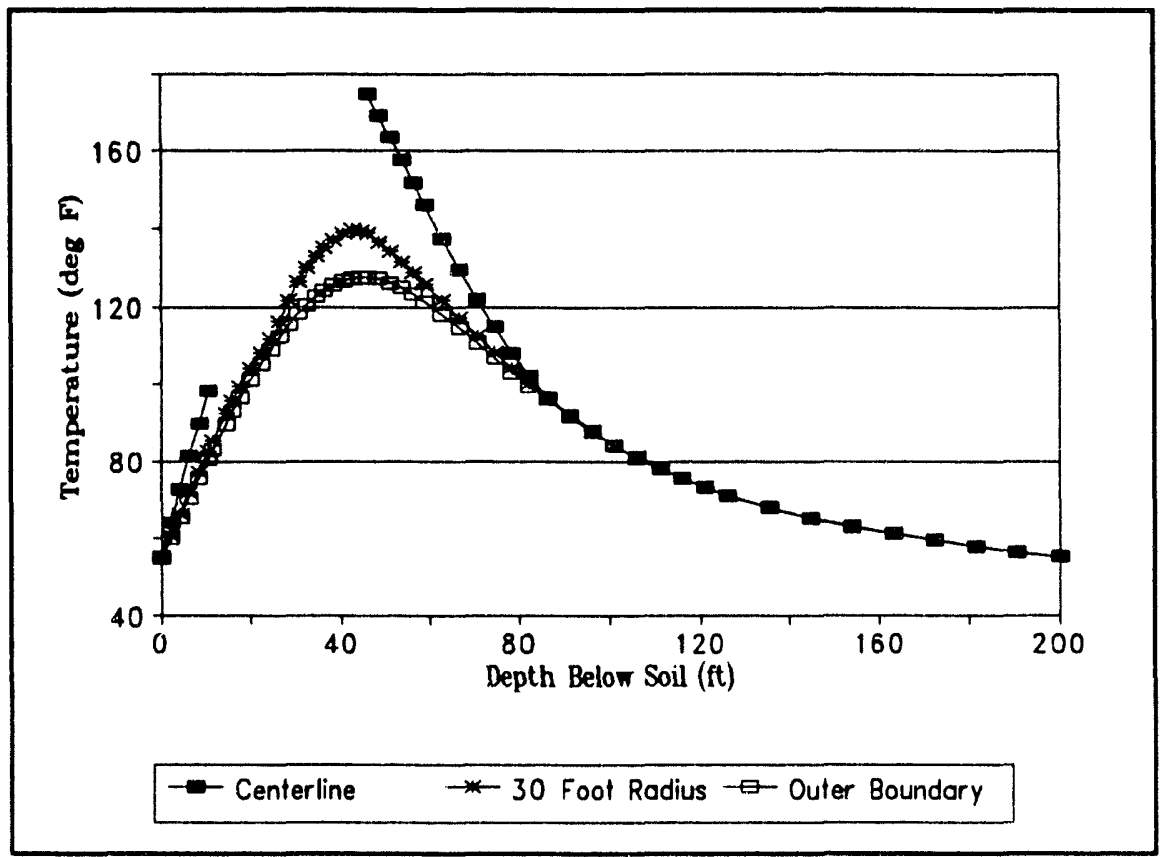

Figure 5-8. Horizontal Temperatures at Various Depths Below Soil Surface.

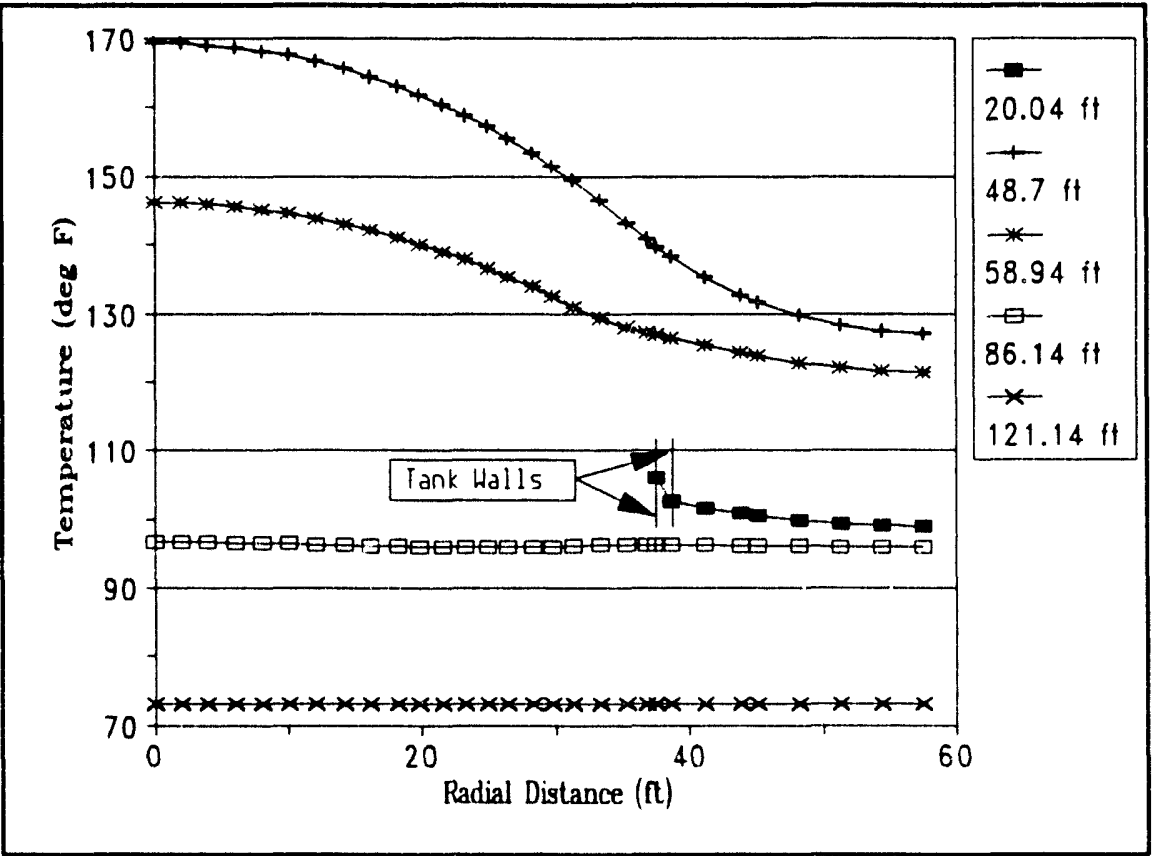


As can be seen from these figures, the horizontal temperature distribution below the 24.38-m (80-ft) depth is isothermal, which simplifies the temperature map greatly. Also, above the tank and at distances greater than the radius of the tank, the horizontal temperatures are nearly isothermal (note the 20.04-ft temperature distribution above). The temperatures above the tank show a nearly linear vertical distribution.

The conductivities of the soil surrounding the tank were changed to the values determined for the lower bound case, $.588 \mathrm{~W} / \mathrm{m}-{ }^{\circ} \mathrm{C}$ for the damp soil and $.434 \mathrm{~W} / \mathrm{m}-{ }^{\circ} \mathrm{C}$ for the dry soil. The problem was run again and the temperature map generated. Then the soil conductivities were changed again, to the values for the upper bound, and the process was repeated. Thus, at the end of Phase I the temperature maps for the soil surrounding the tank for both upper and lower bounds have been generated. The comparison between the two temperature distributions predicted for 1982 is shown in Figure 5-9.

Figure 5-9. Vertical Temperature Distribution for Upper and Lower Bound Cases.

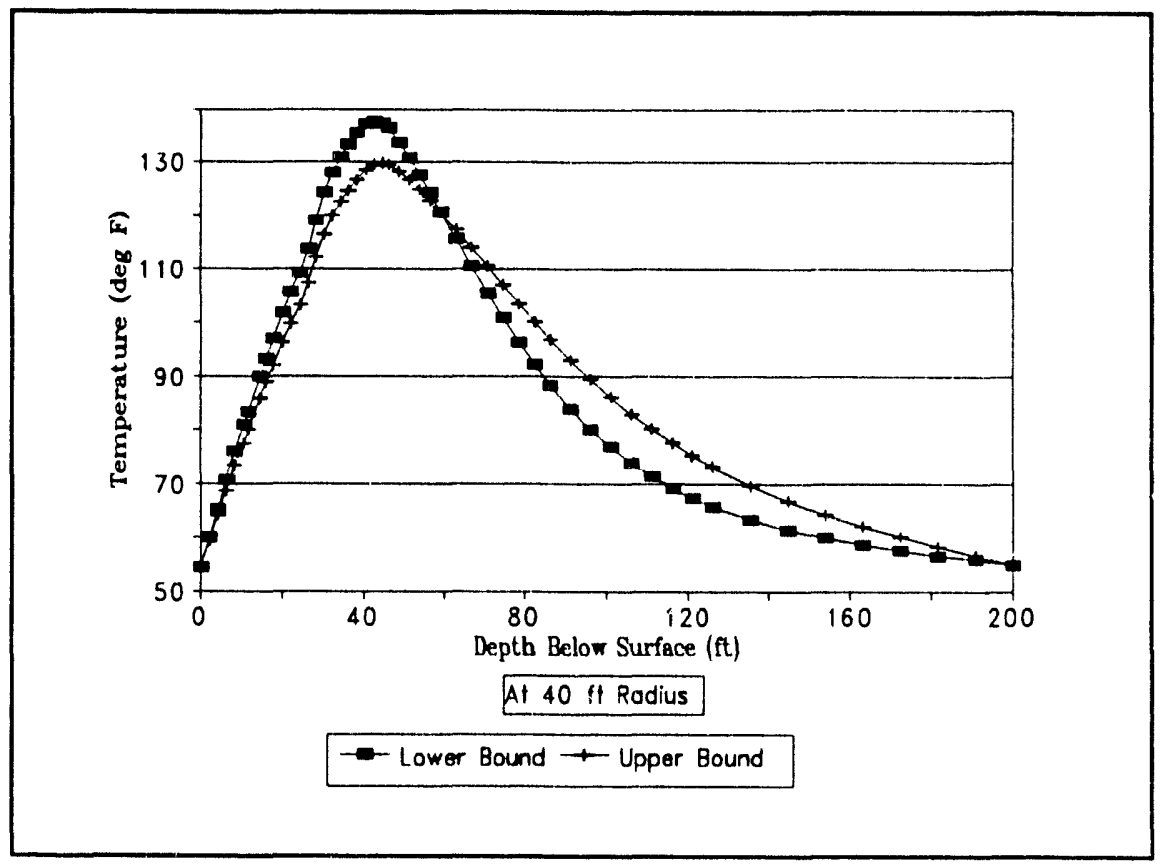

\subsubsection{Phase II}

The purpose of the Phase II analysis is to predict the heat load of the tank. This phase uses a transient analysis beginning from the completion of saltwell pumping to the present. It requires that the temperatures of both the soil surrounding the tank and the tank contents at the 
beginning of the transient be known. The temperature of the tank contents at the start of the transient is known from data taken at that time. Development of the soil temperature distribution was the purpose of the Phase I analysis.

\subsubsection{Initial Conditions}

5.2.2.1.1 Soil Temperature Map. The temperature map of the lower bound condition was input into the model as an initial condition. This was done by inputting the following representative areas of the temperature distribution as a series of functions normalized to a specific temperature.

1. The vertical temperature distribution along the centerline from the tank bottom to the water table

2. The vertical temperature distribution from the surface to a depth of $27.78 \mathrm{~m}$ $(91.14 \mathrm{ft})$ at the $11.85-\mathrm{m}(38.88-\mathrm{ft})$ radius

3. The horizontal temperature distribution from the tank wall to the outer boundary at the $11.07-\mathrm{m}(36.31-\mathrm{ft})$ depth

4. The horizontal temperature distribution from the centerline to the outer boundary at the 14.84-m (48.70-ft) depth

5. The horizontal temperature distribution from the centerline to the outer boundary at the $19.15-\mathrm{m}(62.83-\mathrm{ft})$ depth

6. The horizontal temperature distribution below the $27.78-\mathrm{m}(91.14-\mathrm{ft})$ depth was considered isothermal.

7. The temperature distribution above the tank was considered linear from the tank top to the soil surface.

Functions for these distributions were created by normalizing both vertical distributions to the temperature of the node located just below the tank bottom at the centerline. For the lower bound case this temperature is $75.47^{\circ} \mathrm{C}\left(167.84^{\circ} \mathrm{F}\right)$, and for the upper bound case it is $72.73{ }^{\circ} \mathrm{C}\left(162.91^{\circ} \mathrm{F}\right)$. The horizontal distributions were normalized to the temperature of the node at the intersection of the horizontal and vertical temperature distributions. This method was used to allow for ease in changing the values of the temperatures in the distribution, a consideration that will be used later.

The code uses these functions to determine an initial temperature at a node by multiplying the horizontal function value at the node location by the vertical function value at the same location by the normalization factor (if one is used). In this manner, over 5,000 nodes can be mapped with only a few functions, although the map will not be an exact duplicate of the map created in Phase I. 
With these distributions in place, results of the Phase I computations are used to determine the normalization temperature. For the lower bound, the maximum temperature calculated was $76.0^{\circ} \mathrm{C}\left(168.77^{\circ} \mathrm{F}\right)$. It should have been $71.1^{\circ} \mathrm{C}\left(160^{\circ} \mathrm{F}\right)$ skewed $1.67^{\circ} \mathrm{C}\left(3^{\circ} \mathrm{F}\right)$ high or $72.8^{\circ} \mathrm{C}\left(163^{\circ} \mathrm{F}\right)$. The error is $3.22^{\circ}$ high. This error is subtracted from the value computed for the centerline just under the tank, $75.47^{\circ} \mathrm{C}$. The result, $22.4^{\circ} \mathrm{C}\left(72.26^{\circ} \mathrm{F}\right)$ is the normalization factor for the lower bound analysis. For the upper bound, the maximum calculated temperature was $73.93^{\circ} \mathrm{C}\left(165.07^{\circ} \mathrm{F}\right)$. It should be $71.11^{\circ} \mathrm{C}\left(160^{\circ} \mathrm{F}\right)$ skewed $1.67^{\circ}$ low, or $69.44^{\circ} \mathrm{C}\left(157^{\circ} \mathrm{F}\right)$. The error is $4.48^{\circ}$ high. This value is subtracted from the temperature computed for the centerline just under the tank, $72.73{ }^{\circ} \mathrm{C}$. The result, $68.24{ }^{\circ} \mathrm{C}$ $\left(154.8^{\circ} \mathrm{F}\right)$ is the normalization factor for the upper bound analysis. This technique is not exact, but because the maximum temperature in the tank is very close to the temperature of the soil just under the tank at the centerline, it introduces very little error. The largest temperature error introduced is in the vicinity of the water table, but its effect on the problem is very slight because it is so far displaced from the heat source and because of the problem's comparatively short time ( 9 years versus 25.5 years).

5.2.2.1.2 Tank Contents. The model was modified to show the conditions existing after saltwell pumping in 1984. Previous analyses (McLaren 1991) have shown that the sludge within the tank has varying conductivity, estimated to be due to the changing liquid content within the sludge. The sludge has been divided into two regions, called "damp" and "wet" to distinguish between them. The regions inside the tank were modified to show the contents of the tank after saltwell pumping. The tank waste dimensions were taken from (McLaren 1991). The waste levels are as shown below. (Refer also to Figure 5-4.)

$\begin{array}{lc}\text { Elevation of saltcake top } & 10.21 \mathrm{~m}(33.51 \mathrm{ft}) \\ \text { Elevation of saltcake/sludge interface } & 11.35 \mathrm{~m}(37.24 \mathrm{ft}) \\ \text { Elevation of damp/wet sludge interface } & 12.69 \mathrm{~m}(41.64 \mathrm{ft}) \\ \text { Elevation of bottom of sludge } & 13.91 \mathrm{~m}(45.64 \mathrm{ft})\end{array}$

A temperature distribution for the waste was created. Functions for the horizontal temperature distribution for each of the three regions were created by taking the temperature distributions that existed in the waste at the end of the Phase I calculation and normalizing them to the centerline temperature at that level. These distributions were taken at levels that corresponded to levels centered in the three regions created for Phase II, shown above, except that the level for Region 40, the saltcake, was taken just below the surface level to make the surface temperatures more accurate. This method, while not exact, provides a fairly close estimate of the distributions, with the exception of the highest level, as shown in Figure 5-10 by a comparison between the input distribution and the final distribution.

In order to determine if the variance between the input and the computed near-surface temperature distribution would cause an unacceptable error, a run was made with the computed distribution as an initial condition. The resulting difference in the results was less than $.03{ }^{\circ} \mathrm{C}$ $\left(.05^{\circ} \mathrm{F}\right)$ in 1993 . The initial vertical temperature distribution input was the average of the vertical temperature measurements taken around the end of 1983 and the start of 1984. This data is shown in Table 5-4. 
Figure 5-10. Normalized Horizontal Sludge

Temperature Distributions Input versus

Final Calculation for Various Depths

Below Soil Surface.

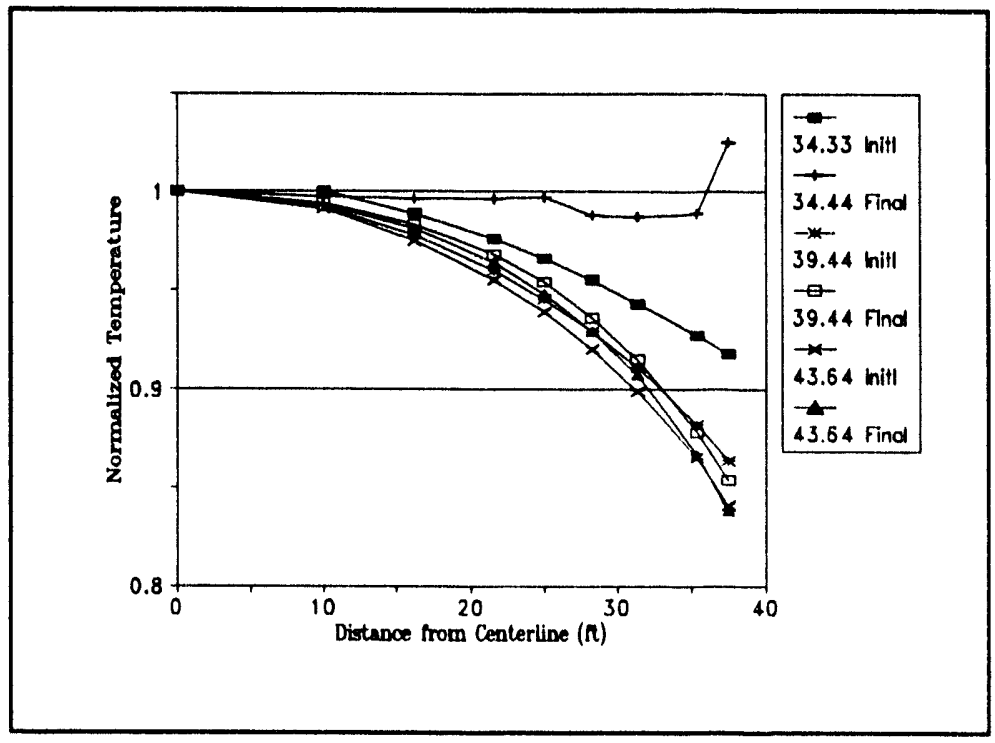

Table 5-4. Temperature Data for Initial Conditions. (Temperatures in Degrees F)

\begin{tabular}{||l|l|l|l|l|l|l||}
\hline & $\mathrm{T} / \mathrm{C} \# 1^{\circ} \mathrm{F}$ & $\mathrm{T} / \mathrm{C} \mathrm{\# 2}{ }^{\circ} \mathrm{F}$ & $\mathrm{T} / \mathrm{C} \mathrm{\# 3}{ }^{\circ} \mathrm{F}$ & $\mathrm{T} / \mathrm{C} \mathrm{\# 4}{ }^{\circ} \mathrm{F}$ & $\mathrm{T} / \mathrm{C} \mathrm{\# 5}{ }^{\circ} \mathrm{F}$ & $\mathrm{T} / \mathrm{C}$ \#6 ${ }^{\circ} \mathrm{F}$ \\
\hline \hline Nov 83 & 144 & 144 & 139 & 129 & 121 & 82 \\
\hline Dec 83 & 144 & 145 & 139 & $149 *$ & 121 & 77 \\
\hline Jan 84 & 143 & 143 & 139 & 129 & 120 & 72 \\
\hline Feb 84 & 143 & 143 & 138 & 127 & 118 & 70 \\
\hline Average & 143 & 144 & 139 & 128 & 120 & 70 \\
\hline Height & $.4 \mathrm{ft}$ & $2.3 \mathrm{ft}$ & $4.3 \mathrm{ft}$ & $6.6 \mathrm{ft}$ & $8.5 \mathrm{ft}$ & $24.2 \mathrm{ft}$ \\
\hline Elevation & $45.24 \mathrm{ft}$ & $43.34 \mathrm{ft}$ & $41.34 \mathrm{ft}$ & $39.04 \mathrm{ft}$ & $37.14 \mathrm{ft}$ & $21.47 \mathrm{ft}$ \\
\hline
\end{tabular}

*The temperature for thermocouple \#4 in December 1983 is considered incorrect. 
Note how the temperature readings for thermocouple \#6 drop with time as the colder winter temperatures penetrate into the tank. The temperature chosen for position $\# 6$ is $21.1^{\circ} \mathrm{C}$ $\left(70^{\circ} \mathrm{F}\right)$ because that is considered more representative of what it should be, without the lag caused by the soil cover over the tank. The computed temperature was around $27.8^{\circ} \mathrm{C}\left(82^{\circ} \mathrm{F}\right)$.

5.2.2.1.3 Results. With these initial conditions, the heat load and conductivities are determined by varying the heat load and conductivities of the waste in the tank until the resulting predicted temperatures at the end of the transient, in 1993, match the data temperature readings for 1993. These data are shown in Table 5-5.

Table 5-5. December 31, 1992 Temperature Data for 241-BY-104. (Temperatures in Degrees F)

\begin{tabular}{||l|l|l|l|l|l|l||}
\hline & T/C \#1 & T/C \#2 & T/C \#3 & T/C \#4 & T/C \#5 & T/C \#6 \\
\hline \hline Temp $\left({ }^{\circ} \mathrm{F}\right)$ & 129 & 130 & 126.5 & 121 & 115 & 82.5 \\
\hline Height (ft) & .4167 & 2.3333 & 4.3333 & 6.5833 & 8.5 & 24.1667 \\
\hline Elev. (ft) & 45.22 & 43.31 & 41.31 & 39.06 & 37.14 & 21.47 \\
\hline
\end{tabular}

When determining the upper bound case, these temperatures are all skewed $3^{\circ}$ low, and for the lower bound case, they are all skewed $3^{\circ}$ high. These skews are to provide the worst case errors within the known error band and thus cause the greatest deviation for the analyses.

The upper and lower bound determinations are made by assuming a heat load at the beginning of the transient (1984) and thermal conductivities for the waste regions, and by running the transient case to 1993 . The resulting temperature predictions at the location of the thermocouple tree $(2.44 \mathrm{~m} \mathrm{[8} \mathrm{ft}$ ] from the centerline) are compared with the data. The heat load can be roughly established by the airspace temperature, and the conductivities by the slope of the vertical temperature plot. There is sufficient interrelation between the two that both parameters must be varied to reach a solution that can be considered fairly unique. The results of the upper and lower bound analyses are shown in Figures 5-11 and 5-12.

The upper bound case predicted temperatures are very close to the data temperatures, which were skewed high.

The lower bound case shows a bracket between $1.465 \mathrm{~kW}(5,000 \mathrm{Btu} / \mathrm{h})$ and $1.612 \mathrm{~kW}$ $(5,500 \mathrm{Btu} / \mathrm{h})$. It does not appear to be wise to attempt a solution closer than $.15 \mathrm{~kW}$ $(500 \mathrm{Btu} / \mathrm{h})$; consequently, the lower bound heat load is considered to be $1.465 \mathrm{~kW}$. Table $5-6$ presents the results of these analyses. 
Figure 5-11. Comparison of Predicted versus Data Temperatures-Tank 241-BY-104 Upper Bound.

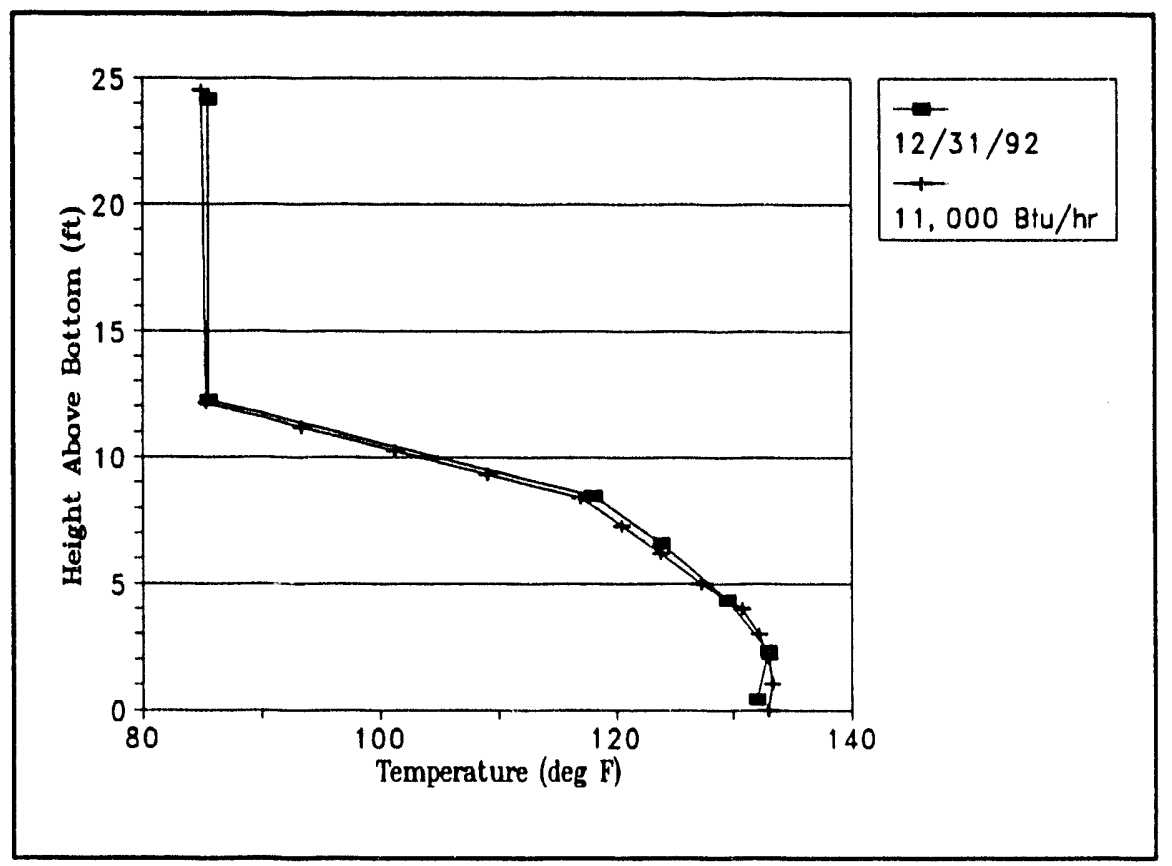

Figure 5-12. Comparison of Predicted versus Data Temperatures-Tank 241-BY-104 Lower Bound.

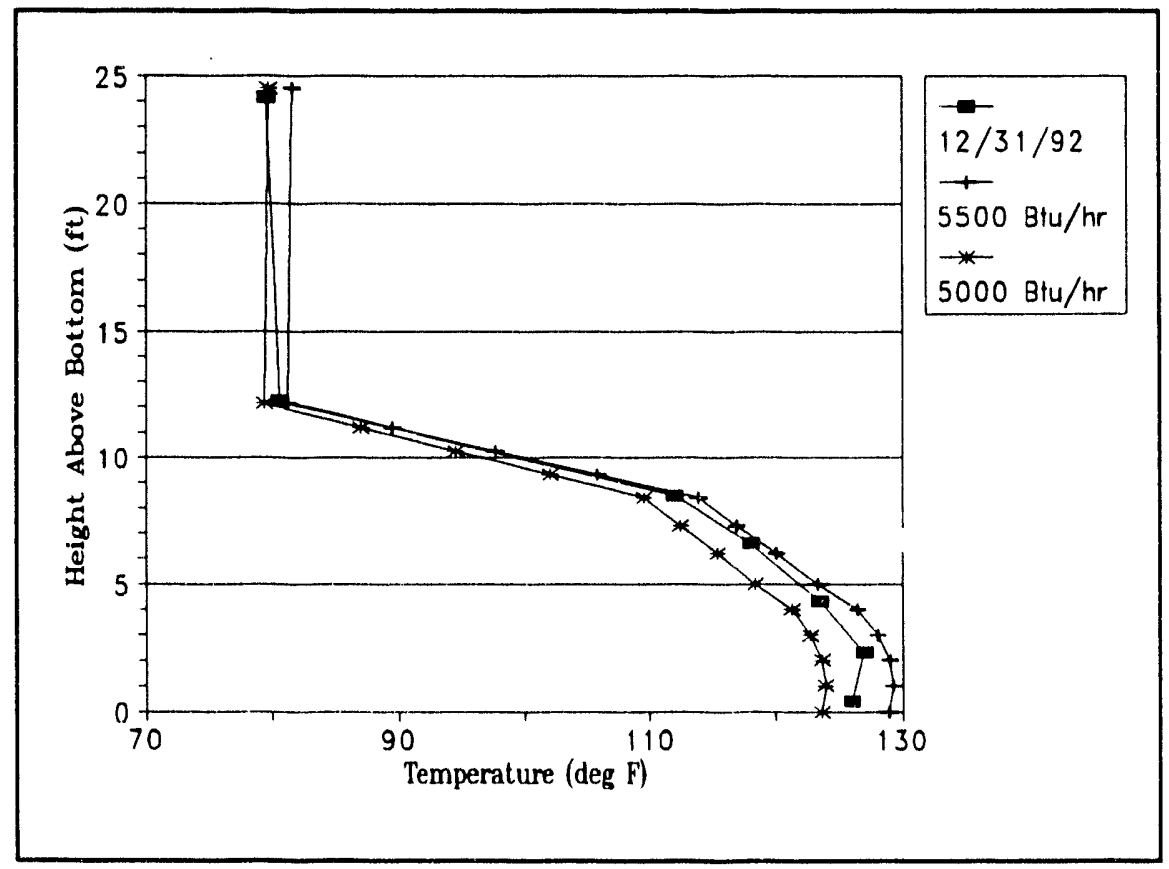


Table 5-6. Results of Upper Bound, Lower Bound, and Median Values.

\begin{tabular}{|l|l|l|l|l||}
\hline \hline & \multicolumn{1}{|c|}{ Heat load } & \multicolumn{1}{|c|}{$\begin{array}{c}\text { Saltcake } \\
\text { conductivity }\end{array}$} & $\begin{array}{c}\text { Upper layer } \\
\text { (damp) } \\
\text { conductivity }\end{array}$ & \multicolumn{1}{|c|}{$\begin{array}{c}\text { Lower layer (wet) } \\
\text { conductivity }\end{array}$} \\
\hline \hline $\begin{array}{l}\text { Upper } \\
\text { Bound }\end{array}$ & $\begin{array}{l}3.224 \mathrm{~kW} \\
(11,000 \mathrm{Btu} / \mathrm{h})\end{array}$ & $.17 \mathrm{~W} / \mathrm{m}-{ }^{\circ} \mathrm{C}$ & $.52 \mathrm{~W} / \mathrm{m}-{ }^{\circ} \mathrm{C}$ & $.78 \mathrm{~W} / \mathrm{m}-{ }^{\circ} \mathrm{C}$ \\
\hline Median & $\begin{array}{l}2.345 \mathrm{~kW} \\
(8,000 \mathrm{Btu} / \mathrm{h})\end{array}$ & $.26 \mathrm{~W} / \mathrm{m}-{ }^{\circ} \mathrm{C}$ & $.74 \mathrm{~W} / \mathrm{m}-{ }^{\circ} \mathrm{C}$ & $1.25 \mathrm{~W} / \mathrm{m}-{ }^{\circ} \mathrm{C}$ \\
\hline $\begin{array}{l}\text { Lower } \\
\text { Bound }\end{array}$ & $\begin{array}{l}1.465 \mathrm{~kW} \\
(5,000 \mathrm{Btu} / \mathrm{h})\end{array}$ & $.35 \mathrm{~W} / \mathrm{m}-{ }^{\circ} \mathrm{C}$ & $.95 \mathrm{w} / \mathrm{m}-{ }^{\circ} \mathrm{C}$ & $1.73 \mathrm{~W} / \mathrm{m}{ }^{\circ} \mathrm{C}$ \\
\hline
\end{tabular}

It is interesting to note that the lower bound value of the heat load of Tank 241-BY-104 is $1.465 \mathrm{~kW}$, which is very close to the $1.162 \mathrm{~kW}(3,965 \mathrm{Btu} / \mathrm{h})$ determined by a previous, less sophisticated model and technique (McLaren 1991). The earlier model and method used a lower value of soil conductivity and a steady-state solution. The lower value of soil conductivity would underpredict the heat load while the steady-state solution would overpredict the heat load. Evidently the soil conductivity has a greater effect on the prediction than the steady-state solution. As a result, other analyses using the same less- sophisticated model and technique will estimate heat load values that will be at the lower bound of the more exact analysis technique used here. 
This page intentionally left blank. 


\subsection{CONCLUSIONS}

The improved model and analysis technique provides a more accurate estimation of the upper and lower bounds of the heat load and thermal characteristics of the ferrocyanide waste storage tanks. While the spread of the bounding values is high, it results from soil conductivity conditions in the farms that are not well defined. With increased knowledge of the moisture content of the soils surrounding the waste storage tanks, the bounding limits will become closer.

As a result of this analysis, a factor can be developed to be applied to an earlier analysis of Tanks 241-BY-105, -106, -108, -110, -111, and 241-C-109 (McLaren 1993). These tanks were analyzed using the earlier, steady-state method, and the results of this new, more accurate method can be roughly applied to them.

The median heat load of Tank 241-BY-104 estimated by this analysis is $2.345 \mathrm{~kW}$ $(8,000 \mathrm{Btu} / \mathrm{h})$ and the previously reported heat load was $1.465 \mathrm{~kW}(5,000 \mathrm{Btu} / \mathrm{h})$. The previous analysis used the steady-state model and a soil conductivity of $.433 \mathrm{~W} / \mathrm{m}-{ }^{\circ} \mathrm{C}$, as have analyses of other tanks (McLaren, 1993). With this in mind, a factor of $1.6(2.345 / 1.465=1.6)$ can be applied to the results of the analyses reported in McLaren, 1993. The error band can be considered to be $\pm 38 \%$ until better information becomes available. 
This page intentionally left blank. 


\subsection{REFERENCES}

Caggiano, J. A. and S. M. Goodwin, 1991, Interim Status Groundwater Monitoring Plan for the Single-Shell Tanks, WHC-SD-EN-AP-012, Rev. 1, Westinghouse Hanford Company, Richland, Washington.

Hanlon, B. M., 1991, Tank Farm Surveillance and Waste Status Report for July 1991, WHC-EP-182-40, Westinghouse Hanford Company, Richland, Washington.

Kincaid, C. T., J. W. Shade, G. A. Whyatt, M. G. Piepho, K. Rhodes, J. A. Voogd, J. H. Westsik, M. D. Freshley, K. A. Blanchard, and B. G. Lauzon, 1993, Performance Assessment of Grouted Double-Shell Waste Disposal at Hanford, WHC-SD-WM-EE-004, Rev. 0, Westinghouse Hanford company, Richland, Washington.

McLaren, J. M., 1991, Single-Shell Tank 104-BY Thermal-Hydraulic Analysis, WHC-EP-0591, Rev. 1, Westinghouse Hanford Company, Richland, Washington.

McLaren, J. M., 1993, Ferrocyanide Safety Program: Heat Load and Thermal Characteristics Determination for Selected Tanks, WHC-EP-0638, Rev. 0, Westinghouse Hanford Company, Richland, Washington.

Price, W. H. and K. R. Fecht, 1976, Geology of the 241-C Tank Farm, Informal Report ARH-LD-132, Atlantic Richfield Hanford Company, Richland, Washington. 


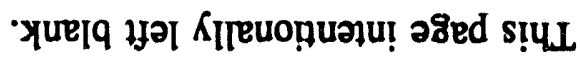


APPENDIX A

METEOROLOGICAL DATA 
This page intentionally left blank. 
Table A-1. Average Dry Bulb Temperature 1912-1975 ( $\left.{ }^{\circ} \mathrm{F}, 4 \mathrm{ft}\right)$.

\begin{tabular}{|c|c|c|}
\hline 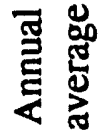 & 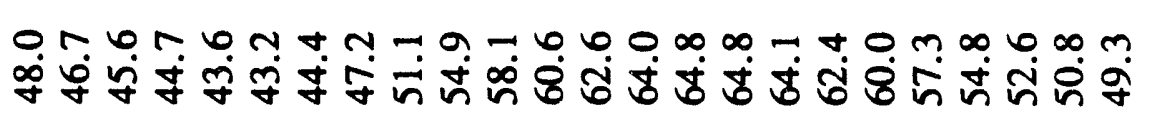 & $\begin{array}{l}0 \\
\dot{f}\end{array}$ \\
\hline §్ & Ọ & $\stackrel{\infty}{m}$ \\
\hline ż & 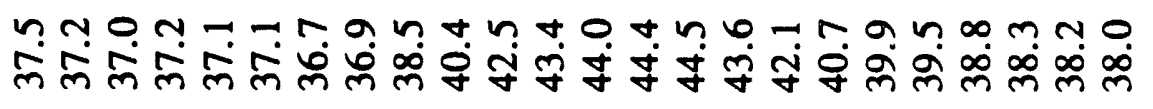 & $\ddot{g}$ \\
\hline $\bar{\delta}$ & 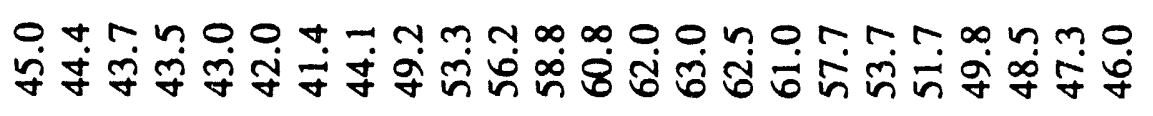 & $\frac{n}{n}$ \\
\hline 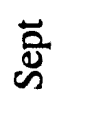 & 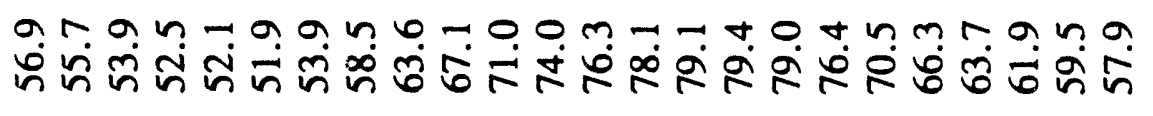 & $\ddot{v}$ \\
\hline$\stackrel{\infty 0}{z}$ & 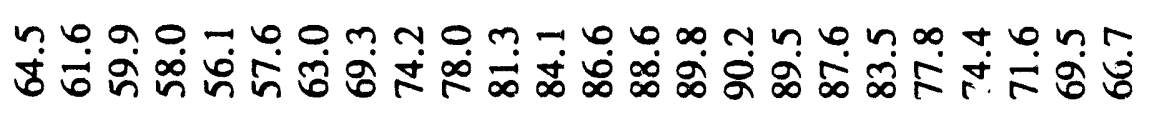 & 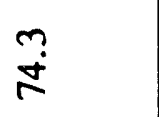 \\
\hline$\underset{\Xi}{\Xi}$ & 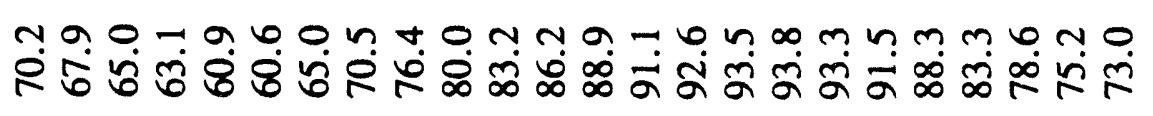 & $\stackrel{\infty}{\infty} \underset{\infty}{\infty}$ \\
\hline$\stackrel{Ð}{\Xi}$ & 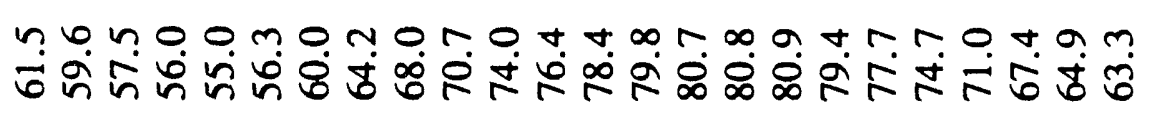 & $\stackrel{0}{g}$ \\
\hline 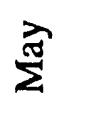 & 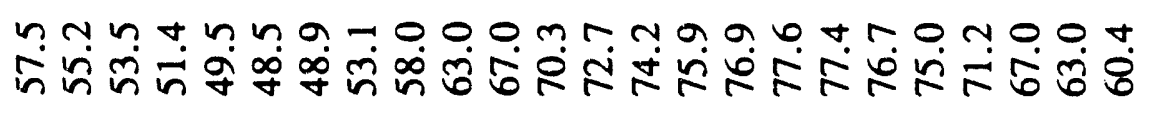 & $\stackrel{m}{\sharp ্}$ \\
\hline 定 & 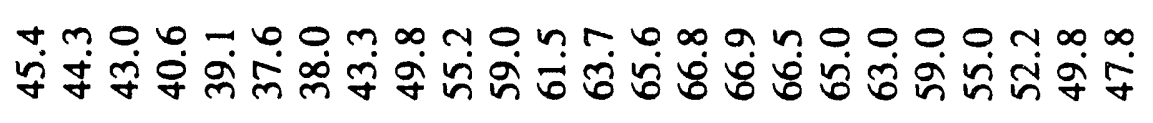 & $\tilde{n}$ \\
\hline 总 & 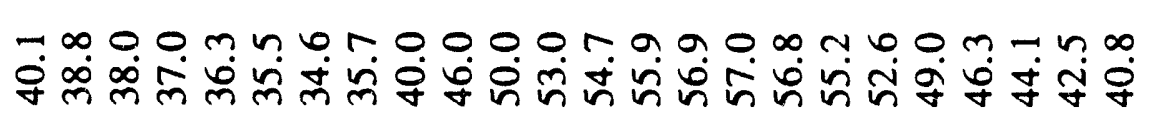 & $\dot{v}$ \\
\hline Q & o & $\underset{\infty}{\infty}$ \\
\hline 疍 & 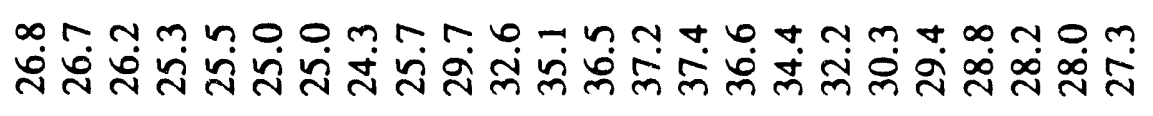 & $\ddot{2}$ \\
\hline 亭 & 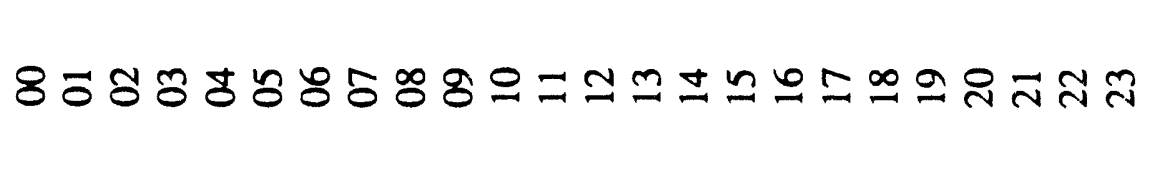 & 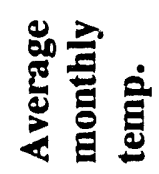 \\
\hline
\end{tabular}




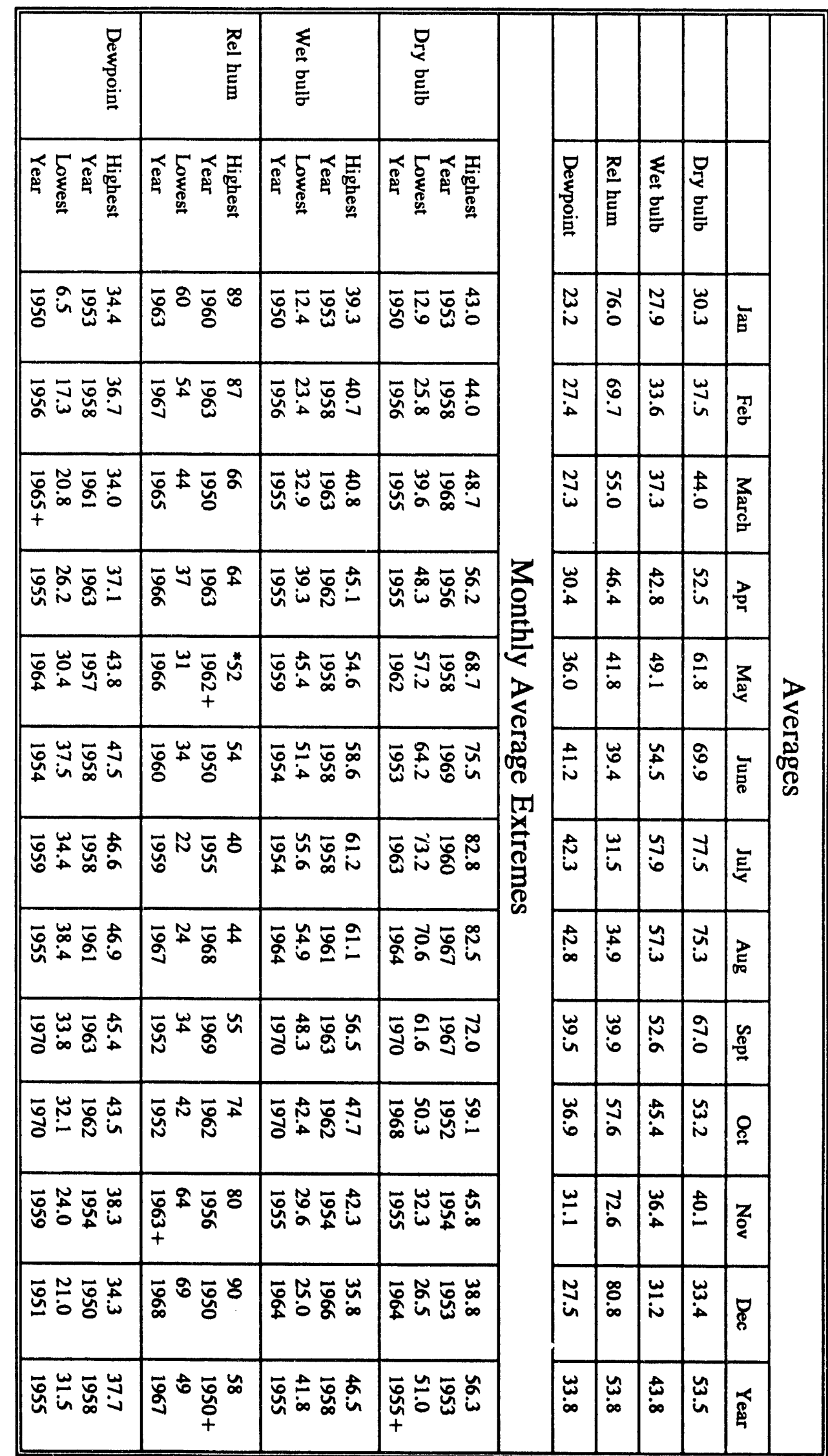


APPENDIX B

THERMAL CONDUCTIVITY OF HANFORD WASTE TANK SOLIDS AND SX TANK FARM SOIL SAMPLES 
This page intentionally left blank. 
THERMAL CONDUCTIVITY OF HANFORD WASTE TANK SOLIDS AND SX TANK FARM SOIL SAMPLES

D. G. Bouse

Chemical Technology Laboratory

Research Department

Research and Engineering Division

July 1975

\section{ATLANTIC RICHFIELD HANFORD COMPANY \\ RICHLAND, WASHINGTON 99352}

Operated for the Energy Research and Development Administration by Atlantic Richfield Hanford Company under Contract AT(45-1)-2130 


\section{THERMAL CONDUCTIVITY OF HANFORD WASTE TANK SOLIDS AND SX TANK FARM SOIL SAMPLES}

\section{INTRODUCTION}

Waste storage tanks in the 200 areas of the Hanford Project have been fabricated with single-thickness carbon steel liners to contain salt cake and supernatant from fuels reprocessing plants during their operating lives. The decay of fission product isotopes dispersed in the saltcake can generate sufficient heat in some tanks to structurally weaken the containment system. Heat is dissipated from the saltcake to the soil surrounding the tanks and through air cooling. One measure of the rate of heat dissipation and centerline temperature is the thermal conductivity (TC) described with results of measurements in this paper.

\section{SUMMARY}

Recent sampling efforts produced solids from 12 Hanford waste tanks in sufficient volume for TC measurements. Thermal conductivity values varied widely with sample composition, physical characteristics, moisture content, measurement temperature, and sample density. Of the above variables, only the temperature was controlled; however, samples were firmly packed in an effort to simulate in situ conditions. Thermal conductivity of Hanford waste tank samples ranged from 0.151 to 1.848 watts $/ \mathrm{meter}^{2} /$ degree celsius/degree celsius/meter or $\mathrm{wm} /{ }^{\circ} \mathrm{C}$. Thermal conductivity of soil samples taken from dry wells around the SX Tank Farm ranged from 0.221 to $2.095 \mathrm{w} / \mathrm{m}^{\circ} \mathrm{C}$.

\section{MEASUREMENT METHOD AND EOUIPMENT}

The method chosen for TC measurement of Hanford waste tank solids was an unsteady state or line source method. In addition to accuracy and its adaptability to remote measurements of highly radioactive waste samples, the method is simple, rapid, and can be performed with inexpensive equipment. With this method, the temperature rise with time of a line source of heat within the sample is a function of the rate of energy input and the heat conducting properties of the sample. Equipment used for the TC measurements consisted of a 30-gauge (10-mil) ni-chrome heater wire and a 30-gauge iron-constant thermocouple fashioned into a single probe which was embedded in the center of the sample. Current to the heater wire was supplied by a Sorensen Power Supply Model WRD 30-1. A small bleed resistor, in the form of a light bulb drawing about 75 milliamperes (ma), was placed across the terminals of the power supply to avoid an unsteady surge of current when starting tile experiment. The current to the heater wire was monitored with a Fluke 8000-A digital multimeter and controlled to $\pm 0.5 \mathrm{ma}$. Initial sample temperature, temperature rise, and 
time were measured with a Hewlett-Packard Model 7101-B strip chart recorder. The recorder, equipped with a Model 17505-A plug-in module, was capable of measuring 0 to 0.1 millivolt (mv) over a 10 -in. span with a response time of one half second full scale. In order to maintain this sensitivity over a wide range of temperatures, a small bucking voltage was applied in the thermocouple circuit. This voltage was supplied by a 1.6 -volt (V) mercury dry cell through a variable wire wound resistor. An ice bath cold junction was also used in the thermocouple circuits as a constant reference temperature.

\section{SAMPLE PREPARATION}

Whenever possible, a sample of about $250 \mathrm{cc}$ packed volume is used for TC measurements. Many sampling efforts produce much smaller volumes of sample and on occasion, volumes of $100 \mathrm{cc}$ packed volume have been used successfully. It is important that the sample volume be large enough that the expanding temperature field does not reach a boundary during the course of the measurement.

The small wire required for the heater and thermocouple made it impractical to force the probe into the sample. It was necessary to place a glass beaker in a glass-col heating mantle (used for measurements at an elevated temperature) center the probe in the beaker, and then add small increments of sample around the probe while tamping the sample surface with a blunt instrument for uniform compaction. Once the sample and probe were in place, it was not practical to measure sample density.

The sample moisture content very likely changed through handling between the time it was removed from the tank and the time the TC measurements were made. Each sample was measured at room temperature in the "as received" condition, at various elevated temperatures, and when completely dry. Both sample density and moisture content were changed by heating.

\section{PROCEDURE}

Once the sample probe is in place, the sample is not disturbed (except by heating) throughout a series of TC measurements.

A baseline temperature is established when no change is observed over a 5-min period. The recorder is set to measure $0.5 \mathrm{mv}$ full scale and a chart speed of $0.1 \mathrm{in}$. per second. A preset current, adjusted to produce a temperature rise within a sample of between 2 and $5^{\circ} \mathrm{F} / \mathrm{min}$, is applied to the heater wire, and the temperature rise with time is recorded for a period of $5 \mathrm{~min}$. The TC of the sample can then be calculated from the time-temperature plot and the known energy input. 


\section{CALCULATION OF THERMAL CONDUCTIVITY FROM THE DATA}

One error inherent in the line-source method is that the heat source is not a mathematical line but has a finite radius and thermal properties different from the material it displaces. There may be some resistance to heat transfer (such as an air film) between the source and the sample. Also included in this error is a portion which results from the temperature measuring point being displaced from the theoretical central line. These have all been shown to be equivalent to a constant error in the time observation. A simple method for determining the value of the time correction was given in the literature. The data points obtained from the temperature rise-time chart are plotted on semi-logarithmic coordinate paper. Uncorrected, the result is a slightly curved line. A straightedge is laid on the plot and adjusted until it lies a constant number of seconds away from each data point. A line drawn along the straightedge represents the temperature rise with corrected time. The rate of heat input to the sample from the line source is determined from the current and the known resistance of the wire per foot of length. The current squared times this resistance is the heat input in watts per foot, which is converted to Btu per hour per foot by multiplying by the factor 3.413. The TC " $k$ " is calculated by the equation:

$$
k=\frac{I^{2} R \times 3.413}{4 \Pi\left(t \theta_{2}-t \theta_{1}\right) \operatorname{cor} I} \times 2.303 \log \frac{\theta_{2} \operatorname{cor} I}{\theta_{1} \operatorname{cor} r}
$$

For convenience, $\Delta t$ is taken from the time correction plot as the temperature rise between 10 and 100 seconds, thus $\frac{\theta_{2} \text { corr }}{\theta_{1} \text { corr }}=10$ and the logarithm of the ratio is unity. The probe, designed for use in waste tank solids, has two heater wires since the wire is looped about 0.75 in. below the thermocouple with both ends terminating in a plug-in block above the sample. Possible objections to the use of two heater wires are overcome in part by the observed time correction as explained earlier. A second possible objection, that of distortion of the cylindrical temperature field resulting from axial flow of heat, is overcome by extending the wire well below the temperature measuring point, in effect increasing the length to diameter ratio. (It has been shown that error from this source vanishes for larger length to diameter ratios.) The loop in the wire is sufficiently below the temperature measuring point so that heat generated at the loop does not enter the measurement field. Tests have shown that a simple factor of 2 accounts for the second heater wire contribution in the calculation. The resistance value used in the calculation is that of the heater wire at the initial temperature of the sample. The slight change in resistance that occurs (over the measurement temperature range) is considered negligible. Grouping constants in equation (1) and using the equipment described, the equation becomes:

$$
k=\frac{I^{2} R \times 1.251}{\Delta t}=B t u / h r f t^{2}\left({ }^{\circ} F / f t\right)
$$


where $\mathrm{I}=$ current applied to the heater wire in amperes

$R=$ resistance of heater wire/foot of length at the sample measurement temperature

$\Delta \mathrm{t}=$ temperature rise as described in the text in ${ }^{\circ} \mathrm{F}$

and $\mathrm{Bt} / \mathrm{hr} \mathrm{ft}{ }^{2}\left({ }^{\circ} \mathrm{F} / \mathrm{ft}\right) \times 1.73=$ watts $/ \mathrm{meter}^{2} /{ }^{\circ} \mathrm{C} / \mathrm{m}=\mathrm{w} / \mathrm{m}{ }^{\circ} \mathrm{C}$.

Samples obtained from Hanford waste tanks are handled through the 222-S, " $1 \mathrm{~A}$ " cell where they are removed from the sampling equipment for various analytical tests and dispensed to the 234-5 Building for TC measurements. Although carefully handled, some moisture is lost from the samples before TC measurements are made. The actual bulk density of the waste tank solids as they exist in the tank is not known precisely and cannot be duplicated exactly when preparing the sample for TC measurement. The above variables each have an effect on the TC and also affect each other; that is the higher the moisture content, the more readily the sample is compacted to a high density. The error resulting from either loss of moisture or inability to compact the material to the extent of the material in situ would be on the low side, thus providing a conservative approximation when using the values to calculate heat transfer within the tank. The TC value, obtained for the dry sample at elevated temneratures, should provide valid data for the worst possible tank conditions, that is if the tank should become completely dry and heat up.

The TC of soil samples taken from dry wells around the SX Tank Farm was measured exactly like the waste tank samples.

Crude bulk density measurements were made on the soil samples by vibrating (dry samples) or compacting (wet samples) the soil in a graduated cylinder and weighing the contents. The 3, 6 and 12 weight percent water was added to soil samples in a plastic bag, sealed, mixed thoroughly, and allowed to stand for at least 16 hours for uniform moisture distribution before measuring the TC.

All TC values shown in Tables B-1, B-3 and B-4 are the average result of at least two determinations at different levels of samples heat input.

Soil sample nomenclature, shown in Table B-2, was taken from ARH-CD-261. 


\begin{tabular}{|c|c|c|c|}
\hline $\begin{array}{c}\text { Tank } \\
\text { Number }\end{array}$ & $\begin{array}{l}\text { T.C. } \\
\mathbf{w} / \mathbf{m}^{\circ} \\
\mathbf{C}\end{array}$ & $\begin{array}{c}\text { Measurement } \\
\text { Temp. }{ }^{\circ} \mathrm{C}\end{array}$ & Conditions \\
\hline $\begin{array}{l}104-S X \\
104-S X \\
104-S X \\
104-S X\end{array}$ & $\begin{array}{l}1.116 \\
1.043 \\
0.585 \\
0.541\end{array}$ & $\begin{array}{l}24.2 \\
115.5 \\
113.5 \\
168.4\end{array}$ & $\begin{array}{l}\text { As received - thick plastic mud, some hard lumps - firmly packed. } \\
\text { Sample molten after standing overnight at } 114^{\circ} \mathrm{C} \text { - Temperature unsteady. } \\
\text { Heat } 40 \text { hours at } 1144^{\circ} \mathrm{C} \text { - Sample dry-hard. } \\
\text { Above sample held over the weekend at temperature shown. }\end{array}$ \\
\hline $\begin{array}{l}108-S \\
108-S \\
108-S \\
108-S \\
108-S \\
\\
108-S \\
108-S \\
108-S\end{array}$ & $\begin{array}{l}0.946 \\
0.900 \\
0.813 \\
0.633 \\
0.567 \\
\\
0.483 \\
0.469 \\
0.471\end{array}$ & $\begin{array}{c}25.2 \\
45.3 \\
67.7 \\
80.2 \\
102.8 \\
\\
104.8 \\
134.6 \\
157.7\end{array}$ & $\begin{array}{l}\text { As received - damp, soft, yellow crystals, some dark surface material. } \\
\text { Above sample held overnight at temperature shown. } \\
\text { Above sample heated to temperature shown. } \\
\text { Above sample held overnight at temperature shown. Liquid on top of sample. } \\
\text { Above sample held } 40 \text { hours at temperature shown. Internal temperature shown unsteady, } \\
\text { molten? } \\
\text { Above sample held over the weekend at temperature shown. } \\
\text { Above sample held overnight at temperature shown. } \\
\text { Above sample held overnight at temperature shown. }\end{array}$ \\
\hline $\begin{array}{l}107-S \\
107-S \\
107-S \\
107-S \\
107-S\end{array}$ & $\begin{array}{l}0.775 \\
0.934 \\
0.317 \\
0.144 \\
0.151 \\
\end{array}$ & $\begin{array}{l}24.9 \\
100.8 \\
135.2 \\
201.0 \\
24.75\end{array}$ & $\begin{array}{l}\text { As received - lumps - dry outside, wet inside - firmly packed. } \\
\text { Above sample held } 40 \text { hours at temperature shown. Sample was liquid at } 80{ }^{\circ} \mathrm{C} \text {. } \\
\text { Above sample liquified at } 109^{\circ} \mathrm{C} \text {. Held } 22 \text { hours at } 135^{\circ} \mathrm{C} \text {. Sample was dry soft } \\
\text { powder. Repacked to }-80 \% \text { of original volume. } \\
\text { Above sample held overnight at temperature shown. } \\
\text { Above sample cooled - left standing open over the weekend. }\end{array}$ \\
\hline $\begin{array}{l}105-S \\
105-S \\
105-S \\
105-S \\
105-S\end{array}$ & $\begin{array}{l}0.434 \\
0.427 \\
0.407 \\
0.374 \\
0.355\end{array}$ & $\begin{array}{l}21.8 \\
62.1 \\
80.0 \\
114.9 \\
156.0\end{array}$ & $\begin{array}{l}\text { As received - fairly dry crystals - firmly packed. } \\
\text { Above sample held overnight at temperature shown. } \\
\text { Above sample held overnight at temperature shown. } \\
\text { Above sample held overnight at temperature shown. } \\
\text { Above sample held over the weekend at temperature shown. }\end{array}$ \\
\hline
\end{tabular}




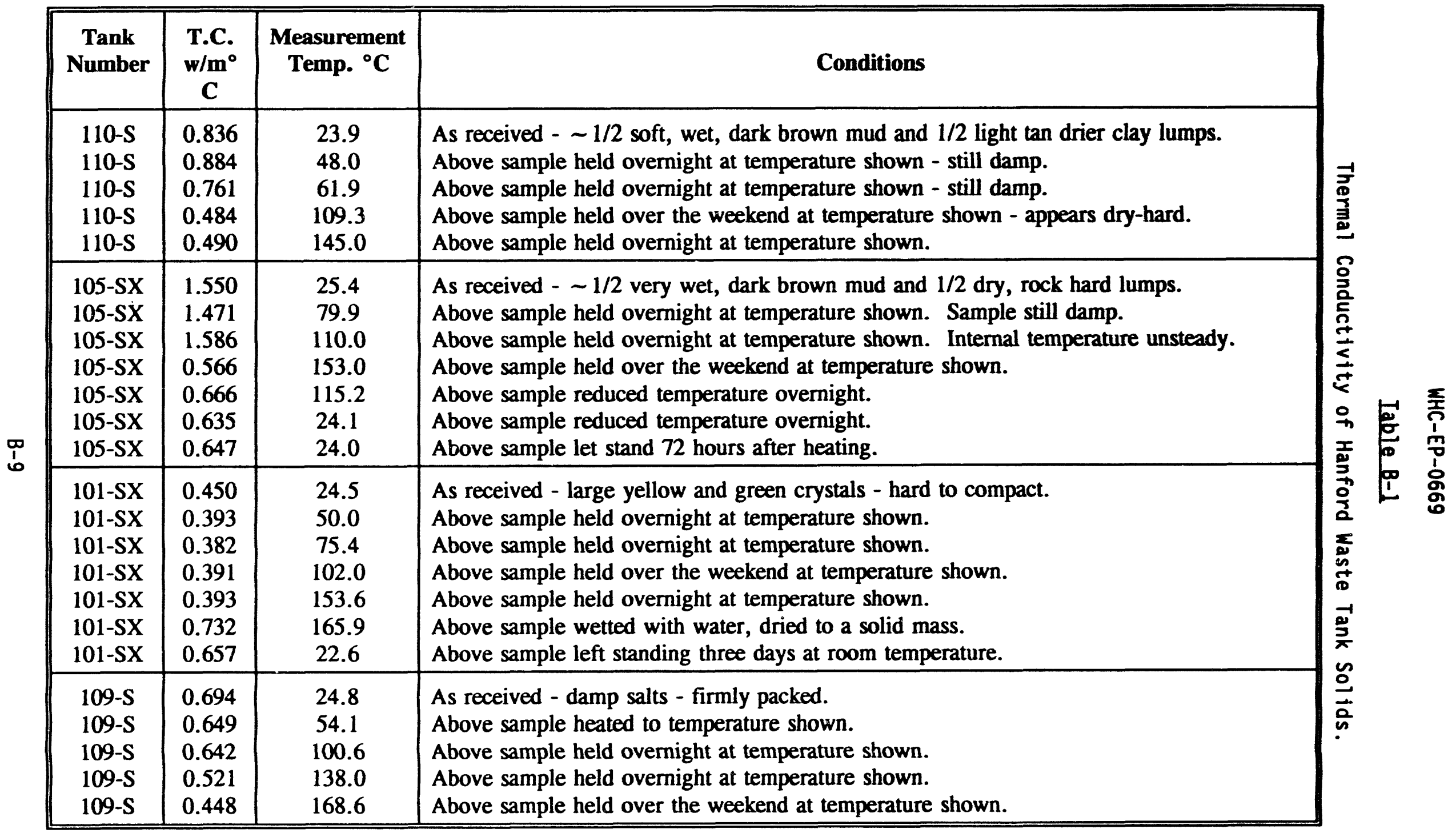




\begin{tabular}{|c|c|c|c|}
\hline $\begin{array}{c}\text { Tank } \\
\text { Number }\end{array}$ & $\begin{array}{c}\text { T.C. } \\
\mathbf{w} / \mathbf{m}^{\circ} \\
\mathbf{C} \\
\end{array}$ & $\begin{array}{l}\text { Measurement } \\
\text { Temp. }{ }^{\circ} \mathbf{C}\end{array}$ & Conditions \\
\hline $\begin{array}{l}106-S \\
106-S \\
106-S \\
106-S\end{array}$ & $\begin{array}{l}1.093 \\
0.947 \\
0.680 \\
0.476\end{array}$ & $\begin{array}{l}22.9 \\
53.1 \\
104.0 \\
161.1\end{array}$ & $\begin{array}{l}\text { As received - soft, wet, yellow salts - firmly packed. } \\
\text { Above sample held overnight at temperature shown. } \\
\text { Above sample partially liquid @ } 90^{\circ} \mathrm{C} \text { - held over the weekend. } \\
\text { Above sample held } 48 \text { hours at temperature shown. }\end{array}$ \\
\hline $\begin{array}{l}102-\mathrm{SX} \\
102-\mathrm{SX} \\
102-\mathrm{SX} \\
102-\mathrm{SX}\end{array}$ & $\begin{array}{c}1.8481 \\
.650 \\
1.353 \\
0.964 \\
\end{array}$ & $\begin{array}{r}23.1 \\
68.4 \\
103.9 \\
164.9\end{array}$ & $\begin{array}{l}\text { As received - gray-brown, sandy, some hard lumps, damp - firmly packed. } \\
\text { Above sample held } 48 \text { hours at temperature shown. } \\
\text { Above sample held over the weekend at temperature shown. } \\
\text { Above sample held overnight at temperature shown. }\end{array}$ \\
\hline $\begin{array}{l}112-S \\
112-S \\
112-S \\
112-S\end{array}$ & $\begin{array}{l}0.706 \\
0.637 \\
0.528 \\
0.426 \\
\end{array}$ & $\begin{array}{l}23.4 \\
60.1 \\
100.3 \\
137.7\end{array}$ & $\begin{array}{l}\text { As received - dirty yellow, damp crystals - firmly packed. } \\
\text { Above sample held overnight at temperature shown. } \\
\text { Above sample held overnight at temperature shown. } \\
\text { Above sample held over the weekend at temperature shown. }\end{array}$ \\
\hline $\begin{array}{l}107-U \\
107-U \\
107-U \\
107-U\end{array}$ & $\begin{array}{l}0.507 \\
0.642 \\
0.301 \\
0.343\end{array}$ & $\begin{array}{l}21.7 \\
58.8 \\
122.1 \\
170.9\end{array}$ & $\begin{array}{l}\text { As received - sample had the appearance of damp coffee grounds. } \\
\text { Above sample dried to a white flecked granular solid - internal temperature unsteady. } \\
\text { Above sample } \sim 50 \% \text { volume shrinkage - soft powdery solid. } \\
\text { Above sample held overnight at temperature shown. }\end{array}$ \\
\hline
\end{tabular}


Table B-2. Grain Size Nomenclature for Hanford Sediments. (Slightly Modified after R. L. Folk)

\begin{tabular}{|c|c|c|}
\hline 1. Gravel & G & $>80 \%$ gravel \\
\hline 2. Sandy Gravel & SG & $\begin{array}{l}30 \% \text { to } 80 \% \text { gravel } \\
<1: 0 \mathrm{M}: S \text { ratio }\end{array}$ \\
\hline 3. Muddy sandy gravei & MSG & $\begin{array}{l}30 \% \text { to } 80 \% \text { gravel } \\
<1: 1 \text { to } 1: 0 \mathrm{M}: \mathrm{S} \text { ratio }\end{array}$ \\
\hline 4. MLidy gravel & MG & $\begin{array}{l}30 \% \text { to } 80 \% \text { gravel } \\
>1: 1 \mathrm{M}: \mathrm{S} \text { ratio }\end{array}$ \\
\hline 5. Sand & $\mathbf{S}$ & $\begin{array}{l}<5 \% \text { gravel } \\
<1: 0 \mathrm{M}: S \text { ratio }\end{array}$ \\
\hline 6. Slightly muddy sand & (M) $\mathrm{S}$ & $\begin{array}{l}<5 \% \text { gravel } \\
1: 9 \text { to }<1: 4 \mathrm{M}: S \text { ratio }\end{array}$ \\
\hline 7. Muddy sand & MS & $\begin{array}{l}<5 \% \text { gravel } \\
1: 4 \text { to }<1: 1 \mathrm{M}: \mathrm{S} \text { ratio }\end{array}$ \\
\hline 8. Slightly gravelly sand & (G) $S$ & $\begin{array}{l}5 \% \text { to }<10 \% \text { gravel } \\
<1: 9 \mathrm{M}: \mathrm{S} \text { ratio }\end{array}$ \\
\hline 9. Slightly gravelly & $(\mathrm{GM}) \mathrm{S}$ & $\begin{array}{l}5 \% \text { to }<10 \% \text { gravel } \\
1: 9 \text { to }<1: 4 \mathrm{M}: S \text { rati }\end{array}$ \\
\hline 10. Slightly gravelly muddy sand & (G) MS & $\begin{array}{l}5 \% \text { to } 10 \% \text { gravel } \\
1: 4 \text { to }<1: 1 \mathrm{M}: \mathrm{S} \text { ratio }\end{array}$ \\
\hline 11. Gravelly Sand & GS & $\begin{array}{l}10 \% \text { to }<30 \% \text { gravel } \\
<1: 9 \mathrm{M}: \mathrm{S} \text { ratio }\end{array}$ \\
\hline 12. Slightly muddy & (M) GS & $\begin{array}{l}10 \% \text { to }<30 \% \text { gravel } \\
1: 0 \text { to }<1: 4 \mathrm{M}: S \text { ratio }\end{array}$ \\
\hline 13. Gravelly muddy sand & GMS & $\begin{array}{l}10 \% \text { to }<30 \% \text { gravel } \\
1: 4 \text { to }<1: 1 \mathrm{M}: \mathrm{S} \text { ratio }\end{array}$ \\
\hline 14. Mud & M & $\begin{array}{l}<5 \% \text { gravel } \\
4: 1 \mathrm{M}: S \text { ratio } \\
\end{array}$ \\
\hline 15. Sandy mud & SM & $\begin{array}{l}<5 \% \text { gravel } \\
1: 1 \text { to }<4: 1 \mathrm{M}: S \text { ratio }\end{array}$ \\
\hline 16. Slightly gravelly mud & (G) $M$ & $\begin{array}{l}5 \% \text { to }<10 \% \text { gravel } \\
4: 1 \mathrm{M}: \mathrm{S} \text { ratio }\end{array}$ \\
\hline 17. Slightly gravelly sand mud & (G) SM & $\begin{array}{l}5 \% \text { to }<10 \% \text { gravel } \\
4: 1 \mathrm{M}: \mathrm{S} \text { ratio }\end{array}$ \\
\hline
\end{tabular}


Table B-2. Grain Size Nomenclature for Hanford Sediments. (Slightly Modified after R. L. Folk)

\begin{tabular}{|l|c|l|}
\hline 18. Gravelly mud & GM & $\begin{array}{l}10 \% \text { to }<30 \% \text { gravel } \\
4: 1 \mathrm{M}: \mathrm{S} \text { ratio }\end{array}$ \\
\hline 19. Gravelly sandy mud & GSM & $\begin{array}{l}10 \% \text { to }<30 \% \text { gravel } \\
1: 1 \text { to }<4: 1 \mathrm{M}: \mathrm{S} \text { ratio }\end{array}$ \\
\hline
\end{tabular}




\begin{tabular}{|c|c|c|c|c|c|}
\hline $\begin{array}{l}\text { Sample } \\
\text { Number }\end{array}$ & $\begin{array}{l}\text { T.C. } \\
\mathbf{w} / \mathbf{m}^{\circ} \\
\mathbf{C}\end{array}$ & $\begin{array}{l}\text { Measurement } \\
\text { Temp. }{ }^{\circ} \mathrm{C}\end{array}$ & $\begin{array}{l}\text { Approximate } \\
\text { Density gm/cc }\end{array}$ & Conditions & \multirow{6}{*}{ 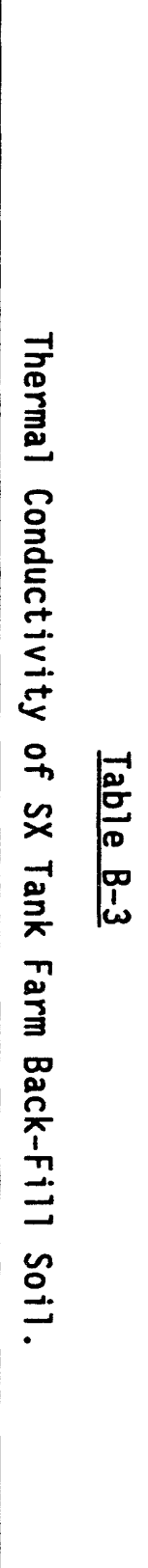 } \\
\hline $\begin{array}{l}\text { SX-S } \\
\text { SX-S } \\
\text { SX-S } \\
\text { SX-S } \\
\text { SX-S }\end{array}$ & $\begin{array}{l}0.279 \\
0.344 \\
0.358 \\
0.355 \\
0.379\end{array}$ & $\begin{array}{c}24.5 \\
24.2 \\
24.4 \\
103.3 \\
148.5\end{array}$ & $\begin{array}{l}1.338 \\
1.580 \\
1.487 \\
1.587 \\
1.587\end{array}$ & $\begin{array}{l}\text { As received - loosely poured - dry. } \\
\text { Above sample vibrated for } 60 \text { seconds. } \\
\text { Above sample vibrated for } 120 \text { seconds. } \\
\text { Above sample held overnight at temperature shown. } \\
\text { Above sample held overnight at temperature shown. }\end{array}$ & \\
\hline $\begin{array}{l}\text { SX-(M)S } \\
\text { SX-(M)S } \\
\text { SX-(M)S } \\
\text { SX-(M)S } \\
\text { SX-(M)S }\end{array}$ & $\begin{array}{l}0.306 \\
0.368 \\
0.377 \\
0.339 \\
0.351\end{array}$ & $\begin{array}{l}24.1 \\
24.0 \\
23.9 \\
100.4 \\
145.3\end{array}$ & $\begin{array}{l}1.352 \\
1.558 \\
1.579 \\
1.579 \\
1.579\end{array}$ & $\begin{array}{l}\text { As received - loosely poured - dry. } \\
\text { Above sample vibrated for } 60 \text { seconds. } \\
\text { Above sample vibrated for } 120 \text { seconds. } \\
\text { Above sample held overnight at temperature shown. } \\
\text { Above sample held overnight at temperature shown. }\end{array}$ & \\
\hline $\begin{array}{l}\text { SX-GS } \\
\text { SX-GS } \\
\text { SX-GS } \\
\text { SX-GS } \\
\text { SX-GS }\end{array}$ & $\begin{array}{l}0.375 \\
0.491 \\
0.503 \\
0.538 \\
0.495\end{array}$ & $\begin{array}{l}24.1 \\
24.1 \\
23.5 \\
108.0 \\
147.4\end{array}$ & $\begin{array}{l}1.684 \\
1.871 \\
1.913 \\
1.913 \\
1.913\end{array}$ & $\begin{array}{l}\text { As received - loosely poured - dry. } \\
\text { Above sample vibrated for } 60 \text { seconds. } \\
\text { Above sample vibrated for } 120 \text { seconds. } \\
\text { Above sample held overnight at temperature shown. } \\
\text { Above sample held overnight at temperature shown. }\end{array}$ & \\
\hline $\begin{array}{l}\text { SX-SM } \\
\text { SX-SM } \\
\text { SX-SM } \\
\text { SX-SM } \\
\text { SX-SM }\end{array}$ & $\begin{array}{l}0.221 \\
0.322 \\
0.327 \\
0.479 \\
0.310\end{array}$ & $\begin{array}{l}26.1 \\
26.1 \\
26.3 \\
144.0 \\
155.0\end{array}$ & $\begin{array}{l}1.289 \\
1.517 \\
1.558 \\
1.558 \\
1.558\end{array}$ & $\begin{array}{l}\text { As received - loosely poured - dry. } \\
\text { Above sample vibrated for } 60 \text { seconds. } \\
\text { Above sample vibrated for } 120 \text { seconds. } \\
\text { Above sample held overnight at temperature shown. } \\
\text { Above sample held overnight at temperature shown. }\end{array}$ & \\
\hline $\begin{array}{l}\text { SX- } \\
\text { (G)MS } \\
\text { SX- } \\
\text { (G)MS } \\
\text { SX- } \\
\text { (G)MS } \\
\text { SX- } \\
\text { (G)MS }\end{array}$ & $\begin{array}{l}0.298 \\
0.420 \\
0.433 \\
0.450\end{array}$ & $\begin{array}{l}25.0 \\
25.0 \\
101.7 \\
151.9\end{array}$ & $\begin{array}{l}1.504 \\
1.790 \\
1.790 \\
1.790\end{array}$ & $\begin{array}{l}\text { As received - loosely poured - dry. } \\
\text { Above sample vibrated for } 120 \text { seconds. } \\
\text { Above sample held overnight at temperature shown. } \\
\text { Above sample held overnight at temperature shown. }\end{array}$ & \\
\hline
\end{tabular}




\begin{tabular}{|c|c|c|c|c|}
\hline $\begin{array}{l}\text { Sample } \\
\text { Number }\end{array}$ & $\begin{array}{l}\text { T.C. } \\
\mathbf{w} / \mathbf{m}^{\circ} \\
\mathbf{C}\end{array}$ & $\begin{array}{l}\text { Measurement } \\
\text { Temp. }{ }^{\circ} \mathbf{C}\end{array}$ & $\begin{array}{l}\text { Approximate } \\
\text { Density gm/cc }\end{array}$ & Conditions \\
\hline $\begin{array}{l}\text { SX-SG } \\
\text { SX-SG } \\
\text { SX-SG } \\
\text { SX-SG }\end{array}$ & $\begin{array}{l}0.611 \\
0.782 \\
0.886 \\
0.836\end{array}$ & $\begin{array}{r}24.0 \\
23.7 \\
102.0 \\
150.6\end{array}$ & $\begin{array}{l}1.756 \\
2.076 \\
2.076 \\
2.076\end{array}$ & $\begin{array}{l}\text { As received - loosely poured - dry. } \\
\text { Above sample vibrated for } 120 \text { seconds. } \\
\text { Above sample held overnight at temperature shown. } \\
\text { Above sample held overnight at temperature shown. }\end{array}$ \\
\hline $\begin{array}{c}\text { SX- } \\
\text { (M)GS } \\
\text { SX- } \\
\text { (M)GS } \\
\text { SX- } \\
\text { (M)GS } \\
\text { SX- } \\
\text { (M)GS }\end{array}$ & $\begin{array}{l}0.388 \\
0.682 \\
0.702 \\
0.676\end{array}$ & $\begin{array}{c}24.1 \\
24.7 \\
103.9 \\
71.5\end{array}$ & $\begin{array}{l}1.660 \\
1.921 \\
1.921 \\
1.921\end{array}$ & $\begin{array}{l}\text { As received - loosely poured - dry. } \\
\text { Above sample vibrated for } 120 \text { seconds. } \\
\text { Above sample held overnight at temperature shown. } \\
\text { Above sample cooled overnight to temperature shown. }\end{array}$ \\
\hline $\begin{array}{l}\text { SX-GMS } \\
\text { SX-GMS } \\
\text { SX-GMS } \\
\text { SX-GMS }\end{array}$ & $\begin{array}{l}0.346 \\
0.545 \\
0.529 \\
0.524\end{array}$ & $\begin{array}{c}24.1 \\
24.4 \\
57.4 \\
101.7 \\
\end{array}$ & $\begin{array}{l}1.611 \\
1.900 \\
1.900 \\
1.900 \\
\end{array}$ & $\begin{array}{l}\text { As received - loosely poured - dry. } \\
\text { Above sample vibrated for } 120 \text { seconds. } \\
\text { Above sample held overnight at temperature shown. } \\
\text { Above sample held overnight at temperature shown. }\end{array}$ \\
\hline $\begin{array}{l}\text { SX-(G)S } \\
\text { SX-(G)S } \\
\text { SX-(G)S } \\
\text { SX-(G)S }\end{array}$ & $\begin{array}{l}0.344 \\
0.495 \\
0.517 \\
0.481\end{array}$ & $\begin{array}{c}24.2 \\
22.2 \\
64.2 \\
109.7\end{array}$ & $\begin{array}{l}1.650 \\
1.887 \\
1.887 \\
1.887\end{array}$ & $\begin{array}{l}\text { As received - loosely poured - dry. } \\
\text { Above sample vibrated for } 120 \text { seconds. } \\
\text { Above sample held overnight at temperature shown. } \\
\text { Above sample held overnight at temperature shown. }\end{array}$ \\
\hline $\begin{array}{l}\text { SX-MSG } \\
\text { SX-MSG } \\
\text { SX-MSG } \\
\text { SX-MSG }\end{array}$ & $\begin{array}{l}0.394 \\
0.588 \\
0.590 \\
0.574\end{array}$ & $\begin{array}{c}24.9 \\
25.4 \\
69.2 \\
108.8\end{array}$ & $\begin{array}{l}1.811 \\
2.136 \\
2.136 \\
2.136\end{array}$ & $\begin{array}{l}\text { As received - loosely poured - dry. } \\
\text { Above sample vibrated for } 120 \text { seconds. } \\
\text { Above sample held overnight at temperature shown. } \\
\text { Above sample held overnight at temperature shown. }\end{array}$ \\
\hline
\end{tabular}




\begin{tabular}{|c|c|c|c|c|}
\hline $\begin{array}{l}\text { Sample } \\
\text { Number }\end{array}$ & $\begin{array}{l}\text { T.C. } \\
\mathbf{w} / \mathbf{m}^{\circ} \\
\mathbf{C}\end{array}$ & $\begin{array}{l}\text { Measurement } \\
\text { Temp. }{ }^{\circ} \mathrm{C}\end{array}$ & $\begin{array}{l}\text { Approximate } \\
\text { Density gm/cc }\end{array}$ & Conditions \\
\hline $\begin{array}{l}\text { SX-MS } \\
\text { SX-MS } \\
\text { SX-MS } \\
\text { SX-MS }\end{array}$ & $\begin{array}{l}0.251 \\
0.360 \\
0.353 \\
0.365\end{array}$ & $\begin{array}{r}24.1 \\
24.5 \\
67.7 \\
115.8 \\
\end{array}$ & $\begin{array}{l}1.316 \\
1.613 \\
1.613 \\
1.613 \\
\end{array}$ & $\begin{array}{l}\text { As received - loosely poured - dry. } \\
\text { Above sample vibrated for } 120 \text { seconds. } \\
\text { Above sample held overnight at temperature shown. } \\
\text { Above sample held overnight at temperature shown. }\end{array}$ \\
\hline $\begin{array}{l}S X-(M) S \\
S X-(M) S \\
S X-(M) S\end{array}$ & $\begin{array}{l}0.353 \\
0.358 \\
0.368 \\
\end{array}$ & $\begin{array}{l}23.1 \\
106.0 \\
179.6\end{array}$ & $\begin{array}{l}1.6466 \\
1.6466 \\
1.6466 \\
\end{array}$ & $\begin{array}{l}\text { As received - dry - vibrated for } 180 \text { seconds. } \\
\text { Above sample held overnight at temperature shown. } \\
\text { Above sample held overnight at temperature shown. }\end{array}$ \\
\hline $\begin{array}{c}\text { SX- } \\
(\mathrm{GM}) \mathrm{S} \\
\text { SX- } \\
(\mathrm{GM}) \mathrm{S} \\
\text { SX- } \\
(\mathrm{GM}) \mathrm{S}\end{array}$ & $\begin{array}{l}0.375 \\
0.367 \\
0.365\end{array}$ & $\begin{array}{l}23.2 \\
73.5 \\
156.7\end{array}$ & $\begin{array}{l}1.798 \\
1.798 \\
1.798\end{array}$ & $\begin{array}{l}\text { As received - dry - vibrated for } 180 \text { seconds. } \\
\text { Above sample held overnight at temperature shown. } \\
\text { Above sample held overnight at temperature shown. }\end{array}$ \\
\hline
\end{tabular}

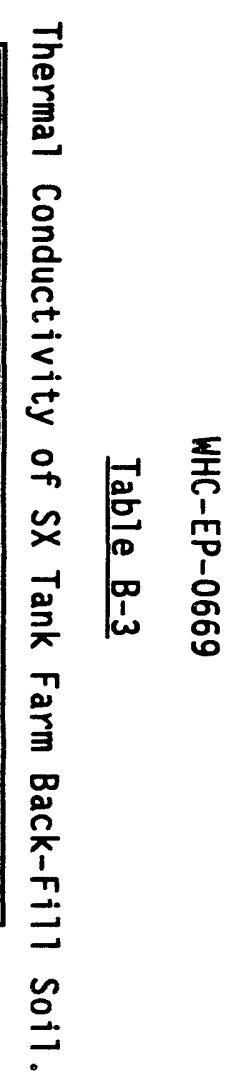


Table B-4. Thermal Conductivity Measurements -

Hanford Tank Farm Back-Fill Soil Samples.

\begin{tabular}{|c|c|c|c|c|}
\hline $\begin{array}{l}\text { Sample } \\
\text { Number }\end{array}$ & $\begin{array}{c}\mathrm{TC} \\
\mathrm{w} / \mathrm{m}^{\circ} \mathrm{C}\end{array}$ & $\begin{array}{l}\text { Measurement } \\
\text { Temp. }{ }^{\circ} \mathrm{C}\end{array}$ & $\begin{array}{c}\text { Water Added } \\
\text { Weight \% }\end{array}$ & $\begin{array}{c}\text { Approximate } \\
\text { Density GM/CC }\end{array}$ \\
\hline $\begin{array}{l}\text { SX-MS } \\
\text { SX-MS } \\
\text { SX-MS } \\
\text { SX-MS }\end{array}$ & $\begin{array}{l}0.453 \\
0.313 \\
0.320 \\
0.318\end{array}$ & $\begin{array}{c}21.9 \\
68.1 \\
89.6 \\
152.1\end{array}$ & $\begin{array}{c}3 \\
\cdots \\
\cdots \\
\cdots-\end{array}$ & $\begin{array}{l}1.57 \\
-\cdots \\
-- \\
---\end{array}$ \\
\hline $\begin{array}{l}\text { SX-S } \\
\text { SX-S } \\
\text { SX-S } \\
\text { SX-S }\end{array}$ & $\begin{array}{l}0.381 \\
0.301 \\
0.303 \\
0.322\end{array}$ & $\begin{array}{c}22.0 \\
71.4 \\
93.3 \\
149.3\end{array}$ & $\begin{array}{l}3 \\
--- \\
-- \\
--\end{array}$ & $\begin{array}{c}1.47 \\
-- \\
-- \\
---\end{array}$ \\
\hline $\begin{array}{l}\text { SX-(M) GS } \\
\text { SX-(M) GS } \\
\text { SX-(M) GS } \\
\text { SX-(M) GS }\end{array}$ & $\begin{array}{l}0.533 \\
0.394 \\
0.400 \\
0.415\end{array}$ & $\begin{array}{c}21.3 \\
72.3 \\
100.7 \\
159.7\end{array}$ & $\begin{array}{c}3 \\
--- \\
-- \\
--\end{array}$ & $\begin{array}{c}1.73 \\
-\cdots \\
--. \\
--\end{array}$ \\
\hline $\begin{array}{l}\text { SX-MS } \\
\text { SX-MS } \\
\text { SX-MS } \\
\text { SX-MS }\end{array}$ & $\begin{array}{l}1.022 \\
0.349 \\
0.330 \\
0.327\end{array}$ & $\begin{array}{c}23.4 \\
70.5 \\
101.4 \\
154.7\end{array}$ & $\begin{array}{c}6 \\
\cdots \\
\cdots- \\
\cdots\end{array}$ & $\begin{array}{l}1.62 \\
-\cdots \\
--- \\
---\end{array}$ \\
\hline $\begin{array}{l}\text { SX-S } \\
\text { SX-S } \\
\text { SX-S } \\
\text { SX-S }\end{array}$ & $\begin{array}{l}1.225 \\
0.422 \\
0.413 \\
0.446\end{array}$ & $\begin{array}{c}22.6 \\
75.2 \\
101.2 \\
156.9\end{array}$ & $\begin{array}{c}6 \\
\cdots \\
\cdots \\
\cdots\end{array}$ & $\begin{array}{l}1.57 \\
-\cdots \\
--- \\
---\end{array}$ \\
\hline $\begin{array}{l}\text { SX-(M) GS } \\
\text { SX-(M) GS } \\
\text { SX-(M) GS } \\
\text { SX-(M) GS }\end{array}$ & $\begin{array}{l}1.310 \\
0.659 \\
0.559 \\
0.536\end{array}$ & $\begin{array}{c}22.9 \\
61.2 \\
102.6 \\
152.1\end{array}$ & $\begin{array}{c}6 \\
\cdots-- \\
\cdots-\end{array}$ & $\begin{array}{l}1.92 \\
-\cdots \\
-- \\
-\cdots\end{array}$ \\
\hline $\begin{array}{l}\text { SX-MS } \\
\text { SX-MS } \\
\text { SX-MS } \\
\text { SX-MS }\end{array}$ & $\begin{array}{l}1.358 \\
0.804 \\
0.519 \\
0.493\end{array}$ & $\begin{array}{c}23.5 \\
60.4 \\
111.3 \\
151.5\end{array}$ & $\begin{array}{l}12 \\
-- \\
-- \\
--\end{array}$ & $\begin{array}{l}1.76 \\
--- \\
--- \\
---\end{array}$ \\
\hline $\begin{array}{r}\text { SX-S } \\
\text { * SX-S } \\
\text { * SX-S } \\
\text { SX-S } \\
\text { SX-S }\end{array}$ & $\begin{array}{l}1.695 \\
1.368 \\
0.867 \\
0.538 \\
0.547\end{array}$ & $\begin{array}{c}23.9 \\
61.9 \\
61.9 \\
94.4 \\
149.8\end{array}$ & $\begin{array}{l}12 \\
-- \\
\cdots- \\
---\end{array}$ & $\begin{array}{c}1.71 \\
--- \\
--- \\
--- \\
---\end{array}$ \\
\hline
\end{tabular}


Table B-4. Thermal Conductivity Measurements -

Hanford Tank Farm Back-Fill Soil Samples.

\begin{tabular}{||c|c|c|c|c||}
\hline $\begin{array}{c}\text { Sample } \\
\text { Number }\end{array}$ & $\begin{array}{c}\text { TC } \\
\text { w/m }\end{array}{ }^{\circ} \mathrm{C}$ & $\begin{array}{c}\text { Measurement } \\
\text { Temp. }{ }^{\circ} \mathrm{C}\end{array}$ & $\begin{array}{c}\text { Water Added } \\
\text { Weight \% }\end{array}$ & $\begin{array}{c}\text { Approximate } \\
\text { Density GM/CC }\end{array}$ \\
\hline SX-(M) GS & 1.310 & 22.9 & 12 & 2.20 \\
SX-(M) GS & 0.659 & 61.2 & --- & --- \\
SX-(M) GS & 0.559 & 102.6 & --- & --- \\
SX-(M) GS & 0.536 & 152.1 & -- & - \\
\hline
\end{tabular}

* Three hours elapsed between measurements. Sample was still drying.

** This sample was saturated at 12 weight percent water. 
This page intentionally left blank. 


\section{DISTRIBUTION}

\section{Number of Copies}

\section{OFFSITE}

12

U.S. Department of Energy

EM-35, Trevion II

Washington, D.C. 20585

John C. Tseng

1

U.S. Department of Energy

Savannah River Operations Office

P.O. Box A

Aiken, South Carolina 29808

Thomas C. Temple

1

Charles S. Abrams

1987 Virginia

Idaho Falls, ID 83404

1

David O. Campbell

102 Windham Road

Oak Ridge, TN 37830

1 Fred N. Carlson

6965 North 5th West

Idaho Falls, ID 83401

1 Donald T. Oakley

409 12th Street SW, Suite 310

Washington, DC 20024-2188

1

Arlin K. Postma

3640 Ballard Road

Dallis, Oregon 97338

1

William R. Prindle 1556 Crestline Drive

Santa Barbara, CA 93105 


\section{DISTRIBUTION (Continued)}

\section{Number of Copies}

\section{OFFSITE}

Alfred Schneider

5005 Hidden Branches Drive

Dunwoody, GA 30338

Air Products \& Chemicals, Inc. 7201 Hamilton Blvd Allentown, PA 18195-1501

George E. Schmauch

1

Battelle Columbus Laboratories 505 King Avenue

Columbus, OH 43201-2693

James A. Gieseke

1

Brookhaven National Laboratory

Upton, NY 11973

Kamal K. Bandyopadhyay

1

Design Science, Inc. 163 Witherow Road

Sewickley, PA 15143

Gary Powers

1

Fauske and Associates, Inc. 16W070 W. 83rd St.

Burr Ridge, IL 60521

Hans K. Fauske

1

Florida State University

Department of Chemistry B-164

Tallahassee, FL 32306

Greg R. Choppin 


\section{DISTRIBUTION (Continued)}

Number of Copies

\section{OFFSITE}

1

Harvard University

295 Upland Avenue

Newton Highlands, MA 02161

Melvin W. First

1

Hazards Research Corporation

200 Valley Road, Suite 301

Mt. Arlington, NJ 07856

Chester Grelecki

1

Lawrence Livermore National Laboratory

P.O. Box 808, L-221

Livermore, CA 94550

Billy C. Hudson

4

Los Alamos National Laboratory

P.O. Box 1663

Los Alamos, NM 87545

Steve F. Agnew

Steve W. Eisenhawer

Thomas E. Larson

L. Harold Sullivan

$1 \quad$ MIT/Department of Nuclear Engineering

77 Massachusetts Ave.

Room 24-102

Cambridge, MA 02139

Mujid S. Kazimi 
DISTRIBUTION (Continued)

\section{Number of Copies}

\section{QFFSITE}

Nuclear Consulting Services. Inc.

P.O. Box 29151

Columbus, $\mathrm{OH} 43229$

J. Louis Kovach

Oak Ridge National Laboratory

Emory D. Collins

P.O. Box 2008

7930, MS-6385

Oak Ridge, TN 37831-6385

Charles W. Forsberg

P.O. Box 2008

MS-6495

Oak Ridge, TN 37831-6495

Thomas S. Kress

P.O. Box 2009

9108, MS-8088

Oak Ridge, TN 37831-8088

1

Rice University

5211 Paisley

Houston, TX 77096

Andrew S. Veletsos

1

Sandia National Laboratory

P.O. Box 5800

Albuquerque, NM 87185

Scott E. Slezak 


\section{DISTRIBUTION (Continued)}

\section{Number of Copies}

\section{OFFSITE}

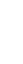

1

1

1
Science Applications International Corporation

12850 Middlebrook Road

Trevion I, Suite 300

Germantown, MD 20874

Attn: Ray S. Daniels (3)

State of Washington

Department of Ecology

P.O. Box 47600

Olympia, WA $98504-7600$

Michael T. Gordon

University of South Carolina

Department of Electrical and Computer Engineering

Swearingen Engineering Center

Columbia, SC 29208

Joseph S. Byrd

University of Washington

Center for Process Analytical Chemistry

Chemistry Department BG-10

Seattle, WA 98195

Bruce R. Kowalski

Vanderbilt University

P.O. Box 1596, Station B

Nashville, TN 37235

Frank L. Parker 
DISTRIBUTION (Continued)

\section{ONSITE}

9

U.S. Department of Energy. Richland Operations Office

R. F. Christensen (4)

R3-72

R. E. Gerton

R3-72

A. G. Krasopoulos

A4-81

Public Reading Room

H2-53

RL Docket File (2)

H5-36

Pacific Northwest Laboratory

R. T. Allemann

K7-15

S. A. Bryan

P7-25

B. M. Johnson

$\mathrm{K} 1-78$

M. A. Lilga

P8-38

R. D. Scheele

P7-25

G. F. Schiefelbein

P8-38

D. M. Strachan

K2-38

Hanford Technical Library

P8-55

T. J. Bander

$\mathrm{HO}-33$

J. B. Billetdeaux

R2-08

D. C. Board

S $1-57$

G. L. Borsheim

R2-11

R. J. Cash (2)

$\mathrm{R} 2-78$

M. D. Crippen

L.5-31

G. M. Christensen

H4-21

D. R. Dickinson

L5-31

G. T. Dukelow

R2-78

C. J. Forbes

R 1-08

J. C. Fulton

R2-31

J. M. Grigsby

H4-62

B. M. Hanlon

R $1-80$

H. D. Harmon

R? -52

J. M. Held

R3-09 
DISTRIBUTION (Continued)

Number of Copies

ONSITE

Westinghouse Hanford Company (continued)

M. N. Islam

R3-08

D. W. Jeppson

L5-31

N. W. Kirch

R2-11

W. L. Knecht

$\mathrm{H} 0-34$

C. A. Kuhlman

B3-30

M. Kummerer

H4-62

J. D. McCormack

L5-31

J. M. McLaren

$\mathrm{H} 0-34$

J. E. Meacham

R2-78

N. J. Milliken

H4 -62

S. R. Moreno

B3-06

A. F. Noon

R2-12

R. S. Pop;

R $1-30$

D. A. Rey.

R2-11

F. R. Reich

L5-63

C. P. Schroeder

L7-06

B. C. Simpson

R2-12

J. P. Summerhays

R2-85

H. Toffer

H0-38

W. T. Watson

$\mathrm{H} 0-38$

W. D. Winkelman

L5-55

D. $I$ Wodrich

HO-30

D. D. Wodrich

R2-85

W. F. Zuroff

R2-14

Central Files

L8-04

EDMC

it6-08

Information Release Administration

R1-05

TFIC

R $1-20$ 
This page intentionally left blank. 


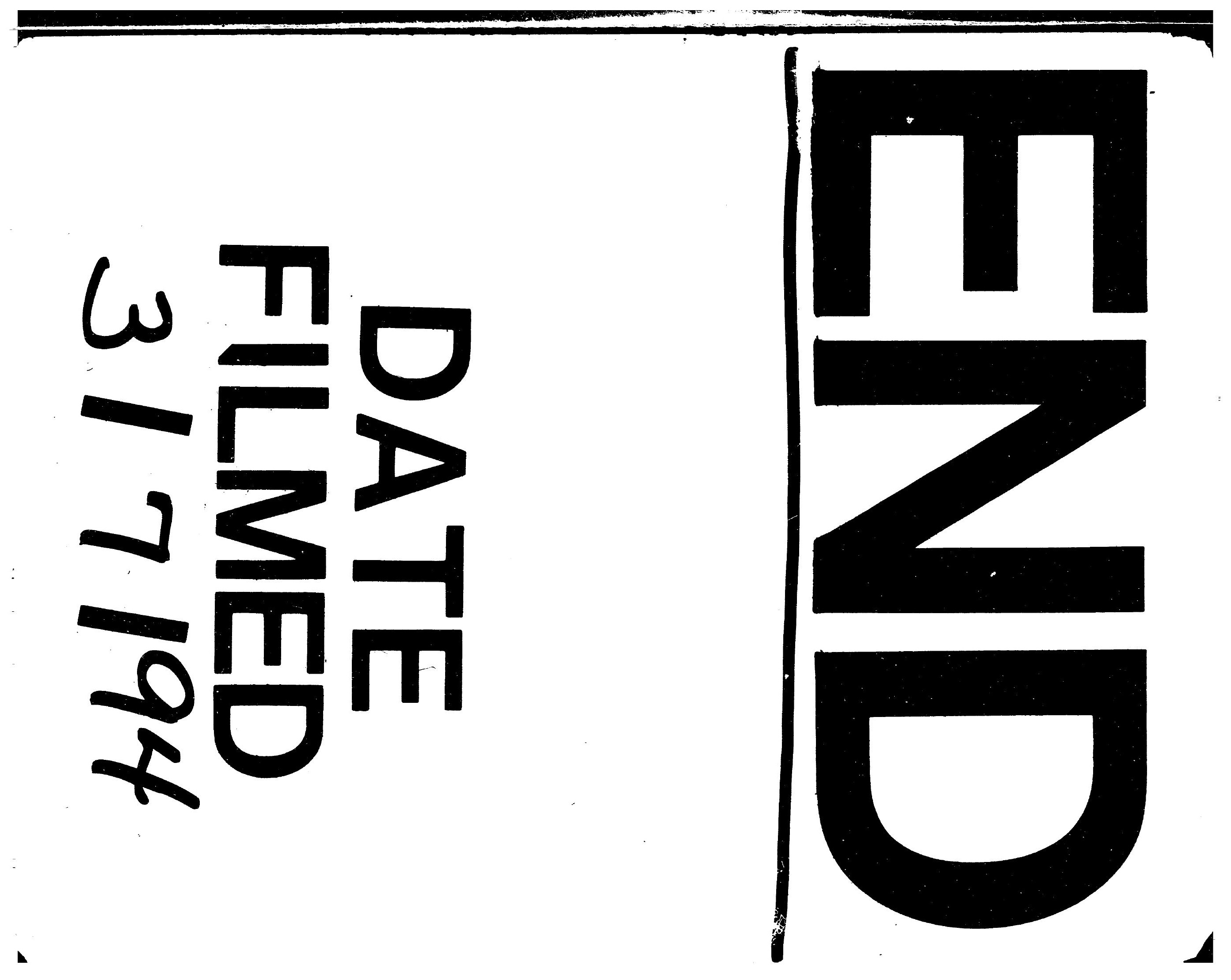


